\title{
Solvent-Driven P-S vs P-C Bond Formation from a Diplatinum(III) Complex and Sulfur-Based Anions
}

\author{
Consuelo Fortuño* and Antonio Martín \\ Departamento de Química Inorgánica, Instituto de Síntesis Química y Catálisis \\ Homogénea-ISQCH, Universidad de Zaragoza-C.S.I.C., E-50009 Zaragoza, Spain. \\ Piero Mastrorilli*, Vito Gallo and Stefano Todisco \\ DICATECh, Politecnico di Bari, I-70125 Bari, Italy
}

Dedicated to Prof. Juan Fornies, on occasion of his $70^{\text {th }}$ birthday

\section{ABSTRACT}

The outcome of the reaction of the $\mathrm{Pt}(\mathrm{III}), \mathrm{Pt}(\mathrm{III})$ complex $\left[\left(\mathrm{C}_{6} \mathrm{~F}_{5}\right)_{2} \mathrm{Pt}^{\mathrm{III}}(\mu-\right.$ $\left.\left.\mathrm{PPh}_{2}\right)_{2} \mathrm{Pt}^{\mathrm{III}}\left(\mathrm{C}_{6} \mathrm{~F}_{5}\right)_{2}\right](\mathrm{Pt}-\mathrm{Pt})$ (1) with the S-based anions thiophenoxide $\left(\mathrm{PhS}^{-}\right)$, ethyl xanthogenate $\left(\mathrm{EtOCS}_{2}{ }^{-}\right)$, 2-mercaptopyrimidinate $\left(\mathrm{pymS}^{-}\right.$) and 2-mercaptopyridinate (pyS ${ }^{-}$) was found dependent on the reaction solvent. The reactions carried out in acetone led to the formation of $\left[\mathrm{N}^{\mathrm{n}} \mathrm{Bu}_{4}\right]\left[\left(\mathrm{R}_{\mathrm{F}}\right)_{2} \mathrm{Pt}^{\mathrm{II}}\left(\mu-\mathrm{PhS}-\mathrm{PPh}_{2}\right)\left(\mu-\mathrm{PPh}_{2}\right) \mathrm{Pt}^{\mathrm{II}}\left(\mathrm{R}_{\mathrm{F}}\right)_{2}\right]$ (2), $\left[\mathrm{N}^{\mathrm{n}} \mathrm{Bu}_{4}\right]\left[\left(\mathrm{R}_{\mathrm{F}}\right)_{2} \mathrm{Pt}^{\mathrm{II}}\left(\mu-\mathrm{EtOCS}_{2}-\mathrm{PPh}_{2}\right)\left(\mu-\mathrm{PPh}_{2}\right) \mathrm{Pt}^{\mathrm{II}}\left(\mathrm{R}_{\mathrm{F}}\right)_{2}\right] \quad(3), \quad\left[\mathrm{N}^{\mathrm{n}} \mathrm{Bu}_{4}\right]\left[\left(\mathrm{R}_{\mathrm{F}}\right)_{2} \mathrm{Pt}^{\mathrm{II}}(\mu-\mathrm{pymS}-\right.$ $\left.\left.\mathrm{PPh}_{2}\right)\left(\mu-\mathrm{PPh}_{2}\right) \mathrm{Pt}^{\mathrm{II}}\left(\mathrm{R}_{\mathrm{F}}\right)_{2}\right]$ (4) or $\left[\mathrm{N}^{\mathrm{n}} \mathrm{Bu}_{4}\right]\left[\left(\mathrm{R}_{\mathrm{F}}\right)_{2} \mathrm{Pt}^{\mathrm{II}}\left(\mu-\mathrm{pyS}-\mathrm{PPh}_{2}\right)\left(\mu-\mathrm{PPh}_{2}\right) \mathrm{Pt}^{\mathrm{II}}\left(\mathrm{R}_{\mathrm{F}}\right)_{2}\right]$ (5), respectively $\left(\mathrm{R}_{\mathrm{F}}=\mathrm{C}_{6} \mathrm{~F}_{5}\right)$. Complexes 2-5 display new $\mathrm{Ph}_{2} \mathrm{P}(\mathrm{SL})$ ligands exhibiting a $\kappa^{2}$ $P, S$ bridging coordination mode, which derive from a reductive elimination of a $\mathrm{PPh}_{2}$ group and the S-based anion. Carrying out the reaction in dichloromethane afforded, in the cases of EtOCS ${ }_{2}^{-}$and $\mathrm{pymS}^{-}$monobridged complexes $\left[\mathrm{N}^{\mathrm{n}} \mathrm{Bu}_{4}\right]\left[\left(\mathrm{PPh}_{2} \mathrm{R}_{\mathrm{F}}\right)\left(\mathrm{R}_{\mathrm{F}}\right)_{2} \mathrm{Pt}^{\mathrm{II}}(\mu-\right.$ $\left.\left.\mathrm{PPh}_{2}\right) \mathrm{Pt}^{\mathrm{II}}\left(\mathrm{EtOCS}_{2}\right)\left(\mathrm{R}_{\mathrm{F}}\right)\right](6)$ and $\left[\mathrm{N}^{\mathrm{n}} \mathrm{Bu}_{4}\right]\left[\left(\mathrm{PPh}_{2} \mathrm{R}_{\mathrm{F}}\right)\left(\mathrm{R}_{\mathrm{F}}\right)_{2} \mathrm{Pt}^{\mathrm{II}}\left(\mu-\mathrm{PPh}_{2}\right) \mathrm{Pt}^{\mathrm{II}}(\mathrm{pymS})\left(\mathrm{R}_{\mathrm{F}}\right)\right](7)$, respectively, which derive from a reductive elimination of a $\mathrm{PPh}_{2}$ group with a pentafluorophenyl ring. The reaction of $\mathbf{1}$ with $\mathrm{EtOCS}_{2} \mathrm{~K}$ in acetonitrile yielded a mixture of $\mathbf{3}$ and $\mathbf{6}$ as a consequence of the concurrence of two processes: $a$ ) the formation of $\mathbf{3}$ by a reaction that parallels the formation of $\mathbf{3}$ by $\mathbf{1}$ plus $\mathrm{EtOCS}_{2} \mathrm{~K}$ in acetone; $b$ ) the transformation of $\mathbf{1}$ into the neutral complex $\left[\left(\mathrm{PPh}_{2} \mathrm{R}_{\mathrm{F}}\right)\left(\mathrm{CH}_{3} \mathrm{CN}\right)\left(\mathrm{R}_{\mathrm{F}}\right) \mathrm{Pt}^{\mathrm{II}}\left(\mu-\mathrm{PPh}_{2}\right) \mathrm{Pt}^{\mathrm{II}}\left(\mathrm{R}_{\mathrm{F}}\right)_{2}\left(\mathrm{CH}_{3} \mathrm{CN}\right)\right]$ (8), which, on turn, reacts with EtOCS $_{2} \mathrm{~K}$ to give $\mathbf{6}$. The $\mathbf{1}$ to $\mathbf{8}$ transformation was found to be fully reversible. In fact, dissolving $\mathbf{8}$ in acetone or dichloromethane afforded pure $\mathbf{1}$ after solvent evaporation or 
crystallisation with $n$-hexane. The XRD structures of 2, 3, 4, 6, 7 and 8 were determined and the behaviour in solution of the new complexes is discussed.

\section{INTRODUCTION}

The chemistry of Pd and Pt in high oxidation states (III and IV) has attracted much attention in the last years. The synthesis of these derivatives is usually achieved through oxidation of $\mathrm{M}(\mathrm{II})$ ( $\mathrm{M}=\mathrm{Pd}$, Pt throughout this paper) centres to six-coordinate octahedral $\mathrm{M}(\mathrm{III})$ or $\mathrm{M}(\mathrm{IV})$ complexes. The reactivity of these oxidised species is almost invariably dominated by reductive elimination processes involving the coupling of two anionic ligands, rendering new square planar $\mathrm{M}(\mathrm{II})$ complexes. This $\mathrm{M}(\mathrm{II}) / \mathrm{M}(\mathrm{IV}) / \mathrm{M}(\mathrm{II})$ strategy is exploited both in stoichiometric synthesis and in catalytic transformations. ${ }^{1-8}$

In the course of our research on diphenylphosphanido derivatives of palladium and platinum we have described, along with several examples of M(II) based species, a number of complexes in which the formal metal oxidation states are III and IV (Scheme 1). ${ }^{9-15}$ Such M(III),M(III) and M(II),M(IV) complexes represent, to the best of our knowledge, the only examples of phosphanido complexes with Pd and Pt in high oxidation state reported to date.

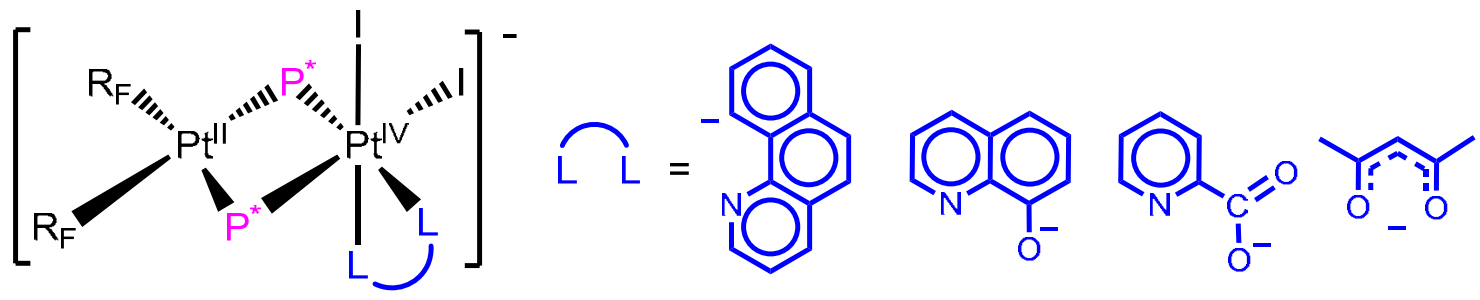

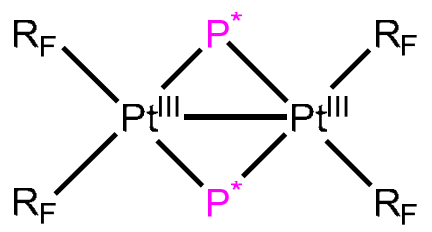

Formal oxidation state of each platinum centre: +3

Total valence electron count: 30

Coordination environment of platinum(III): square-planar 1

$\mathrm{P}^{*}=\mathrm{PPh}_{2}$

$\mathrm{R}_{\mathrm{F}}=\mathrm{C}_{6} \mathrm{~F}_{5}$

Scheme 1. Diphenylphosphanido complexes in which the formal metal oxidation state are III and IV.

In particular, we have prepared the mixed valence dinuclear $\mathrm{Pt}(\mathrm{II}), \mathrm{Pt}(\mathrm{IV})$ complexes $\left[\mathrm{N}^{\mathrm{n}} \mathrm{Bu}_{4}\right]\left[\left(\mathrm{R}_{\mathrm{F}}\right)_{2} \mathrm{Pt}^{\mathrm{II}}\left(\mu-\mathrm{PPh}_{2}\right)_{2} \mathrm{Pt}^{\mathrm{IV}}\left(\mathrm{L}_{2}\right)(\mathrm{I})_{2}\right]\left(\mathrm{R}_{\mathrm{F}}=\mathrm{C}_{6} \mathrm{~F}_{5}\right)$ where $\mathrm{L}_{2}^{-}$is an anionic bidentate 
ligand such as benzoquinolinate $\left(\mathrm{C}^{\wedge} \mathrm{N}\right)$, 8-hydroxyquinolinate $\left(\mathrm{N}^{\wedge} \mathrm{O}\right)$, o-picolinate $\left(\mathrm{N}^{\wedge} \mathrm{O}\right)$ and acetylacetonate $\left(\mathrm{O}^{\wedge} \mathrm{O}\right) .{ }^{13-16}$ Among these derivatives, only the benzoquinolinate complex $\left[\mathrm{N}^{\mathrm{n}} \mathrm{Bu}_{4}\right]\left[\left(\mathrm{R}_{\mathrm{F}}\right)_{2} \mathrm{Pt}^{\mathrm{II}}\left(\mu-\mathrm{PPh}_{2}\right)_{2} \mathrm{Pt}^{\mathrm{IV}}\left(\mathrm{C}^{\wedge} \mathrm{N}\right)(\mathrm{I})_{2}\right]$ was stable enough to be isolated and characterized by XRD. ${ }^{13}$ All these dinuclear Pt(II),Pt(IV) complexes evolve through the coupling of two formally anionic ligands bonded to the platinum(IV) centre with formation of new $\mathrm{P}-\mathrm{C}$ or $\mathrm{P}-\mathrm{O}$ bonds. ${ }^{13-16}$

The first phosphanido platinum(III) complex, $\left[\left(\mathrm{R}_{\mathrm{F}}\right)_{2} \mathrm{Pt}^{\mathrm{III}}\left(\mu-\mathrm{PPh}_{2}\right)_{2} \mathrm{Pt}^{\mathrm{III}}\left(\mathrm{R}_{\mathrm{F}}\right)_{2}\right](P t-P t)\left(\mathrm{R}_{\mathrm{F}}=\right.$ $\mathrm{C}_{6} \mathrm{~F}_{5}$ ), $\mathbf{1}$, was isolated in our laboratory and reported in $1999 .{ }^{9}$ This complex is quite remarkable since, differently from the majority of other Pt(III) complexes which are octahedral, displays a square planar geometry around platinum. In $\mathbf{1}$ both metals are joined by two $\mathrm{PPh}_{2}$ bridging groups and a platinum-platinum bond, as expected for a 30 VEC compound.

In order to explore the possibility of synthesizing $\mathrm{Pt}(\mathrm{II}), \mathrm{Pt}(\mathrm{IV})$ mixed valence dinuclear phosphanido complexes with a six-coordinate octahedral platinum(IV) centre we have reacted halides or pseudohalides with complex 1. However, such reactions led to new dinuclear platinum(II) complexes which are the products of the reductive coupling between: a) a $\mathrm{PPh}_{2}$ group and a $\mathrm{C}_{6} \mathrm{~F}_{5}$ group bonded to the metal centre in the starting material; or b) a $\mathrm{PPh}_{2}$ ligand and the incoming pseudohalides $\mathrm{N}_{3}^{-}$or $\mathrm{OH}^{-}$, i.e., with formation of $\mathrm{P}-\mathrm{C}$ bond or $\mathrm{P}-\mathrm{N}$ and $\mathrm{P}-\mathrm{O}$ bond, respectively. ${ }^{17}$ It is noteworthy that in these reductive eliminations the $\mathrm{P}$ atom forms a bond with a second period element $(\mathrm{C}$, $\mathrm{N}$ or $\mathrm{O})$.

In order to investigate the reactivity of high oxidation state Pt species with bidentate ligands able to coordinate to the platinum centre as chelating ligands, thus potentially facilitating the stabilization of six-coordinate Pt(IV) complexes, we have studied the reaction of the $\mathrm{Pt}(\mathrm{III}), \mathrm{Pt}(\mathrm{III})$ complex 1 with the S-based anions thiophenoxide $\left(\mathrm{PhS}^{-}\right)$, ethyl xanthogenate $\left(\mathrm{EtOCS}_{2}^{-}\right)$, 2-mercaptopyrimidinate $\left(\mathrm{pymS}^{-}\right)$and 2mercaptopyridinate ( $\mathrm{pyS}^{-}$). The reactions carried out in acetone led to the formation of a new $\mathrm{P}-\mathrm{S}$ bond between a $\mathrm{PPh}_{2}$ group and the S-based reactant. Carrying out the reaction in dichloromethane afforded, in the cases of $\mathrm{EtOCS}_{2}^{-}$and $\mathrm{pymS}^{-}$, monobridged complexes in which a $\mathrm{PPh}_{2}$ group was involved in a $\mathrm{P}-\mathrm{C}$ bond formation reaction with a pentafluorophenyl ring and no $\mathrm{P}-\mathrm{S}$ bond formation reaction took place. 


\section{RESULTS}

Reaction of $\left[\left(\mathrm{R}_{\mathrm{F}}\right)_{2} \mathrm{Pt}^{\mathrm{III}}\left(\mu-\mathrm{PPh}_{2}\right)_{2} \mathrm{Pt}^{\mathrm{III}}\left(\mathrm{R}_{\mathrm{F}}\right)_{2}\right](P t-P t) \quad(1)$ with $\mathrm{C}_{6} \mathrm{H}_{5} \mathrm{~S}^{-} \quad\left(\mathrm{PhS}^{-}\right)$, $\mathrm{CH}_{3} \mathrm{CH}_{2} \mathrm{OCS}_{2}^{-}\left(\mathrm{EtOCS}_{2}^{-}\right), \mathrm{C}_{4} \mathrm{H}_{3} \mathrm{~N}_{2} \mathrm{~S}^{-}$(pymS) and $\mathrm{C}_{5} \mathrm{H}_{4} \mathrm{NS}^{-}$(pyS) in acetone. The addition of $\left[\mathrm{N}^{\mathrm{n}} \mathrm{Bu}_{4}\right][\mathrm{PhS}]\left(1: 1\right.$ mixture of $\mathrm{N}^{\mathrm{n}} \mathrm{Bu}_{4} \mathrm{OH}$ and $\mathrm{C}_{6} \mathrm{H}_{5} \mathrm{SH}$ in methanol) to a yellow acetone solution of the Pt(III),Pt(III) complex 1 (1:1 molar ratio) resulted, after work up of the mixture, in the isolation of the platinum(II) derivative $\left[\mathrm{N}^{\mathrm{n}} \mathrm{Bu}_{4}\right]\left[\left(\mathrm{R}_{\mathrm{F}}\right)_{2} \mathrm{Pt}^{\mathrm{II}}\left(\mu-\mathrm{PhS}-\mathrm{PPh}_{2}\right)\left(\mu-\mathrm{PPh}_{2}\right) \mathrm{Pt}^{\mathrm{II}}\left(\mathrm{R}_{\mathrm{F}}\right)_{2}\right]$ (2) (Scheme 2). The synthesis of 2 entails the formation of a P-S bond through the reductive coupling of the coordinated diphenylphosphanide and phenylsulfide.

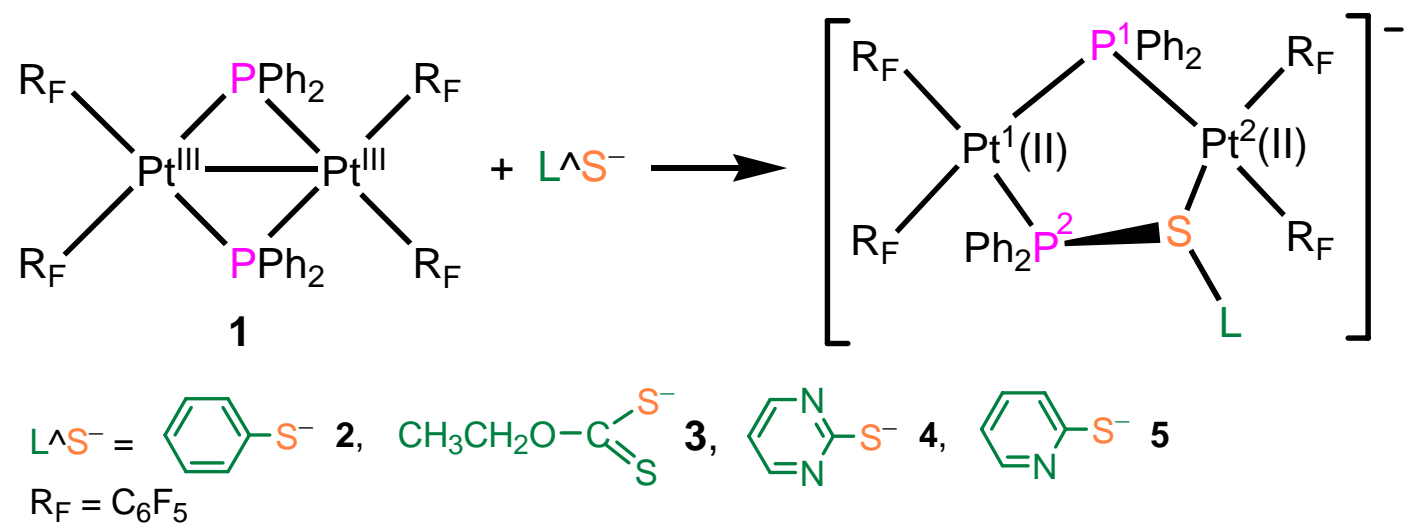

Scheme 2. Reaction of $\mathbf{1}$ with S-based anions in acetone solution.

The addition of potassium ethyl xanthogenate, $\mathrm{KEtOCS}_{2}$, tetra- ${ }^{\mathrm{n}}$ butylammonium 2mercaptopyrimidinate $\left(\left[\mathrm{N}^{\mathrm{n}} \mathrm{Bu}_{4}\right][\mathrm{pymS}], 1: 1\right.$ mixture of $\mathrm{N}^{\mathrm{n}} \mathrm{Bu}_{4} \mathrm{OH}$ and $\mathrm{C}_{4} \mathrm{H}_{3} \mathrm{~N}_{2} \mathrm{SH}$ in methanol) or tetra- ${ }^{n}$ butylammonium 2-mercaptopyridinate ([ $\left.\mathrm{NBu}_{4}\right][\mathrm{pyS}], 1: 1$ mixture of $\mathrm{N}^{\mathrm{n}} \mathrm{Bu}_{4} \mathrm{OH}$ and $\mathrm{C}_{5} \mathrm{H}_{4} \mathrm{NSH}$ in methanol) to an acetone solution of the $\mathrm{Pt}(\mathrm{III}), \mathrm{Pt}(\mathrm{III})$ complex 1 (1:1 molar ratio) gave rise to the analogous platinum(II) derivatives $\left[\mathrm{N}^{\mathrm{n}} \mathrm{Bu}_{4}\right]\left[\left(\mathrm{R}_{\mathrm{F}}\right)_{2} \mathrm{Pt}^{\mathrm{II}}\left(\mu-\mathrm{EtOCS}_{2}-\mathrm{PPh}_{2}\right)\left(\mu-\mathrm{PPh}_{2}\right) \mathrm{Pt}^{\mathrm{II}}\left(\mathrm{R}_{\mathrm{F}}\right)_{2}\right] \quad(3), \quad\left[\mathrm{N}^{\mathrm{n}} \mathrm{Bu}_{4}\right]\left[\left(\mathrm{R}_{\mathrm{F}}\right)_{2} \mathrm{Pt}^{\mathrm{II}}(\mu-\mathrm{pymS}-\right.$ $\left.\left.\mathrm{PPh}_{2}\right)\left(\mu-\mathrm{PPh}_{2}\right) \mathrm{Pt}^{\mathrm{II}}\left(\mathrm{R}_{\mathrm{F}}\right)_{2}\right]$ (4) or $\left[\mathrm{N}^{\mathrm{n}} \mathrm{Bu}_{4}\right]\left[\left(\mathrm{R}_{\mathrm{F}}\right)_{2} \mathrm{Pt}^{\mathrm{II}}\left(\mu-\mathrm{PyS}-\mathrm{PPh}_{2}\right)\left(\mu-\mathrm{PPh}_{2}\right) \mathrm{Pt}^{\mathrm{II}}\left(\mathrm{R}_{\mathrm{F}}\right)_{2}\right]$ (5), respectively (Scheme 2) isolated as pale yellow (3) or white $(\mathbf{4}, \mathbf{5})$ crystals. In all cases the two metal centres exhibit a +2 formal oxidation state and are bridged by a phosphanido and a new neutral thiodiphenylphosphane ligand, $\mathrm{PPh}_{2} \mathrm{SL}$, formed as a consequence of the coupling between a bridging phosphanido and the anion of the added salt. It is apparent that the reactivity of acetone solutions of $\mathbf{1}$ with either monodentate $\left(\mathrm{PhS}^{-}\right)$or bidentate $\left(\mathrm{EtOCS}_{2}{ }^{-}, \mathrm{pymS}^{-}, \mathrm{pyS}^{-}\right) \mathrm{S}$-donor ligands is the same, pointing out that the $\mathrm{L}$ part of the $\mathrm{L}^{\wedge} \mathrm{S}^{-}$reactant behaves as a spectator. 
The elimination reduction processes in hexa-coordinate Pt(IV) complexes, as well as in Pd(IV) ones, are known to pass through the loss of a ligand to generate a fivecoordinate intermediate as preliminary step ${ }^{18-24}$ and five-coordinate $\mathrm{Pt}(\mathrm{IV})$ complexes are now well recognized species. ${ }^{25-32}$ The synthesis of complexes 2-5 can be envisaged to start with the coordination of a good nucleophile, the $\mathrm{L}^{\wedge} \mathrm{S}^{-}$anion, to one of the $\mathrm{Pt}(\mathrm{III})$ centres affording a formally $\mathrm{Pt}(\mathrm{II}), \mathrm{Pt}(\mathrm{IV})$ unsaturated complex in which the $\mathrm{L}^{\wedge} \mathrm{S}^{-}$ligand is terminally bonded to $\mathrm{Pt}(\mathrm{IV})$. The reductive coupling between a bridging diphenylphosphanido and the organic sulfide on the Pt(IV) centre (breakdown of $\mathrm{Pt}^{\mathrm{IV}}-\mathrm{P}$ and $\mathrm{Pt}^{\mathrm{IV}}-\mathrm{S}$ bonds) can form the new $\mathrm{PPh}_{2} \mathrm{SL}$ group while one of the initial two pairs of non-bonding electrons of the $\mathrm{S}$ centre can give rise to a new $\mathrm{Pt}^{\mathrm{II}}-\mathrm{S}$ bond.

The formation of P-S bond from coordinated diorganophosphanide and an S based reactant is well known. ${ }^{33,34}$ Recently, a reversible intramolecular $\mathrm{P}-\mathrm{S}$ bond formation/cleavage mediated by a $\mathrm{Ni}(0) / \mathrm{Ni}(\mathrm{II})$ system has been reported. ${ }^{35}$ However, to the best of our knowledge, all described cases result in complexes featuring a terminally bonded thiophosphane. On the contrary, reaction of $\mathbf{1}$ with $\mathrm{L}^{\wedge} \mathrm{S}^{-}$anions affords complexes in which the formed $\mathrm{Ph}_{2} \mathrm{P}(\mathrm{SL})$ ligands exhibit a $\kappa^{2}-P, S$ bridging coordination mode. A complex featuring a $\mu_{3}-\mathrm{SPPh}_{2}$ ligand has been proposed, on the basis of spectroscopic data as the product of treatment of $\left[\mathrm{Co}_{2} \mathrm{Fe}\left(\mu_{3}-\mathrm{S}\right)\left(\mu-\mathrm{PPh}_{2}\right)_{2}(\mathrm{CO})_{6}\right]$ with 70 atm of $\mathrm{CO}$ at $423 \mathrm{~K}^{36}$

Complexes 2-5 were characterized by elemental analysis, HRMS, XRD, IR and multinuclear NMR spectroscopy. The HRMS(-) analysis of the anionic complexes 2-5 showed the expected peaks with an isotope pattern superimposable to that calculated on the basis of the proposed formula. Figure 1 shows the HRMS(-) spectrogram of 4. 


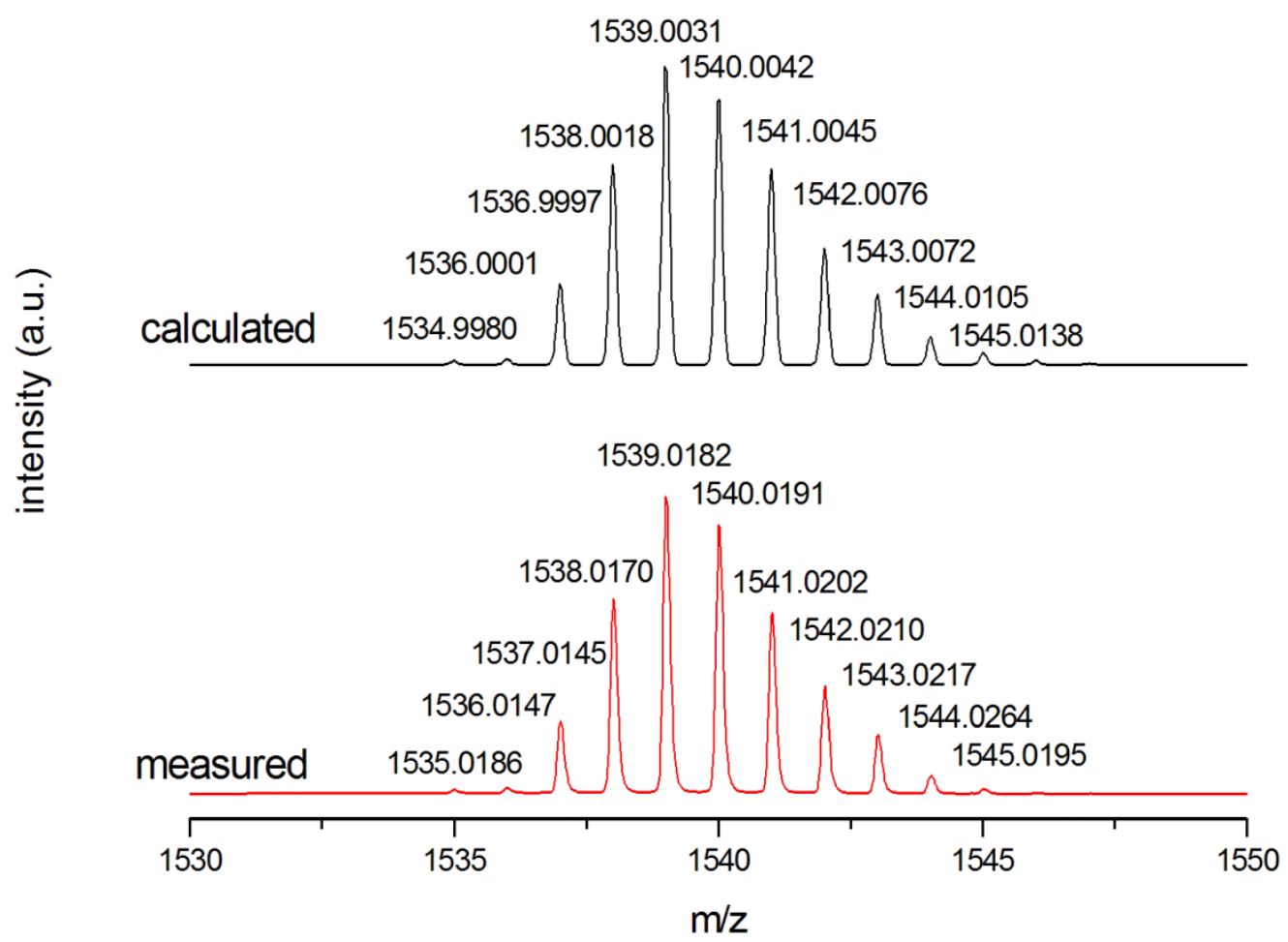

Figure 1. HRMS(-) spectrogram of $\mathbf{4}$ in acetonitrile showing the peak corresponding to the anion $\left[\left(\mathrm{C}_{6} \mathrm{~F}_{5}\right)_{2} \mathrm{Pt}\left(\mu-\mathrm{PPh}_{2}\right)\left\{\kappa^{2} P, S-\mu-\mathrm{P}(\mathrm{S}-\mathrm{pym}) \mathrm{Ph}_{2}\right\} \mathrm{Pt}\left(\mathrm{C}_{6} \mathrm{~F}_{5}\right)_{2}\right]^{-}$. The error between calculated and observed isotopic patterns is $9.3 \mathrm{ppm}$.

The IR spectra of complexes 2-5 in the solid state confirm the presence of the relevant ligands and, although they are not particularly informative, it is to note that the band of the $\mathrm{C}_{6} \mathrm{~F}_{5}$ group which appears at $964 \mathrm{~cm}^{-1}$ for the $\mathrm{Pt}(\mathrm{III})$ precursor $\mathbf{1},{ }^{9}$ is shifted toward lower wavelengths in the spectra of 2-5, as consequence of the decrease of the formal oxidation states of the metal centres. ${ }^{11,37}$

The ${ }^{31} \mathrm{P}\left\{{ }^{1} \mathrm{H}\right\}$ NMR spectra of $\mathbf{2 - 5}$ in deuteroacetone solution showed two broad singlets flanked by ${ }^{195} \mathrm{Pt}$ satellites. The broadness of the signals is mainly due to unresolved coupling with ${ }^{19} \mathrm{~F}$ atoms, as is common in this type of complexes. ${ }^{12,38,39}$ The signals of the bridging $\mathrm{P}^{1}$ showed the expected two sets of ${ }^{195} \mathrm{Pt}$ satellites. The correct attribution of the ${ }^{1} \mathrm{JP}$,Pt coupling constants was made comparing ${ }^{31} \mathrm{P}$ and ${ }^{195} \mathrm{Pt}$ NMR features. The chemical shift of the of phosphanido-bridged P atom in the starting material 1 ( $\delta$ 281.7) decreased significantly in $2-5$ ( $\delta$ from -12 to -21$)$ due to the change from a " $\mathrm{Pt}^{\mathrm{III}}(\mu$ - 


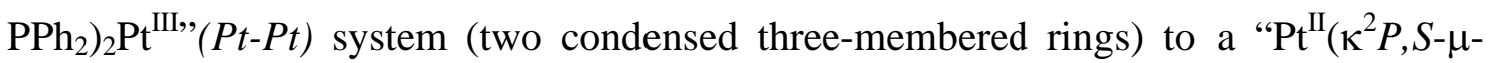
$\mathrm{PS})\left(\mu-\mathrm{PPh}_{2}\right) \mathrm{Pt}^{\mathrm{II}}$ fragment (a five-membered ring). ${ }^{39-42}$ The $\mathrm{P}$ signalls of the $\kappa^{2} P, S$ thiophosphano ligands in 2-5 were found between $\delta 101$ and $\delta 107$. The ${ }^{195} \mathrm{Pt}$ NMR features were obtained by carrying out ${ }^{19} \mathrm{~F}-{ }^{195} \mathrm{Pt}$ HMQC experiments, exploiting the couplings between pentafluorophenyl ${ }^{19} \mathrm{~F}$ atoms and each of the ${ }^{195} \mathrm{Pt}$ atoms. Figure 2 shows the ${ }^{19} \mathrm{~F}^{195} \mathrm{Pt}$ HMQC of complex 2 . In all cases, for complexes 2-5, $\mathrm{Pt}^{1}$ resonance fell at ca. $\delta-4500$ while $\mathrm{Pt}^{2}$ resonance was found at ca. $\delta-4300$. Specific ${ }^{195} \mathrm{Pt}$ NMR chemical shifts are reported in the experimental part. The $\mathrm{Pt}^{1}$ chemical shift of $\mathbf{2 - 5}$ is almost identical to that found for $\mathrm{Pt}^{1}$ in the analogous complex $\left[\left(\mathrm{C}_{6} \mathrm{~F}_{5}\right)_{2} \mathrm{Pt}^{1}(\mu-\right.$ $\left.\left.\mathrm{PPh}_{2}\right)\left\{\kappa^{2} \mathrm{P}, \mathrm{O}-\mu-\mathrm{P}(\mathrm{O}) \mathrm{Ph}_{2}\right\} \mathrm{Pt}^{2}\left(\mathrm{C}_{6} \mathrm{~F}_{5}\right)_{2}\right]^{2-}\left(\delta_{\mathrm{Pt} 1}=-4498\right)$, while the $\mathrm{Pt}^{2}$ resonance of 2-5 was found significantly high-field shifted respect to $\mathrm{Pt}^{2}$ of $\left[\left(\mathrm{C}_{6} \mathrm{~F}_{5}\right)_{2} \mathrm{Pt}^{1}\left(\mu-\mathrm{PPh}_{2}\right)\left\{\kappa^{2} \mathrm{P}, \mathrm{O}-\right.\right.$ $\left.\left.\mu-\mathrm{P}(\mathrm{O}) \mathrm{Ph}_{2}\right\} \mathrm{Pt}^{2}\left(\mathrm{C}_{6} \mathrm{~F}_{5}\right)_{2}\right]^{2-} \quad\left(\delta_{\mathrm{Pt} 2}=-3719\right),{ }^{17}$ as a consequence of the lower electronegativity of S compared to $\mathrm{O}$. It is interesting to note that the chemical shift of S-bound ${ }^{195} \mathrm{Pt}$ nuclei for dinuclear complexes of general formula $\left[\left(\mathrm{Pt}_{2}\left\{\kappa^{2} P, S-\mu-\right.\right.\right.$ $\left.\left.\mathrm{P}(\mathrm{S}) \mathrm{R}_{2}\right\}\left\{\mu-\mathrm{L}^{\prime}\right\} \mathrm{L}_{2}\right](P t-P t)$, in which the Pt atoms are linked by a covalent bond, range from -5128 to $-5216 .{ }^{43-46}$ Such values, similar to those of $\mathbf{1},(\delta-5298)$ are consistent with the theory that ${ }^{195} \mathrm{Pt}$ chemical shifts are sensitive to the geometry around the metal more than to the Pt formal oxidation state. ${ }^{41}$

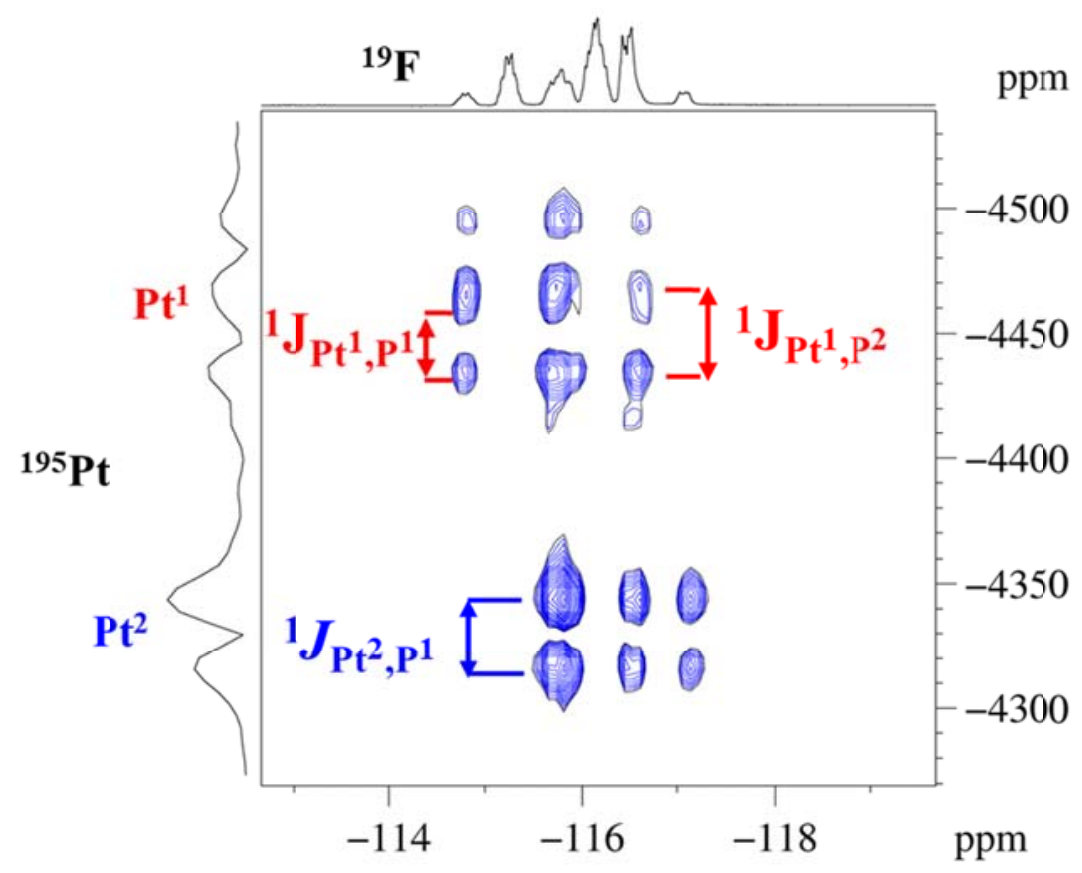

Figure 2. ${ }^{19} \mathrm{~F}-{ }^{195} \mathrm{Pt}$ HMQC of complex 2 (acetone- $d_{6}$, $298 \mathrm{~K}$ ) 
The ${ }^{19} \mathrm{~F}$ NMR spectrum of $\mathbf{2 - 5}$ showed clear signals of the fluorine atoms of the $\mathrm{C}_{6} \mathrm{~F}_{5}$ moieties. Due to slow rotation of the pentafluorophenyl rings, the ortho-F and meta-F nuclei give rise to two (overlapped) signals for each ring. The attributions of the ${ }^{19} \mathrm{~F}$ nuclei to the appropriate $\mathrm{C}_{6} \mathrm{~F}_{5}$ ring reported in the experimental part were made on the basis of ${ }^{19} \mathrm{~F}-{ }^{195} \mathrm{Pt}$ HMQC as well as of ${ }^{19} \mathrm{~F}-\mathrm{NOESY}$ experiments.

The ${ }^{1} \mathrm{H}$ NMR spectrum of 2-5 showed, beside those of the $\left[\mathrm{N}^{\mathrm{n}} \mathrm{Bu}_{4}\right]^{+}$cation, the expected signals for the protons of the coordinated $\mathrm{PPh}_{2}$ and $\mathrm{L}^{\wedge} \mathrm{S}^{-}$ligands. The attribution of all protons for complexes 2-5 was made by combining information deriving from ${ }^{1} \mathrm{H}$ COSY, ${ }^{1} \mathrm{H}-{ }^{31} \mathrm{P}$ HMQC and ${ }^{1} \mathrm{H}$ NOESY experiments at $298 \mathrm{~K}$. Interestingly, the ${ }^{1} \mathrm{H}$ NOESY spectrum of $\mathbf{4}$ and $\mathbf{5}$ (but not of $\mathbf{2}$ and 3) showed the presence of positive cross peaks indicative of chemical exchanges. Such cross peaks correlated all aromatic signals with signals barely detectable in the ${ }^{1} \mathrm{H}$ spectrum, suggesting the occurrence of an equilibrium between 4 (or 5) and an isomer, present in solution in very low amount. The absence of this equilibrium in the cases of complexes 2 and $\mathbf{3}$ suggests that the equilibrium indicated by ${ }^{1} \mathrm{H}$ NOESY experiments of $\mathbf{4}$ and 5 could involve the decoordination of $\mathrm{S}$ and the coordination of $\mathrm{N}$ of the thiopyridine or thiopyrimidine ligands, respectively (Scheme 3). Figure 3 shows a portion of the ${ }^{1} \mathrm{H}$ NOESY spectrum of 5 .

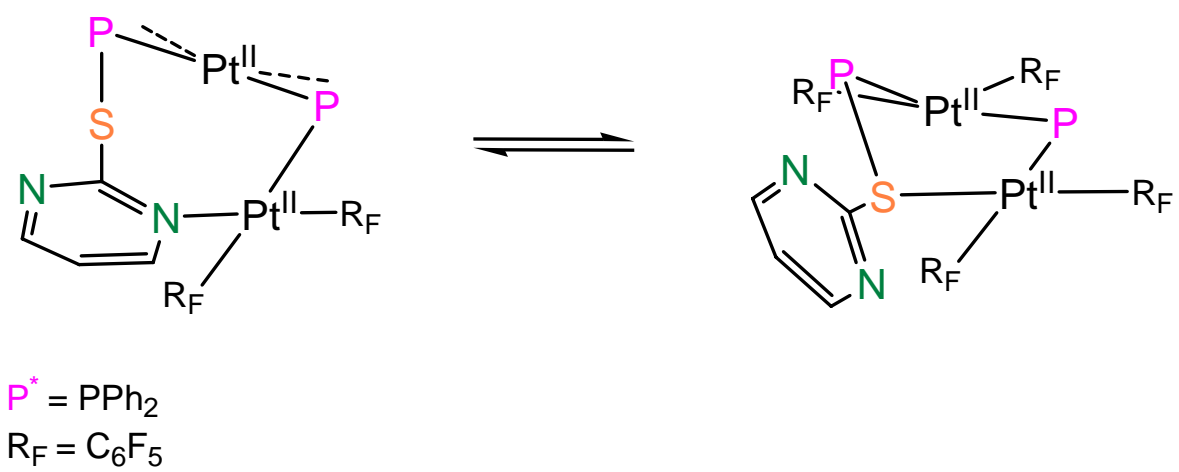

Scheme 3. A plausible equilibrium explaining the exchange cross peaks detected in the ${ }^{1} \mathrm{H}$ NOESY experiments of $\mathbf{4}$ and $\mathbf{5}$. 


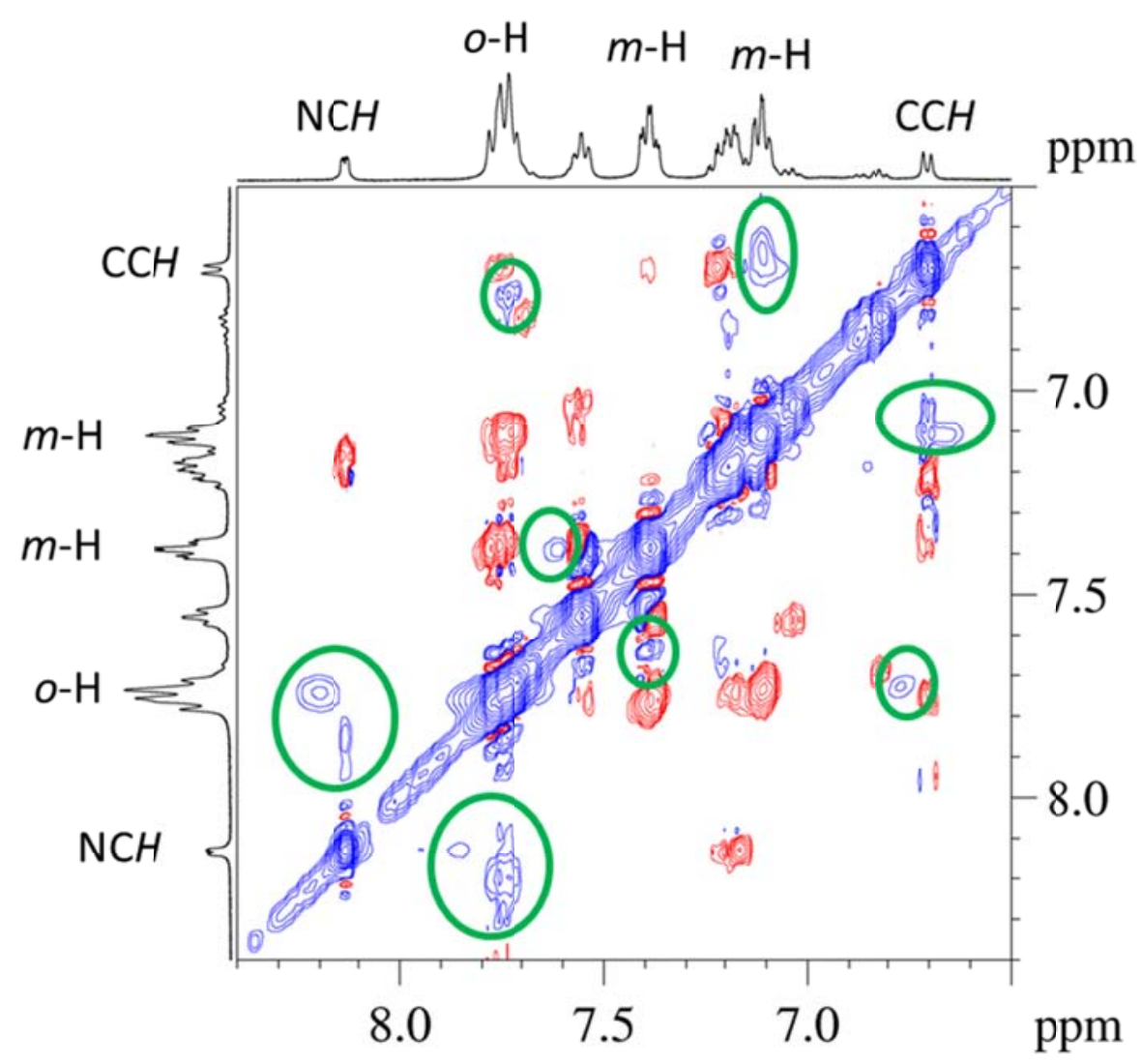

Figure 3. Portion of the ${ }^{1} \mathrm{H}$ NOESY spectrum of 5 (acetone- $d_{6}$, 298 k). Exchange crosspeaks are circled in green.

The structures of complexes $\mathbf{2 - 4}$ were established by X-ray diffraction studies. Crystal data and refinement parameters are given in Table S1 (See Supporting Information). Structures of the complex anions of $\mathbf{2 - 4}$ together with the atom-labelling scheme are shown in Figures 4-6. Selected bond distances and angles are listed in Table S2. 3 presents two complex units in the asymmetric part of the unit cell with very similar structural parameters, and for discussion purposes only the data corresponding to one of them are mentioned here. The three anions of 2-4 are dimetallic complexes in which the two Pt atoms are bridged by diphenylphosphanide and thiophosphano ligands and two pentafluorophenyl groups are bonded as terminal ligands to each metal centre. The Pt atoms lie in the centre of square-planar environments and show in the three anions of 24 very similar bond distances and angles as well as an analogue not planar core. The dihedral angle between the best planes around the two Pt atoms is $28.51(3)^{\circ}$ in 2 , 26.57(6) $)^{\circ}$ in 3 and 28.51(3) $)^{\circ}$ in 4. The $\mathrm{Pt}(1)-\mathrm{P}(1)-\mathrm{Pt}(2)$ angles are broadler, 114.19(5) ${ }^{\circ}$ in 
2, $118.46(7)^{\circ}$ in 3 and $117.45(4)^{\circ}$ in $\mathbf{4}$, than in the $\mathrm{Pt}(\mathrm{III})-\mathrm{Pt}(\mathrm{III})$ starting material $\mathbf{1}$, 73.47(5) ${ }^{\circ}$, which reflects in longer intermetallic separations: 3.910(1), 4.036(1) and 4.024(1) $\AA$, respectively (2.7245(7) $\AA$ in 1). These parameters agree with the change from a dinuclear complex with 30 valence electron count to saturated dinuclear species with 32 valence electron count. The "Pt(1)-P(1)-Pt(2)" fragment has been usually found in our complexes but the " $\mathrm{Pt}(1)-\mathrm{P}(2)-\mathrm{S}-\mathrm{Pt}(2)$ ” one requires a special attention. The new thiophosphano groups $\mathrm{Ph}_{2} \mathrm{P}-\mathrm{SL}\left(\mathrm{L}=\mathrm{Ph}, 2\right.$; $\left.\mathrm{CSOC}_{2} \mathrm{H}_{5}, 3 ; \mathrm{CN}_{2} \mathrm{C}_{3} \mathrm{H}_{3}, 4\right)$ are neutral ligands bonded to two platinum centres in a bridging mode through the $\mathrm{P}$ and $\mathrm{S}$ atoms. These kind of complexes containing a neutral tertiary thiophosphano ligand, $\mathrm{R}_{2} \mathrm{P}-\mathrm{SR}$ 'with a "M-P-S-M") skeleton ( $\mathrm{M}, \mathrm{M}$ ' = any transition metal) has not previously been characterized structurally by X-ray diffraction (CSD version 5.38, updated May 2017). Three entries were found in the CSD for the "Pt-P-S-Pt" skeleton if the two metal centres are linked by a bridging $\mathrm{R}_{2} \mathrm{P}-\mathrm{S}^{-}$thiophosphinate anion. ${ }^{47-49}$ The sulfur atom in 2-4 can be regarded as forming single covalent bonds with a phosphorous and a carbon atoms and donating formally two electrons to the platinum atom, resulting in a pyramidal coordination in agreement with the existence of a lone pair. Nevertheless, the Pt(2)-S distances, as well as the P-S ones, in 2-4 (see Table S2) are not very different from those observed in the reported thiophosphinate complexes in which the sulfur atom establishes two chemical bonds. ${ }^{47-49}$ The pyramidal geometry of the sulfur bridging atom bonded to three different substituents renders such atom chiral.

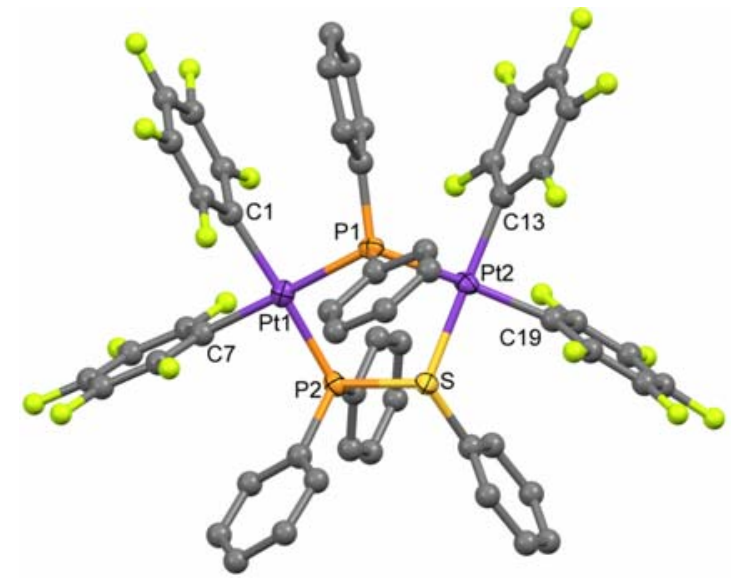

Figure 4. Crystal structure of the anion of complex $\left[\mathrm{N}^{\mathrm{n}} \mathrm{Bu}_{4}\right]\left[\left(\mathrm{R}_{\mathrm{F}}\right)_{2} \mathrm{Pt}^{\mathrm{II}}\left(\mu-\mathrm{PhS}-\mathrm{PPh}_{2}\right)(\mu-\right.$ $\left.\left.\mathrm{PPh}_{2}\right) \mathrm{Pt}^{\mathrm{II}}\left(\mathrm{R}_{\mathrm{F}}\right)_{2}\right]$ (2). Ellipsoids are drawn at their 50\% probability level. Hydrogen atoms have been omitted for clarity. 


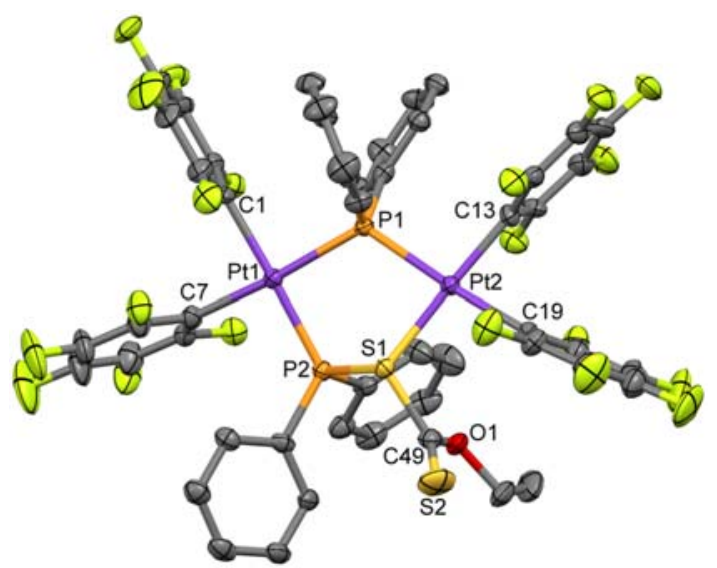

Figure 5. Crystal structure of the anion of complex $\left[\mathrm{N}^{\mathrm{n}} \mathrm{Bu}_{4}\right]\left[\left(\mathrm{R}_{\mathrm{F}}\right)_{2} \mathrm{Pt}^{\mathrm{II}}\left(\mu-\mathrm{EtOCS}_{2}-\right.\right.$ $\left.\left.\mathrm{PPh}_{2}\right)\left(\mu-\mathrm{PPh}_{2}\right) \mathrm{Pt}^{\mathrm{II}}\left(\mathrm{R}_{\mathrm{F}}\right)_{2}\right] \cdot 1.35 \mathrm{CH}_{2} \mathrm{Cl}_{2}\left(3 \cdot 1.35 \mathrm{CH}_{2} \mathrm{Cl}_{2}\right)$. Ellipsoids are drawn at their $50 \%$ probability level. Hydrogen atoms have been omitted for clarity.

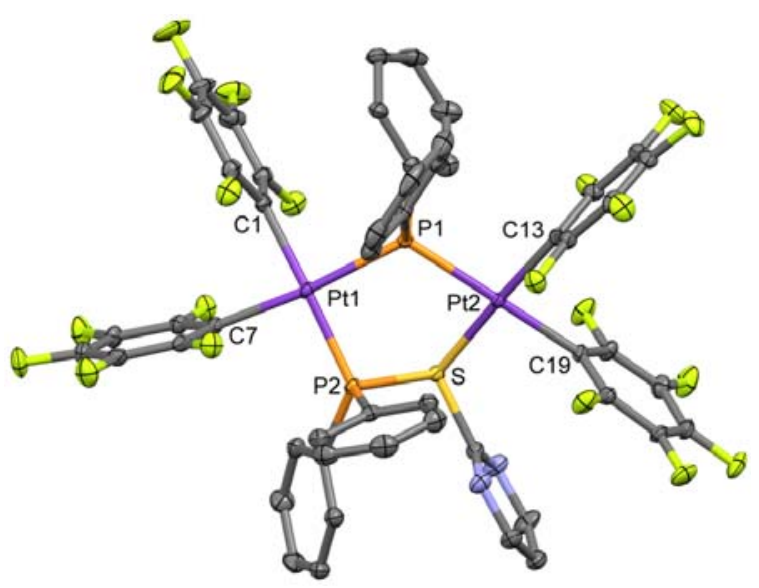

Figure 6. Crystal structure of the anion of complex $\left[\mathrm{N}^{\mathrm{n}} \mathrm{Bu}_{4}\right]\left[\left(\mathrm{R}_{\mathrm{F}}\right)_{2} \mathrm{Pt}^{\mathrm{II}}\left(\mu-\mathrm{pymS}-\mathrm{PPh}_{2}\right)(\mu-\right.$ $\left.\left.\mathrm{PPh}_{2}\right) \mathrm{Pt}^{\mathrm{II}}\left(\mathrm{R}_{\mathrm{F}}\right)_{2}\right] \cdot 1.25 \mathrm{Me}_{2} \mathrm{CO} \quad\left(\mathbf{4} \cdot 1.25 \mathrm{Me}_{2} \mathrm{CO}\right)$. Ellipsoids are drawn at their $50 \%$ probability level. Hydrogen atoms have been omitted for clarity.

\section{Reaction of $\left[\left(\mathrm{R}_{\mathrm{F}}\right)_{2} \mathrm{Pt}^{\mathrm{III}}\left(\mu-\mathrm{PPh}_{2}\right)_{2} \mathrm{Pt}^{\mathrm{III}}\left(\mathrm{R}_{\mathrm{F}}\right)_{2}\right]$ (1) with $\mathrm{C}_{6} \mathrm{H}_{5} \mathrm{~S}^{-}\left(\mathrm{PhS}^{-}\right), \mathrm{CH}_{3} \mathrm{CH}_{2} \mathrm{OCS}_{2}^{-}$ $\left(\right.$ EtOCS $\left._{2}{ }^{-}\right), \mathrm{C}_{4} \mathrm{H}_{3} \mathrm{~N}_{2} \mathrm{~S}^{-}\left(\mathrm{pymS}^{-}\right)$and $\mathrm{C}_{5} \mathrm{H}_{4} \mathrm{NS}^{-}\left(\mathrm{pyS}^{-}\right)$in dichloromethane.}

The addition of the monodentate thiophenoxide anion as the $\left[\mathrm{N}^{\mathrm{n}} \mathrm{Bu}_{4}\right][\mathrm{PhS}]$ salt $(1: 1$ mixture of $\mathrm{N}^{\mathrm{n}} \mathrm{Bu}_{4} \mathrm{OH}$ and $\mathrm{C}_{6} \mathrm{H}_{5} \mathrm{SH}$ in methanol) to a $\mathrm{CH}_{2} \mathrm{Cl}_{2}$ solution of 1 (1:1 molar ratio) afforded complex 2 , the same obtained in acetone solution, as described above. However, the addition of the bidentate anions $\mathrm{EtOCS}_{2}{ }^{-}$and $\mathrm{pymS}^{-}(1: 1$ mixture of $\mathrm{N}^{\mathrm{n}} \mathrm{Bu}_{4} \mathrm{OH}$ and $\mathrm{C}_{4} \mathrm{H}_{3} \mathrm{~N}_{2} \mathrm{SH}$ in methanol) to yellow $\mathrm{CH}_{2} \mathrm{Cl}_{2}$ solutions of $\mathbf{1}$ yielded the 
monobridged diplatinum(II) complexes $\quad\left[\mathrm{N}^{\mathrm{n}} \mathrm{Bu}_{4}\right]\left[\left(\mathrm{PPh}_{2} \mathrm{R}_{\mathrm{F}}\right)\left(\mathrm{R}_{\mathrm{F}}\right)_{2} \mathrm{Pt}^{\mathrm{II}}(\mu-\right.$ $\left.\left.\mathrm{PPh}_{2}\right) \mathrm{Pt}^{\mathrm{II}}\left(\mathrm{EtOCS}_{2}\right)\left(\mathrm{R}_{\mathrm{F}}\right)\right](6)$ and $\left[\mathrm{N}^{\mathrm{n}} \mathrm{Bu}_{4}\right]\left[\left(\mathrm{PPh}_{2} \mathrm{R}_{\mathrm{F}}\right)\left(\mathrm{R}_{\mathrm{F}}\right)_{2} \mathrm{Pt}^{\mathrm{II}}\left(\mu-\mathrm{PPh}_{2}\right) \mathrm{Pt}^{\mathrm{II}}(\mathrm{pymS})\left(\mathrm{R}_{\mathrm{F}}\right)\right](7)$, respectively (Scheme 4). When $\left[\mathrm{N}^{\mathrm{n}} \mathrm{Bu}_{4}\right][\mathrm{pyS}]$, $\left(1: 1\right.$ mixture of $\mathrm{N}^{\mathrm{n}} \mathrm{Bu}_{4} \mathrm{OH}$ and $\mathrm{C}_{5} \mathrm{H}_{4} \mathrm{NSH}$ in methanol) was added to a $\mathrm{CH}_{2} \mathrm{Cl}_{2}$ solution of $\mathbf{1}$ (1:1 molar ratio), a complex mixture of products was obtained (NMR analysis), which was no further characterised.

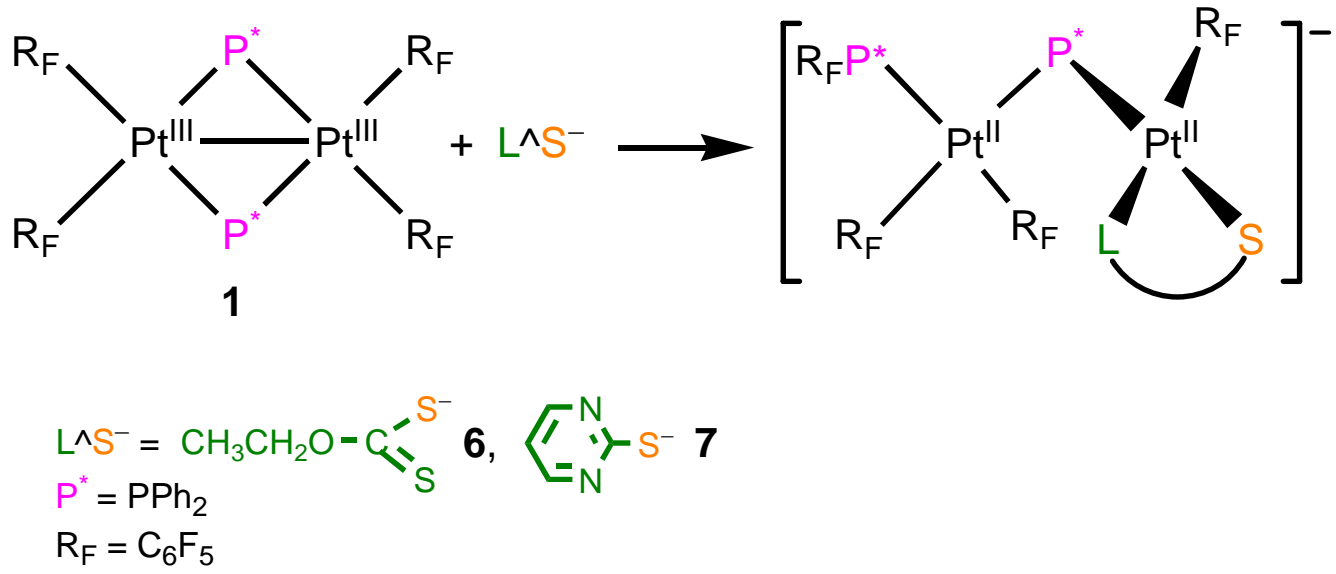

Scheme 4. Reaction of 1 with S-based anions in dichloromethane solution.

Complexes 6-7 were characterized by elemental analysis, HRMS, IR and multinuclear NMR spectroscopy. The structures of complexes $\mathbf{6}$ and $\mathbf{7}$ were established by X-ray diffraction studies. Drawings of the complex anions of $\mathbf{6}$ and $\mathbf{7}$ together with the atomlabelling scheme are shown in Figures 7 and 8. Crystal data and refinement parameters are given in Table S1 (See Supporting Information). Selected bond distances and angles are listed in Table S3.

In complexes $\mathbf{6}$ and $\mathbf{7}$ the two metal centres with formal oxidation state +2 are singly joined by a phosphanido bridging ligand while the added bidentate anion is coordinated to a metal centre as a chelate ligand. The other platinum(II) centre is bonded to a (pentafluorophenyl)diphenylphosphane group, $\mathrm{PPh}_{2} \mathrm{R}_{\mathrm{F}}$, produced by reductive coupling between a bridging $\mathrm{PPh}_{2}$ and a pentafluorophenyl group on the $\mathrm{Pt}(\mathrm{IV})$ metal centre of the alleged Pt(II),Pt(IV) intermediate. ${ }^{11,12,14,50-53}$ The anions of $\mathbf{6}$ and $\mathbf{7}$ are bimetallic complexes formed by two fragments: “( $\left(\mathrm{PPh}_{2} \mathrm{R}_{\mathrm{F}}\right)\left(\mathrm{R}_{\mathrm{F}}\right)_{2} \mathrm{Pt}$ ” and "Pt(EtOCS$\left.{ }_{2}-\kappa^{2}-S, S^{\prime}\right)\left(\mathrm{R}_{\mathrm{F}}\right)$ ” in 6, or "Pt(Spy- $\kappa^{2}-N, S\left(\mathrm{R}_{\mathrm{F}}\right)$ " in 7 , joined through the two platinum centres by a single bridging diphenylphosphanide group. The platinum(II) centres in both fragments lie in distorted square planar environments. The value of $\mathrm{P}(1)-\mathrm{Pt}(1)-\mathrm{P}(2)$ is large, $118.44(3)^{\circ}$ (6) and $117.11(4)^{\circ}(7)$, and the small values of $\mathrm{S}(1)-\mathrm{Pt}(2)-\mathrm{S}(2)$ in $\mathbf{6}, 73.91(3)^{\circ}$, and $\mathrm{S}-$ 
$\operatorname{Pt}(2)-\mathrm{N}(1)$ in $7,68.91(10)^{\circ}$, are the expected ones for the bite angle of the chelating xanthogenate and pyrimidine-2-thiolate ligands. ${ }^{54-61}$ The dihedral angle between the best coordination planes of the two Pt atoms in each complex is $59.56(3)^{\circ}$ and $62.62(3)^{\circ}$ respectively.

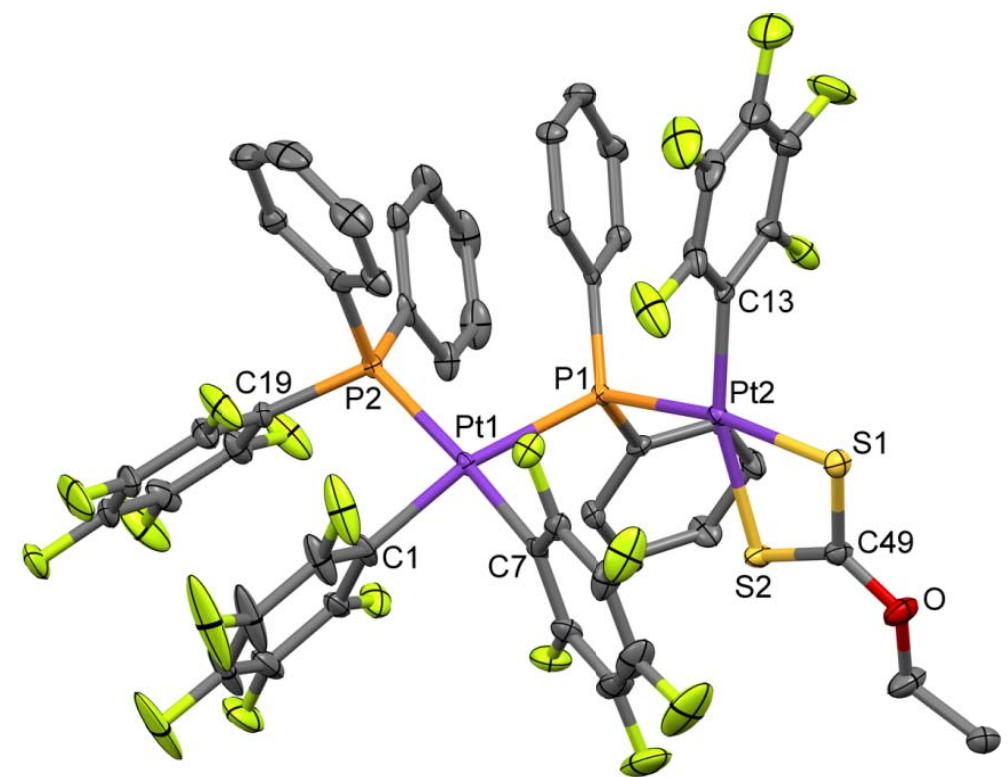

Figure 7. Crystal structure of the anion of complex $\left[\mathrm{NBu}_{4}\right]\left[\left(\mathrm{PPh}_{2} \mathrm{R}_{\mathrm{F}}\right)\left(\mathrm{R}_{\mathrm{F}}\right)_{2} \mathrm{Pt}^{\mathrm{II}}(\mu-\right.$ $\left.\left.\mathrm{PPh}_{2}\right) \mathrm{Pt}^{\mathrm{II}}\left(\mathrm{EtOCS}_{2}\right)\left(\mathrm{R}_{\mathrm{F}}\right)\right]$ (6). Ellipsoids are drawn at their $50 \%$ probability level. Hydrogen atoms have been omitted for clarity.

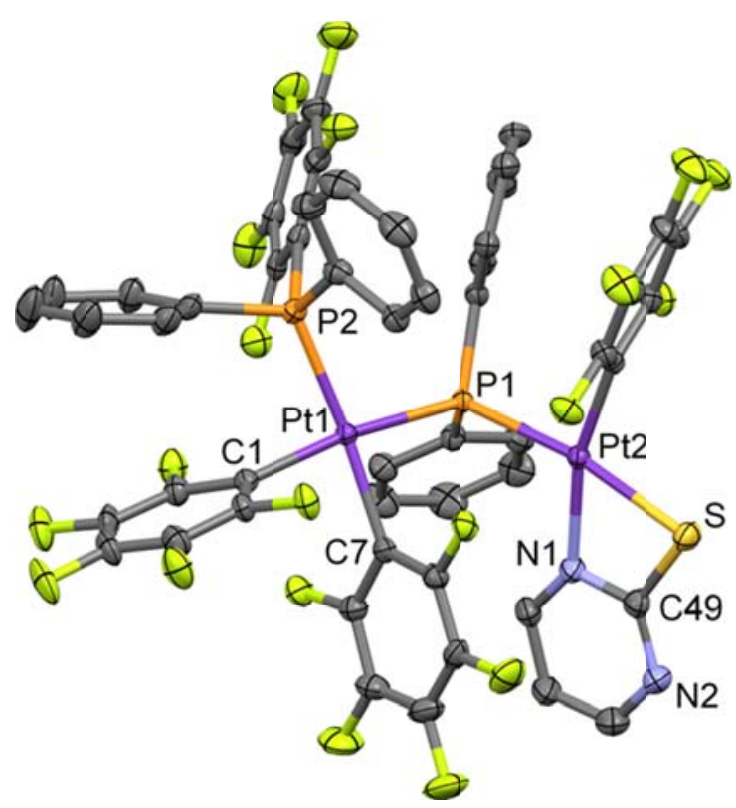


Figure 8. Crystal structure of the anion of complex $\left[\mathrm{N}^{\mathrm{n}} \mathrm{Bu}_{4}\right]\left[\left(\mathrm{PPh}_{2} \mathrm{R}_{\mathrm{F}}\right)\left(\mathrm{R}_{\mathrm{F}}\right)_{2} \mathrm{Pt}^{\mathrm{II}}(\mu-\right.$ $\left.\left.\mathrm{PPh}_{2}\right) \mathrm{Pt}^{\mathrm{II}}(\mathrm{pymS})\left(\mathrm{R}_{\mathrm{F}}\right)\right] \cdot 0.5 n-\mathrm{C}_{6} \mathrm{H}_{14}\left(7 \cdot 0.5 n-\mathrm{C}_{6} \mathrm{H}_{14}\right)$. Ellipsoids are drawn at their $50 \%$ probability level. Hydrogen atoms have been omitted for clarity.

The ${ }^{1} \mathrm{H}$ NMR spectrum at $298 \mathrm{~K}$ of $\mathbf{6}$ shows, beside signals due to the $\left[\mathrm{N}^{\mathrm{n}} \mathrm{Bu}_{4}\right]^{+}$cation, sharp signals due to aromatic $\mathrm{PPh}_{2}$ and aliphatic OEt protons of the coordinated xanthogenate ligand. Conversely, the ${ }^{1} \mathrm{H}$ NMR spectrum of the anion of $\mathbf{7}$ appeared at $298 \mathrm{~K}$ as a very broad signal ranging from 9.0 to $6.0 \mathrm{ppm}$, from which only two signals emerge, at $\delta 8.19$ and $\delta 6.39$, ascribable to the pyrimidine protons. On lowering the temperature (Figure 9) the signals progressively sharpen and at $198 \mathrm{~K}$ the spectrum displays the signals of two interconverting conformers ( ${ }^{1} \mathrm{H}$ EXSY at $198 \mathrm{~K}$ ), one of which (labelled $A$ in Figure 9) much more abundant than the other $(B)$. In the ${ }^{1} \mathrm{H}$ NMR spectrum of the anion of $\mathbf{7}$ at $198 \mathrm{~K}$ were found, beside weak signals attributable to the minor conformer (labelled B in Figure 9), fifteen signals attributable to: the $\mathrm{P}^{2} \mathrm{Ph}_{2}$ (ten signals), the pyrimidine rings (three signals), and only two of the ten signals deriving from $\mathrm{P}\left(\mathrm{C}_{6} \mathrm{~F}_{5}\right) \mathrm{Ph}_{2}$ (presumably the para- $\mathrm{H}$ of the two phenyl rings) with the remaining eight signals of the $\mathrm{P}\left(\mathrm{C}_{6} \mathrm{~F}_{5}\right) \mathrm{Ph}_{2}$ ligand giving an extremely broad peak ranging from 8.0 to 5.5 ppm (see Figure 9). 

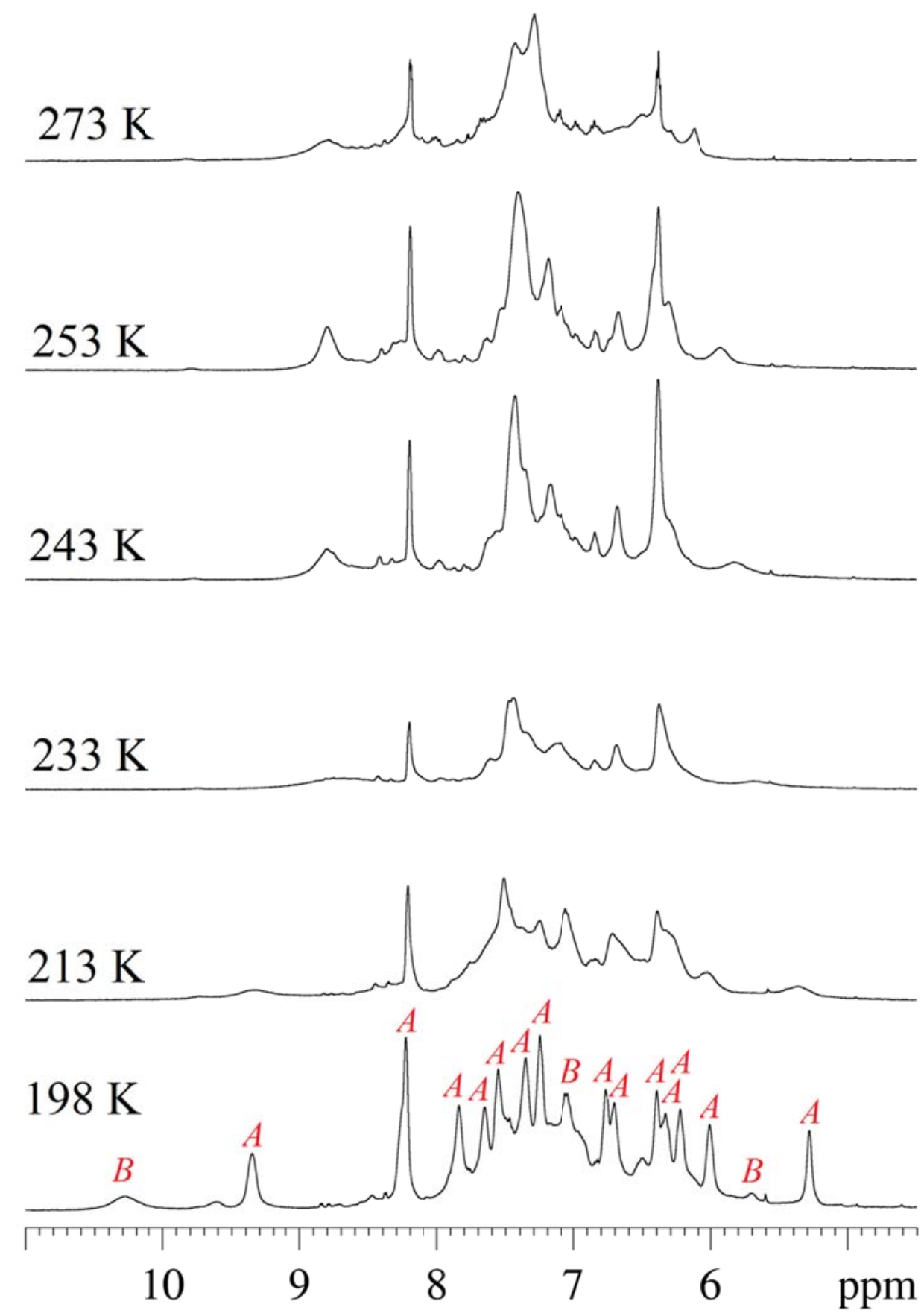

Figure 9. VT ${ }^{1} \mathrm{H}$ NMR spectrum of 7 (acetone- $d_{6}$ ). Only signals of conformer $B$ which are not overlapped with those of $A$ are labelled. 
A behaviour similar to that observed for ${ }^{1} \mathrm{H}$ NMR was observed in ${ }^{19} \mathrm{~F}$ NMR experiments: the ${ }^{19} \mathrm{~F}$ NMR spectrum at $298 \mathrm{~K}$ was extremely broad, while the ${ }^{19} \mathrm{~F}$ NMR spectrum at $198 \mathrm{~K}$ showed the signals of two conformers, in a 1.0 to 5.0 molar ratio.

It is well established in the ${ }^{19} \mathrm{~F}$ NMR spectroscopy that signals due to $o$-F atoms of the $\mathrm{C}_{6} \mathrm{~F}_{5}$ groups bonded to a $\mathrm{PPh}_{2}$ fragment are more shielded than the $o-\mathrm{F}$ atoms of the $\mathrm{C}_{6} \mathrm{~F}_{5}$ groups bonded to a Pt centre, while $m$ - and $p-\mathrm{F}$ atoms of $\mathrm{PPh}_{2} \mathrm{C}_{6} \mathrm{~F}_{5}$ groups are deshielded with respect to the corresponding $\mathrm{Pt}-\mathrm{C}_{6} \mathrm{~F}_{5}$ ones. ${ }^{11,12,14,50-53}$ This means that the fluorine signals due to the $\mathrm{PPh}_{2} \mathrm{C}_{6} \mathrm{~F}_{5}$ group are not overlapped with the fluorine signals of the Pt- $\mathrm{C}_{6} \mathrm{~F}_{5}$ groups and that the presence of the $\mathrm{PPh}_{2} \mathrm{R}_{\mathrm{F}}$ group in $\mathbf{6}$ and $\mathbf{7}$ (at low T) can be unequivocally inferred by ${ }^{19} \mathrm{~F}$ NMR analysis.

The ${ }^{31} \mathrm{P}\left\{{ }^{1} \mathrm{H}\right\}$ NMR spectra of $\mathbf{6}$ and $\mathbf{7}$ in deuteroacetone solution show two singlets flanked by ${ }^{195} \mathrm{Pt}$ satellites. The ${ }^{31} \mathrm{P}$ chemical shifts of the singly phosphanido bridged ligands fall at $\delta-20.7$ and $\delta-18.5$, respectively, in the same region of the phosphanido bridged ligands of 2-5, as expected. ${ }^{39-41}$ The signals due to the $\mathrm{P}^{2}$ atoms of the $\mathrm{PPh}_{2} \mathrm{C}_{6} \mathrm{~F}_{5}$ groups appear at lower fields, at $\delta 10.4$ and $\delta 10.8$, respectively.

VT ${ }^{31} \mathrm{P}\left\{{ }^{1} \mathrm{H}\right\}$ NMR experiments on a deuteroacetone solution of $\mathbf{7}$ (Figure 10) showed a progressive broadening of the ${ }^{31} \mathrm{P}$ NMR signals (more marked in the case of the $\mathrm{P}^{2}$ nucleus) which coalesce at around $233 \mathrm{~K}$. As the temperature decreased further, decoalescence occurred and at $198 \mathrm{~K}$ the signals of two conformers (labelled as $A$ and $B$ in Figure 10) were observed. One conformer, $A$, constituting ca. $83 \%$ in mol, was characterised by signals at $\delta 10.2\left(\mathrm{P}^{2}\right)$ and $\delta-18.5\left(\mathrm{P}^{1}\right)$ while the other one, $B$, ca. $17 \%$ in mol, displaying signals at $\delta 14.0\left(\mathrm{P}^{2}\right)$ and $\delta-19.2\left(\mathrm{P}^{1}\right)$. 

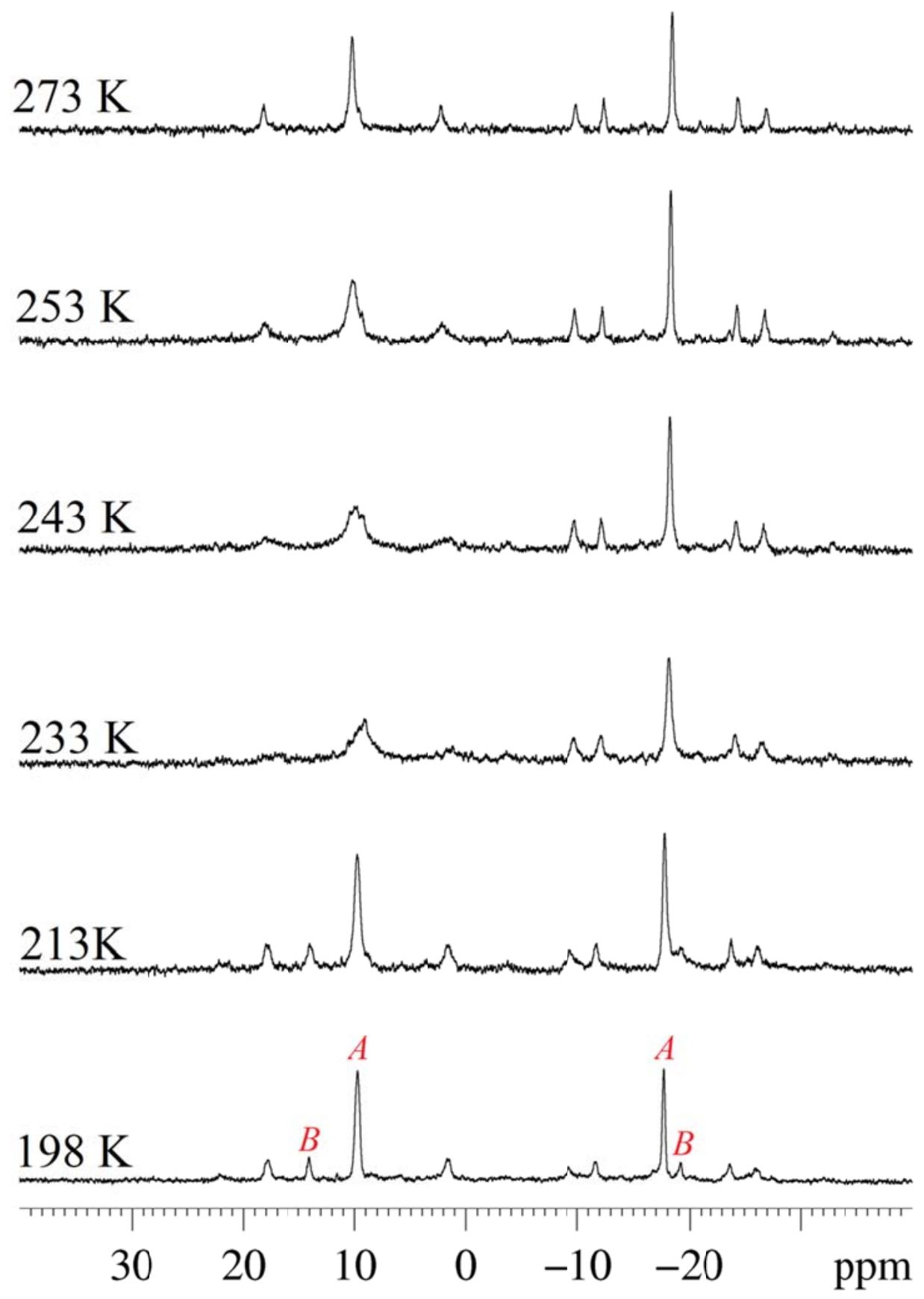

Figure 10. VT ${ }^{31} \mathrm{P}\left\{{ }^{1} \mathrm{H}\right\}$ NMR spectrum of 7 (acetone- $d_{6}$ ). 
The main molecular motions that can explain the dynamic behaviour observed in ${ }^{1} \mathrm{H}$, ${ }^{19} \mathrm{~F}$ and ${ }^{31} \mathrm{P}$ NMR experiments are the hindered rotation of the pentafluorophenyl rings about the $\mathrm{C}-\mathrm{P}$ or $\mathrm{C}-\mathrm{Pt}$ bonds, the rotation of the $\mathrm{P}\left(\mathrm{C}_{6} \mathrm{~F}_{5}\right) \mathrm{Ph}_{2}$ ligand about the $\mathrm{P}-\mathrm{Pt}$ bond and the rotations of the $\mathrm{Pt}^{1 / 2}$ coordination planes about the $\mathrm{Pt}^{1 / 2}-\mathrm{P}^{1}$ bonds. A plausible explanation of the observed dynamic NMR is that at room temperature the rotation of the $\mathrm{Pt}^{1 / 2}$ coordination planes about the $\mathrm{Pt}^{1 / 2}-\mathrm{P}^{1}$ bonds and the rotation of the $\mathrm{P}\left(\mathrm{C}_{6} \mathrm{~F}_{5}\right) \mathrm{Ph}_{2}$ ligand about the $\mathrm{P}-\mathrm{Pt}$ bond are fast, while the rotation of the pentafluorophenyl rings about the $\mathrm{C}-\mathrm{P}$ or $\mathrm{C}-\mathrm{Pt}$ bonds are slow, determining the broadness of the ${ }^{1} \mathrm{H}$ and ${ }^{19} \mathrm{~F}$ signals. At very low $\mathrm{T}$, rotation of pentafluorophenyl rings, as well as that of the $\mathrm{Pt}^{2}$ coordination plane about the $\mathrm{Pt}^{2}-\mathrm{P}^{1}$ bond are blocked, and the only possible molecular motions are the slow rotation of the $\mathrm{Pt}^{1}$ coordination plane about the $\mathrm{Pt}^{1}-\mathrm{P}^{1}$ bond and the rotation of the $\mathrm{P}\left(\mathrm{C}_{6} \mathrm{~F}_{5}\right) \mathrm{Ph}_{2}$ ligand about the $\mathrm{P}^{2}-\mathrm{Pt}^{1}$ bond. That the rotation of the $\mathrm{Pt}^{2}$ coordination plane about the $\mathrm{Pt}^{2}-\mathrm{P}^{1}$ bond is blocked at $198 \mathrm{~K}$ is indicated by intense NOE contact ${ }^{62}$ detected in the ${ }^{1} \mathrm{H}$ NOESY spectrum of 7 at $198 \mathrm{~K}$ between the $\mathrm{C}^{49}-\mathrm{N}^{1}$ $\mathrm{CH}$ proton at $\delta 5.27$ and the ortho protons of one of the phenyl ring bound to the bridging phosphanide ( $\delta 9.36$ and $\delta 8.2$, Figure 11). A clue of the hindered rotation of the $\mathrm{P}\left(\mathrm{C}_{6} \mathrm{~F}_{5}\right) \mathrm{Ph}_{2}$ ligand about the $\mathrm{P}^{2}-\mathrm{Pt}^{1}$ bond at $198 \mathrm{~K}$ is the fact that $\mathrm{P}^{2} \mathrm{Ph}_{2}$ and pyrimidine protons are detected as clear signals in the ${ }^{1} \mathrm{H}$ NMR spectrum at $198 \mathrm{~K}$ (see above).

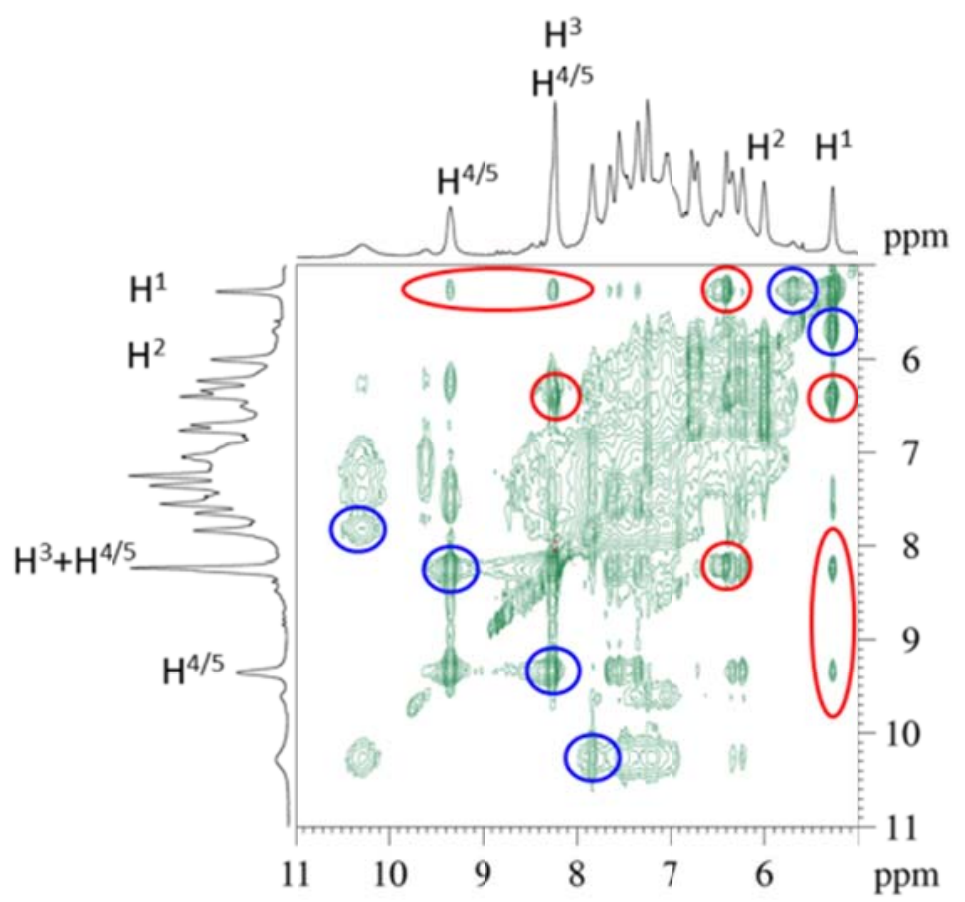


Figure 11. Portion of ${ }^{1} \mathrm{H}$ NOESY spectrum of 7 (acetone- $d_{6}, 198 \mathrm{~K}$ ). Exchange cross peaks are circled in blue, while NOE contacts are circled in red.

These data suggest that the molecular motion responsible for the presence of two conformers at $198 \mathrm{~K}$ is the slow rotation of the $\mathrm{Pt}^{1}$ coordination plane about the $\mathrm{Pt}^{1}-\mathrm{P}^{1}$ bond. Thus, we propose that the most abundant conformer detectable in solution (conformer A) is the one preserving the structure observed in the solid state, being conformer $\mathrm{B}$ the one obtained by $180^{\circ} \mathrm{C}$ rotation of the $\mathrm{Pt}^{1}$ coordination plane about the $\mathrm{Pt}^{1}-\mathrm{P}^{2}$ bond (Scheme 5).

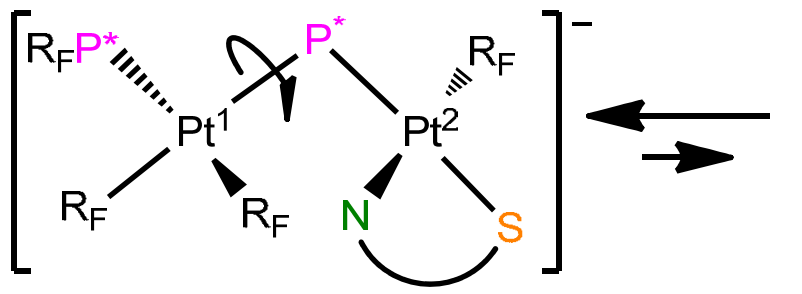

conformer A

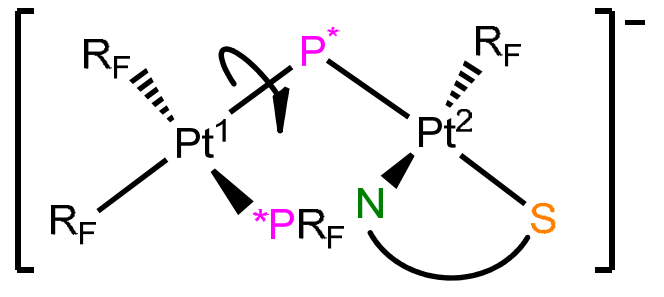

conformer B

$$
\begin{aligned}
& \mathrm{N}^{\wedge} \mathrm{S}^{-}=\left\langle\mathrm{I}^{\mathrm{N}} \cdot \mathrm{S}^{-}\right. \\
& \mathrm{P}^{*}=\mathrm{PPh}_{2} \\
& \mathrm{R}_{\mathrm{F}}=\mathrm{C}_{6} \mathrm{~F}_{5}
\end{aligned}
$$

Scheme 5. Proposed molecular motion of the anion of complex 7 resulting, at low $\mathrm{T}$, in the freezing of conformers A (major) and B (minor).

The ${ }^{195} \mathrm{Pt}$ NMR signals of 6 at $298 \mathrm{~K}$ were found at $\delta-4427\left(\mathrm{Pt}^{1}\right)$ and $-4302\left(\mathrm{Pt}^{2}\right)$, while those of complex 7 were detected (at $203 \mathrm{~K}$ ) at $\delta-4449\left(\mathrm{Pt}^{1}\right)$ and $-4431\left(\mathrm{Pt}^{2}\right)$. No differentiation between the signals of the two conformers could be achieved in the ${ }^{19} \mathrm{~F}$ ${ }^{195} \mathrm{Pt}$ HMQC spectrum of $\mathbf{7}$ at $203 \mathrm{~K}$, due to low resolution.

The IR spectra of $\mathbf{6}$ and $\mathbf{7}$ in the solid state provide additional information that unambiguously indicates the presence of the $\mathrm{PPh}_{2}\left(\mathrm{C}_{6} \mathrm{~F}_{5}\right)$ group. Besides the strong signals around 1500 and $950 \mathrm{~cm}^{-1}$ always observed in all pentafluorophenyl derivatives with $\mathrm{M}-\mathrm{C}_{6} \mathrm{~F}_{5}$ bond, two absorptions of low intensity at higher frequencies, ca. 1580 and $980 \mathrm{~cm}^{-1}$, assignable to the $\mathrm{PPh}_{2}\left(\mathrm{C}_{6} \mathrm{~F}_{5}\right)$ ligand ${ }^{11,14,50,53}$ are present in the IR spectra of 6 and 7. 


\section{DISCUSSION}

The oxidative addition and the reductive elimination are fundamental steps in the study of transition-metal chemistry of platinum and palladium in high oxidation states. ${ }^{1-8}$ Direct reductive coupling processes from 18-electron octahedral M(IV) derivatives are rare, and the dissociation of one of the ligands affording 16-electron unsaturated derivatives with subsequent reductive coupling forming the $\mathrm{M}$ (II) complex is the usually proposed path. ${ }^{21,22,63-67}$ It is to note that complexes $\mathbf{3}$ and $\mathbf{6}$, as well as $\mathbf{4}$ and $\mathbf{7}$, constitute two examples of constitutional isomers. The synthesis of $\mathbf{3}$ and $\mathbf{4}$ (complexes with $\mathrm{P}-\mathrm{S}$ bond) or $\mathbf{6}$ and $\mathbf{7}$ (complexes with $\mathrm{P}-\mathrm{C}$ bond) originates from the same starting materials, same reaction conditions but with different solvent: acetone or dichloromethane, respectively. Scheme 6 shows a process that could explain the formation of our isomers.

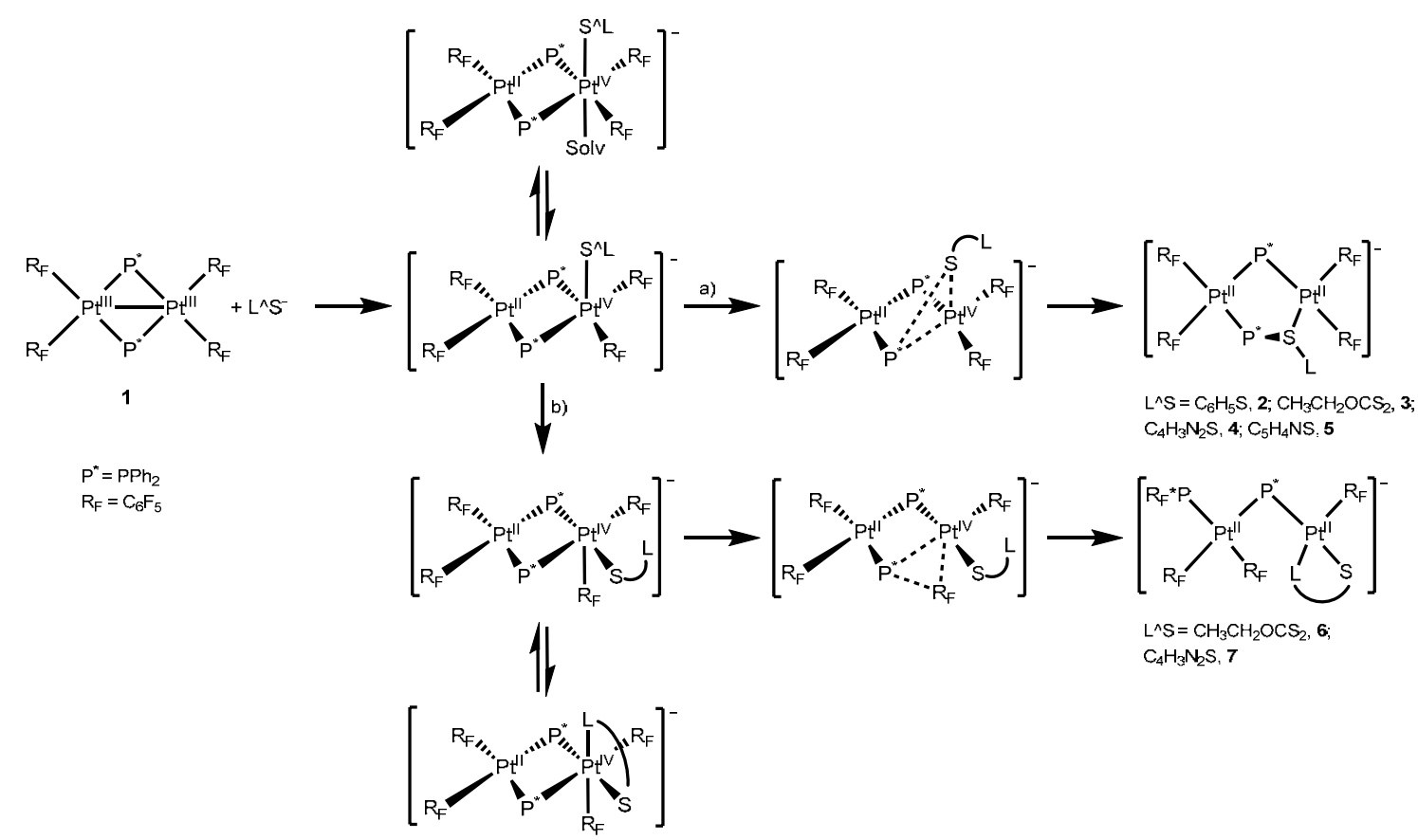

Scheme 6. Plausible processes explaining the syntheses of 2-5 in acetone and 6-7 in dichloromethane.

The nucleophilic sulfur centre of the mono- $\left(\mathrm{PhS}^{-}\right)$or bidentate $\left(\mathrm{EtOCS}_{2}{ }^{-}\right.$, pymS ${ }^{-}$and pyS $^{-}$) fragments coordinates easily to one platinum(III) centre of the symmetrical complex 1 affording a new anionic unsymmetrical $\mathrm{Pt}(\mathrm{II}), \mathrm{Pt}(\mathrm{IV})$ intermediate that contains a 16-electron unsaturated Pt(IV) centre. It is noteworthy that this unsaturated metal centre is formed by addition of the S-based anion to the starting platinum(III) 
centre, not by a dissociation of a ligand from an 18-electron octahedral saturated platinum(IV). In a coordinating solvent such as acetone (path $a$ ), a solvent molecule could favour the stabilization of the five-coordinated Pt(IV) intermediate which, by reductive elimination of the $\mathrm{PPh}_{2}$ and LS fragments, originates new neutral $\mathrm{Ph}_{2} \mathrm{P}-\mathrm{SL}$ ligands and a platinum(II) centre. One lone pair of the sulfur atom coordinates this platinum(II) centre (complexes 2-5).

In $\mathrm{CH}_{2} \mathrm{Cl}_{2}$ solution and in presence of a bidentate ligand (path $b$ ), the intermediate containing a $\mathrm{Pt}(\mathrm{II})$ and a five-coordinated $\mathrm{Pt}(\mathrm{IV})$ could be stabilized by a chelate coordination of the bidentate ligand affording an intermediate containing an octahedral platinum(IV) species. Partial dissociation of the Pt-L $(\mathrm{L}=\mathrm{S}$ or $\mathrm{N})$ bond trans to the $\mathrm{C}_{6} \mathrm{~F}_{5}$ group would be an easy process in these four member rings and thus the reductive elimination of the of $\mathrm{PPh}_{2}$ and $\mathrm{C}_{6} \mathrm{~F}_{5}$ fragments on the unsaturated $\mathrm{Pt}(\mathrm{IV})$ can form the neutral $\mathrm{Ph}_{2} \mathrm{P}-\mathrm{C}_{6} \mathrm{~F}_{5}$ ligand along with the new $\mathrm{Pt}(\mathrm{II})$ centre which satisfies its electronic requirements by the coordination of the bidentate groups as chelating ligands (complexes 6 and 7).

With the aim of gaining insights into the role of the solvent in the reaction of $\mathbf{1}$ with Sbased anions, we carried out the reaction between $\mathrm{KEtOCS}_{2}$ (methanol solution) and $\mathbf{1}$ in toluene, a poorly coordinating solvent and in acetonitrile, a good coordinating solvent. The reaction carried out in toluene afforded smoothly complex $\mathbf{6}$, while the reaction conducted in acetonitrile yielded a mixture of $\mathbf{3}$ and $\mathbf{6}$. The results obtained in toluene parallels that obtained in dichloromethane, thus reinforcing our hypothesis on the role of the solvent in this reaction. However, the formation of $\mathbf{6}$ together with $\mathbf{3}$ (the expected product) seems to put into question the mechanism proposed in Scheme 4.

In order to clarify this unexpected result, a sample of the yellow complex $\mathbf{1}$ was dissolved in acetonitrile (or in $\mathrm{CH}_{2} \mathrm{Cl}_{2}$ plus few drops of acetonitrile) at room temperature (Scheme 7). The yellow solutions progressively cleared and became colourless in ca. half an hour. Work up of the colourless solution afforded in high yield a white solid which was characterized as the neutral complex $\left[\left(\mathrm{PPh}_{2} \mathrm{R}_{\mathrm{F}}\right)\left(\mathrm{CH}_{3} \mathrm{CN}\right)\left(\mathrm{R}_{\mathrm{F}}\right) \mathrm{Pt}^{\mathrm{II}}\left(\mu-\mathrm{PPh}_{2}\right) \mathrm{Pt}^{\mathrm{II}}\left(\mathrm{R}_{\mathrm{F}}\right)_{2}\left(\mathrm{CH}_{3} \mathrm{CN}\right)\right](\mathbf{8}$, Scheme 7). 


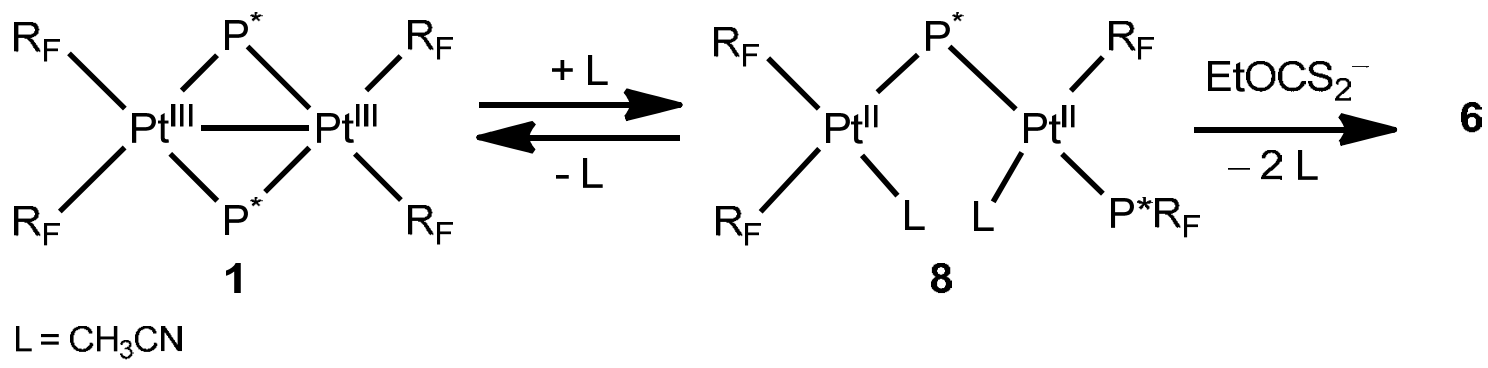

Scheme 7. Behaviour of $\mathbf{1}$ in acetonitrile.

Formation of complex 8 can thus explain the unexpected formation of $\mathbf{6}$ in the reaction of 1 with $\mathrm{EtOCS}_{2}^{-}$in MeCN. In fact, the addition of $\mathrm{KEtOCS}_{2}$ to a colourless solution of $\mathbf{8}$ in acetonitrile in 1:1 molar ratio gave, as the only product, complex $\mathbf{6}$.

The characterization of complex 8 was carried out by elemental analysis, HRMS, XRD, IR and multinuclear NMR spectroscopy.

A drawing of the XRD structure of complex 8, together with the atom-labelling scheme, is shown in Figure 12. Selected bond distances and angles are listed in Table S4. Crystal data and refinement parameters are given in Table S1.

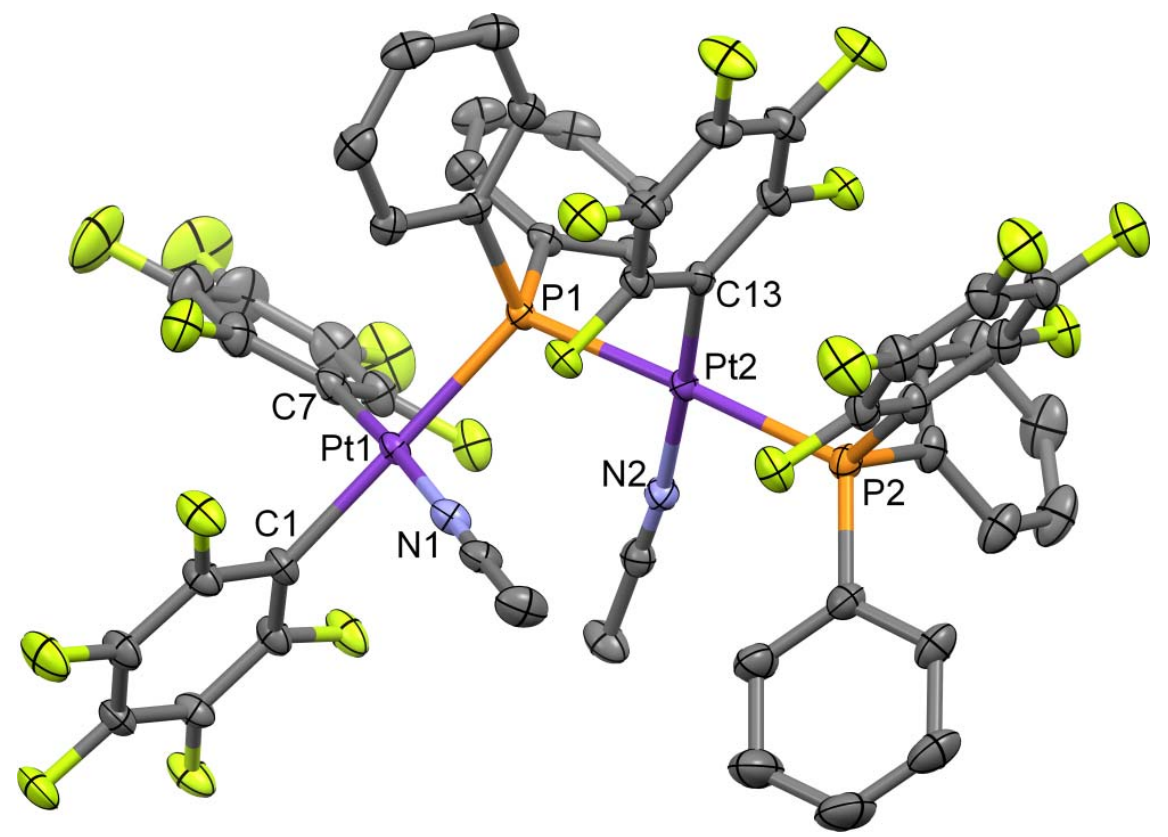

Figure 12. Crystal structure of complex $\left[\left(\mathrm{PPh}_{2} \mathrm{R}_{\mathrm{F}}\right)\left(\mathrm{R}_{\mathrm{F}}\right)\left(\mathrm{CH}_{3} \mathrm{CN}\right) \mathrm{Pt}^{\mathrm{II}}(\mu-\right.$ $\left.\left.\mathrm{PPh}_{2}\right) \mathrm{Pt}^{\mathrm{II}}\left(\mathrm{CH}_{3} \mathrm{CN}\right)\left(\mathrm{R}_{\mathrm{F}}\right)_{2}\right] \cdot 1.5 \mathrm{CH}_{3} \mathrm{CN}\left(\mathbf{8} \cdot 1.5 \mathrm{CH}_{3} \mathrm{CN}\right)$. Ellipsoids are drawn at their $50 \%$ probability level. Hydrogen atoms have been omitted for clarity. 
The ${ }^{31} \mathrm{P}\left\{{ }^{1} \mathrm{H}\right\}$ NMR spectrum of $\mathbf{8}$ consists of the superimposition of four isotopologues corresponding to: an $\mathrm{AB}$ (45\%), two $\mathrm{ABX}$ (22\% each), and an $\mathrm{ABXY}$ (11\%) spin systems, where A and B are ${ }^{31} \mathrm{P}$, while $\mathrm{X}$ and $\mathrm{Y}$ are ${ }^{195} \mathrm{Pt}$. The whole spectrum was calculated (Figure 13) and the spectroscopic features reported in the experimental part were obtained. The chemical shift of the bridging $\mathrm{PPh}_{2}$ is at $\delta 1.8$ while that of the terminal $\mathrm{PPh}_{2}\left(\mathrm{C}_{6} \mathrm{~F}_{5}\right)$ is at $\delta$ 4.2. The ${ }^{1} \mathrm{H}$ NMR spectrum of 8 in acetone- $d_{6}$ at $298 \mathrm{~K}$ showed, beside well resolved signals attributable to aromatic protons, two singlets at $\delta$ 2.33 and $\delta 2.16$ ascribable to coordinated MeCN molecules. The ${ }^{19} \mathrm{~F}$ NMR signals of the terminal $\mathrm{PPh}_{2}\left(\mathrm{C}_{6} \mathrm{~F}_{5}\right)$ ligand ${ }^{11,50}$ were found at $\delta-125.3$ (ortho-F), $\delta-149.7$ (para-F), $\delta-$ 162.0 (meta-F) while the ${ }^{195} \mathrm{Pt}$ NMR signals fell at $\delta-4104\left(\mathrm{Pt}^{1}\right)$ and $-4414\left(\mathrm{Pt}^{2}\right)$.

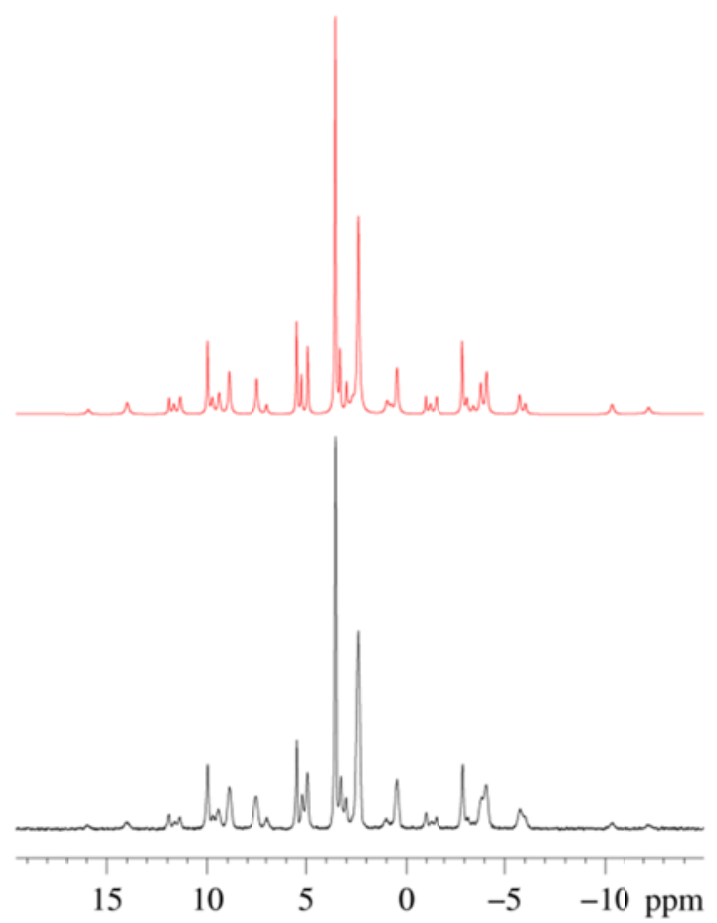

Figure 13. Experimental (bottom) and calculated (top) ${ }^{31} \mathrm{P}\left\{{ }^{1} \mathrm{H}\right\}$ NMR spectra of 8 in acetone- $d_{6}$ at $298 \mathrm{~K}$.

The synthesis of $\mathbf{8}$ resembles the reaction between $\mathbf{1}$ and $\mathrm{I}^{-}$which led to the isolation of the anion $\left[\left(\mathrm{PPh}_{2} \mathrm{R}_{\mathrm{F}}\right)\left(\mathrm{R}_{\mathrm{F}}\right) \mathrm{Pt}^{\mathrm{II}}\left(\mu-\mathrm{PPh}_{2}\right)(\mu-\mathrm{I}) \mathrm{Pt}^{\mathrm{II}}\left(\mathrm{R}_{\mathrm{F}}\right)_{2}\right]^{-50}$ with the difference that $\mathrm{CH}_{3} \mathrm{CN}$ do not bridge the Pt atoms in the reaction product. The formation of $\mathbf{8}$ can be explained by initial coordination of the neutral acetonitrile ligand to one of the platinum centres of $\mathbf{1}$, forming a $\mathrm{Pt}(\mathrm{II}), \mathrm{Pt}(\mathrm{IV})$ intermediate which would undergo a reductive coupling between the two formally anionic fragments $\left(\mathrm{PPh}_{2}\right.$ and $\left.\mathrm{C}_{6} \mathrm{~F}_{5}\right)$ coordinated to the unsaturated 
platinum(IV) intermediate forming $\mathrm{PPh}_{2} \mathrm{R}_{\mathrm{F}}{ }^{11,12,14,50-53}$ Coordination of a second molecule of acetonitrile would afford complex 8. It is to note that in all our earlier reported reductive processes affording the $\mathrm{PPh}_{2} \mathrm{R}_{\mathrm{F}}$ ligand, the reactions were facilitated by an anionic fragment as nucleophile. In the present case, the nitrogen atom of the neutral acetonitrile molecule is able to coordinate to the platinum(III) centre and trigger the reaction, indicating a very electrophilic character of the platinum(III) centre in complex 1 .

Complex 8 deserves some attention. Solutions of 8 in $\mathrm{CH}_{2} \mathrm{Cl}_{2}$ and few drops of acetonitrile remain colourless indefinitely but the solutions of 8 in pure $\mathrm{CH}_{2} \mathrm{Cl}_{2}$ or in toluene become yellow. These solutions were layered with $n$-hexane and left to crystallize at room temperature. In the first case $\left(\mathrm{CH}_{2} \mathrm{Cl}_{2}\right.$ plus few drops of acetonitrile) only colourless crystals of $\mathbf{8}$ were obtained. Nevertheless, in the other two solutions $\left(\mathrm{CH}_{2} \mathrm{Cl}_{2}\right.$ or toluene) some yellow-orange crystals were observed along with the colourless crystals. A manual separation of the two types of crystals permitted to identify them (IR spectroscopy) as $\mathbf{1}$ (yellow crystals) and $\mathbf{8}$ (colourless crystals). This indicates that, dissolving $\mathbf{8}$ in poorly coordinating solvents triggers an equilibrium between $\mathbf{1}$ and $\mathbf{8}$ making the oxidative addition/reductive elimination with formation of a $\mathrm{Ph}_{2} \mathrm{P}-\mathrm{C}_{6} \mathrm{~F}_{5}$ bond a reversible process in smooth conditions (Scheme 7). Consistently with this, slow evaporation of acetone solutions of $\mathbf{8}$ afforded pure $\mathbf{1}$ as a yellow solid.

It is noteworthy that although some examples of this transformations between bridging phosphanides and tertiary phosphanes or diphosphanes have been reported, ${ }^{15,50,68-71}$ the reversibility observed between the yellow Pt(III) complex 1 and the colourless Pt(II) complex $\mathbf{8}$ is actually a quite unusual process.

\section{CONCLUDING REMARKS}

The oxidative addition/reductive elimination process makes the platinum centres to shift between II and IV oxidation states, or III for dinuclear complexes such as in the diplatinum(III) derivative $\mathbf{1}$. The reductive elimination chemistry of organoplatinum(IV) complexes usually forms C-X bonds and many studies have been focused on finding conditions for selective formation of some specific bonds. In our research on the perfluorophenyl- and diphenylphosphanido derivative of diplatinum(III), $\mathbf{1}$, the complex shows $\mathrm{Pt}(\mathrm{III})-\mathrm{C}$ and $\mathrm{Pt}(\mathrm{III})-\mathrm{P}$ bonds. In the reductive coupling processes from this 
oxidised specie, the formation of the $\mathrm{P}-\mathrm{X}(\mathrm{X}=\mathrm{S}, \mathrm{C})$ bond is always observed instead of the $\mathrm{C}-\mathrm{X}(\mathrm{X}=\mathrm{S}, \mathrm{C})$ one.

The synthesis of the thiophosphane complex $\mathbf{2}$ in acetone as well as in dichloromethane demonstrates that when the monodentate ligand is added to $\mathbf{1}$, the reductive coupling of the bridging diphenylphosphanido group with the added ligand is observed. The formation of a $\mathrm{P}-\mathrm{S}$ bond $\left(\mathrm{PPh}_{2} \mathrm{SR}\right)$ is preferred to the formation of a $\mathrm{P}-\mathrm{C}$ one $\left(\mathrm{PPh}_{2} \mathrm{C}_{6} \mathrm{~F}_{5}\right)$. The addition of bidentate anionic groups to $\mathbf{1}$ proves that both reductive processes, formation of $\mathrm{P}-\mathrm{S}$ or $\mathrm{P}-\mathrm{C}$ bonds, are possible. The reaction in acetone proceeds by reductive coupling of bridging diphenylphosphanido and thiolate groups and it can be seen as a metal assisted way to synthesise new specific thiophosphane ligands through the adequate choice of the $\mathrm{RS}^{-}$reagent.

The addition of $\mathrm{RS}^{-}$anions to complex 1 did not afford stable platinum(IV) complexes since a reductive coupling takes place probably through an unsaturated five-coordinated 16-electron Pt(IV). It is to note that the unsaturated intermediates have been usually formed by dissociation of a ligand from the octahedral Pt(IV) system but in our work these intermediates are proposed to be formed by addition of a ligand to the squareplanar Pt(III) system.

Although phosphanido groups are classically used for maintaining the molecular architecture of polynuclear transition metal complexes, mainly due to their great flexibility and to the strong $\mathrm{P}-\mathrm{M}$ bonds, it is now well established that bridging phosphanido groups can act as reaction centres. ${ }^{51,53,68,71,72}$ This work demonstrates that the oxidation of the metal centres in platinum(II) complexes is a way to efficiently trigger an often a priori unpredictable reactivity of bridging phosphanido ligands.

\section{EXPERIMENTAL SECTION}

General Procedures and Materials. C, H, and N analyses were performed with a Perkin-Elmer 2400 CHNS analyser. IR spectra were recorded on a Perkin-Elmer Spectrum 100 FT-IR spectrometer (ATR in the range 250-4000 $\mathrm{cm}^{-1}$ ). NMR spectra in solution were recorded on a Bruker AV-400 spectrometer with $\mathrm{SiMe}_{4}, \mathrm{CFCl}_{3}, \mathrm{H}_{2} \mathrm{PtCl}_{6}$ and $85 \% \mathrm{H}_{3} \mathrm{PO}_{4}$ as external references for ${ }^{1} \mathrm{H},{ }^{19} \mathrm{~F},{ }^{195} \mathrm{Pt}$ and ${ }^{31} \mathrm{P}$, respectively. The signal attributions and coupling constant assessment was made on the basis of a multinuclear NMR analysis including ${ }^{1} \mathrm{H}_{-}{ }^{31} \mathrm{P}$ HMQC, ${ }^{19} \mathrm{~F}-{ }^{195} \mathrm{Pt}$ HMQC, COSY and NOESY 
experiments. High Resolution Mass Spectrometry (HR-MS) analyses were performed using a time-of-flight mass spectrometer equipped with an electrospray ion source (Bruker micrOTOF II). The sample solutions were introduced by continuous infusion with the aid of a syringe pump at a flow-rate of $180 \mu \mathrm{L} / \mathrm{h}$. The instrument was operated at end plate offset $-500 \mathrm{~V}$ and capillary $-4500 \mathrm{~V}$. Nebulizer pressure was 0.3 bar $\left(\mathrm{N}_{2}\right)$ and the drying gas $\left(\mathrm{N}_{2}\right)$ flow $4.0 \mathrm{~L} / \mathrm{min}$. Capillary exit was $170 \mathrm{~V}$. Drying gas temperature was set at $180^{\circ} \mathrm{C}$. The software used for the simulations is Bruker Daltonics Data Analysis (version 4.0). Literature method was used to prepare the starting material $\left.\left[\left(\mathrm{R}_{\mathrm{F}}\right)_{2} \mathrm{Pt}^{\mathrm{III}}\left(\mu-\mathrm{PPh}_{2}\right)_{2} \mathrm{Pt}^{\mathrm{III}}\left(\mathrm{R}_{\mathrm{F}}\right)_{2}\right)\right](P t-P t){ }^{9}$

\section{$\left[\mathrm{N}^{\mathrm{n}} \mathrm{Bu}_{4}\right]\left[\left(\mathrm{C}_{6} \mathrm{~F}_{5}\right)_{2} \mathrm{Pt}\left(\boldsymbol{\mu}-\mathrm{PPh}_{2}\right)\left\{\kappa^{2} P, S-\mu-\mathrm{P}(\mathrm{SPh}) \mathrm{Ph}_{2}\right\} \operatorname{Pt}\left(\mathrm{C}_{6} \mathrm{~F}_{5}\right)_{2}\right](2)$}

To a yellow solution of $1(0.133 \mathrm{~g}, 0.093 \mathrm{mmol})$ in $\mathrm{CH}_{2} \mathrm{Cl}_{2}(25 \mathrm{~mL}) 0.094 \mathrm{mmol}$ of $\mathrm{N}^{\mathrm{n}} \mathrm{Bu}_{4} \mathrm{SPh}$ methanol solution (the solution was prepared through the addition of $\mathrm{MeOH}$ to equimolar amounts of $\mathrm{PhSH}$ and of a commercial $\mathrm{N}^{\mathrm{n}} \mathrm{Bu}_{4} \mathrm{OH} 1.0 \mathrm{M}$ methanol solution) were added. The solution was stirred at room temperature for $20 \mathrm{~h}$ and the resulting colourless solution was evaporated to ca. $1 \mathrm{~mL}$. ${ }^{\mathrm{i}} \mathrm{PrOH}(5 \mathrm{~mL})$ was added and 2 crystallised as a white solid which was filtered, washed with ${ }^{\mathrm{i}} \mathrm{PrOH}(2 \times 0.5 \mathrm{~mL})$ and dried in vacuum. Yield: $0.074 \mathrm{~g}, 45 \%$ Anal. Found (calcd for $\mathrm{C}_{70} \mathrm{~F}_{20} \mathrm{H}_{61} \mathrm{NP}_{2} \mathrm{Pt}_{2} \mathrm{~S}$ ): $\mathrm{C}$, 47.01 (47.22); H, 3.45 (3.45); N, 0.61 (0.79); S, 1.64 (1.80). HRMS(-), exact mass for the anion $[\mathrm{M}]^{-}: 1537.0126$ Da; measured: $\mathrm{m} / \mathrm{z}: 1537.0233(\mathrm{M})^{-}$.

IR ( $\mathrm{cm}^{-1}$ ): 952 and 799, 789, 777 (X-sensitive), $\mathrm{C}_{6} \mathrm{~F}_{5} \cdot{ }^{73}{ }^{1} \mathrm{H}$ NMR (acetone- $d_{6}, 298$ $\mathrm{K}, 400 \mathrm{MHz}$ ), $\delta: 7.79\left(\mathrm{dd},{ }^{3} J_{\mathrm{H}, \mathrm{P}}=9.8 \mathrm{~Hz},{ }^{3} J_{\mathrm{H}, \mathrm{H}}=8.2 \mathrm{~Hz}, 4\right.$ ortho- $\mathrm{H}$ of $\mathrm{Ph}_{2} \mathrm{P}^{1}$ ), 7.72 (dd, ${ }^{3} J_{\mathrm{H}, \mathrm{P}}=10.7 \mathrm{~Hz},{ }^{3} J_{\mathrm{H}, \mathrm{H}}=8.2 \mathrm{~Hz}, 4$ ortho- $\mathrm{H}$ of $\left.\mathrm{Ph}_{2} \mathrm{P}^{2} \mathrm{~S}\right), 7.58\left(\mathrm{~m},{ }^{3} J_{\mathrm{H}, \mathrm{H}}=7.5 \mathrm{~Hz}, 2\right.$ para $-\mathrm{H}$ of $\mathrm{Ph}_{2} \mathrm{P}^{2} \mathrm{~S}$ ), 7.41 (pseudo td, ${ }^{3} J_{\mathrm{H}, \mathrm{H}} \approx 7.8 \mathrm{~Hz},{ }^{4} J_{\mathrm{H}, \mathrm{P}}=2.5 \mathrm{~Hz}, 4$ meta-H of $\mathrm{Ph}_{2} \mathrm{P}^{2} \mathrm{~S}$ ), 7.20 (m, overlapped 2 para-H of $\mathrm{Ph}_{2} \mathrm{P}^{1}+1$ para-H of $\mathrm{PhS}$ ), 7.14 (pseudo td, ${ }^{3} J_{\mathrm{H}, \mathrm{H}} \approx 7.8 \mathrm{~Hz}$, ${ }^{4} J_{\mathrm{H}, \mathrm{P}}=1.5 \mathrm{~Hz}, 4$ meta-H of $\left.\mathrm{Ph}_{2} \mathrm{P}^{1}\right) 6.87\left(\mathrm{~m},{ }^{3} J_{\mathrm{H}, \mathrm{H}}=7.6 \mathrm{~Hz}, 2\right.$ meta-H of $\left.\mathrm{PhS}\right), 6.72(\mathrm{~d}$, ${ }^{3} J_{\mathrm{H}, \mathrm{H}}=7.6 \mathrm{~Hz}$, , 2 ortho-H of $\left.\mathrm{PhS}\right), 3.50\left(\mathrm{~m}, 8 \mathrm{H}, \mathrm{NBu}_{4}{ }^{+}\right), 1.88\left(\mathrm{~m}, 8 \mathrm{H}, \mathrm{NBu}_{4}{ }^{+}\right), 1.49$ (pseudo sextet, ${ }^{3} J_{\mathrm{H}, \mathrm{H}}=8 \mathrm{~Hz}, 8 \mathrm{H}, \mathrm{NBu}_{4}{ }^{+}$), $1.03\left(\mathrm{t},{ }^{3} J_{\mathrm{H}, \mathrm{H}}=7,2 \mathrm{~Hz}, 12 \mathrm{H}, \mathrm{NBu}_{4}{ }^{+}\right) \cdot{ }^{19} \mathrm{~F}$ NMR (acetone- $d_{6}, 298 \mathrm{~K}, 376.5 \mathrm{MHz}$ ), $\delta:-115.2\left(\mathrm{~m},{ }^{3} J_{\mathrm{Pt}, \mathrm{F}}=345 \mathrm{~Hz}, 2\right.$ ortho-F), -116.1 $\left({ }^{3} J_{\mathrm{Pt}, \mathrm{F}}=262 \mathrm{~Hz},{ }^{3} J_{\mathrm{Pt}, \mathrm{F}}=280 \mathrm{~Hz}\right.$, 4 ortho-F of a $\mathrm{C}_{6} \mathrm{~F}_{5}$ bonded to $\mathrm{Pt}^{1}$ and of a $\mathrm{C}_{6} \mathrm{~F}_{5}$ bonded to $\left.\mathrm{Pt}^{2}\right),-116.5\left(\mathrm{~m},{ }^{3} J_{\mathrm{Pt}, \mathrm{F}}=466 \mathrm{~Hz} 2\right.$ ortho-F of the $\mathrm{C}_{6} \mathrm{~F}_{5}$ trans to $\left.\mathrm{S}\right),-165.1$ (t, ${ }^{3} J_{\mathrm{F}, \mathrm{F}}=$ 19.7 Hz, 1 para-F), -165.5 (t, ${ }^{3} J_{\mathrm{F}, \mathrm{F}}=19.9 \mathrm{~Hz}, 1$ para-F), -165.8 (pseudo td, ${ }^{3} J_{\mathrm{F}, \mathrm{F}}=21.0$ 
$\mathrm{Hz},{ }^{5} J_{\mathrm{F}, \mathrm{P}}=7.7 \mathrm{~Hz}, 2$ meta-F), $-166.2\left(\mathrm{ddd},{ }^{3} J_{\mathrm{F}, \mathrm{F}}=21.7 \mathrm{~Hz},{ }^{3} J_{\mathrm{F}, \mathrm{F}}=19.9 \mathrm{~Hz},{ }^{5} J_{\mathrm{F}, \mathrm{P}}=7.9\right.$ $\mathrm{Hz}, 2$ meta-F), -166.8 (m, overlapped 2 meta-F +1 para-F), $-167.5\left(\mathrm{~m},{ }^{3} J_{\mathrm{F}, \mathrm{F}}=19.6 \mathrm{~Hz}\right.$, ${ }^{3} J_{\mathrm{F}, \mathrm{Pt}}=110 \mathrm{~Hz}, 2$ meta-F of the $\mathrm{C}_{6} \mathrm{~F}_{5}$ trans to $\left.\mathrm{S}\right),-167.7$ (t, ${ }^{3} J_{\mathrm{F}, \mathrm{F}}=19.6 \mathrm{~Hz}, 1$ para-F of the $\mathrm{C}_{6} \mathrm{~F}_{5}$ trans to $\left.\mathrm{S}\right) .{ }^{31} \mathrm{P}\left\{{ }^{1} \mathrm{H}\right\} \mathrm{NMR}$ (acetone- $\left.d_{6}, 298 \mathrm{~K}, 162.0 \mathrm{MHz}\right), \delta: 106.5\left({ }^{1} J_{\mathrm{P} 2, \mathrm{Pt} 1}=\right.$ $\left.2673 \mathrm{~Hz}, \mathrm{P}^{2}\right),-13.1\left({ }^{1} J_{\mathrm{P} 1, \mathrm{Pt} 1}=1841 \mathrm{~Hz},{ }^{1} J_{\mathrm{P} 1, \mathrm{Pt} 2}=1893 \mathrm{~Hz}, \mathrm{P}^{1}\right) \mathrm{ppm} .{ }^{195} \mathrm{Pt} \mathrm{NMR}$ (acetone- $\left.d_{6}, 298 \mathrm{~K}, 86 \mathrm{MHz}\right), \delta:-4466\left(\mathrm{Pt}^{1}\right),-4331\left(\mathrm{Pt}^{2}\right)$.

\section{$\left[\mathrm{N}^{\mathrm{n}} \mathrm{Bu}_{4}\right]\left[\left(\mathrm{C}_{6} \mathrm{~F}_{5}\right)_{2} \mathrm{Pt}\left(\mu-\mathrm{PPh}_{2}\right)\left(\mu-\mathrm{Ph}_{2} \mathrm{P}-\mathrm{SCSOEt}\right) \operatorname{Pt}\left(\mathrm{C}_{6} \mathrm{~F}_{5}\right)_{2}\right](3)$}

To a yellow suspension of $1(0.240 \mathrm{~g}, 0.168 \mathrm{mmol})$ in acetone $(15 \mathrm{~mL}) 0.028 \mathrm{~g}$ (0.174 mmol) of KEtOCS 2 in methanol $(3 \mathrm{~mL}$ ) were added. The suspension was stirred at room temperature for $2 \mathrm{~h}$ and the resulting pale yellow solution was evaporated to dryness. The residue was treated with $\mathrm{CH}_{2} \mathrm{Cl}_{2}(5 \mathrm{~mL}), \mathrm{N}^{\mathrm{n}} \mathrm{Bu}_{4} \mathrm{ClO}_{4}(0.058 \mathrm{~g}, 0.169$ mmol) and the resulting mixture was filtered through celite. The solution was evaporated to ca. $2 \mathrm{~mL}$, ${ }^{\mathrm{i}} \mathrm{PrOH}$ (15 mL) was added and complex 3 crystallized as a pale yellow solid which was filtered, washed with ${ }^{\mathrm{i}} \mathrm{PrOH}(3 \times 0.5 \mathrm{~mL})$ and dried in vacuum. Yield: 0.236 g, 77\%. Anal. Found (calcd for $\mathrm{C}_{67} \mathrm{~F}_{20} \mathrm{H}_{61} \mathrm{NOP}_{2} \mathrm{Pt}_{2} \mathrm{~S}_{2}$ ): C, 44.64 (44.90); H, 3.60 (3.43); N 0.65 (0.78); S, 3.85 (3.58). HRMS(-), exact mass for the anion $[\mathrm{M}]^{-}$: 1548.9795 Da; measured: $m / z: 1548.9916(\mathrm{M})^{-}$.

IR ( $\mathrm{cm}^{-1}$ ): 953 and 799, 790, 777 (X-sensitive), $\mathrm{C}_{6} \mathrm{~F}_{5} \cdot{ }^{73}{ }^{1} \mathrm{H}$ NMR (acetone- $d_{6}, 298$ $\mathrm{K}, 400 \mathrm{MHz}$ ), $\delta: 8.27\left(\mathrm{dd},{ }^{3} J_{\mathrm{H}, \mathrm{P}}=11.5 \mathrm{~Hz},{ }^{3} J_{\mathrm{H}, \mathrm{H}}=8.0 \mathrm{~Hz}, 4\right.$ ortho-H of $\left.\mathrm{Ph}_{2} \mathrm{P}^{2} \mathrm{~S}\right), 7.64$ $\left(\mathrm{m},{ }^{3} J_{\mathrm{H}, \mathrm{H}}=7.1 \mathrm{~Hz}, 2\right.$ para-H of $\left.\mathrm{Ph}_{2} \mathrm{P}^{2} \mathrm{~S}\right), 7.57\left(\mathrm{~m},{ }^{3} J_{\mathrm{H}, \mathrm{H}}=7.4 \mathrm{~Hz},{ }^{4} J_{\mathrm{H}, \mathrm{P}}=2.2 \mathrm{~Hz}, 2\right.$ meta$\mathrm{H}$ of $\mathrm{Ph}_{2} \mathrm{P}^{2} \mathrm{~S}$ ), 7.52 (m, 4 ortho-H of $\mathrm{Ph}_{2} \mathrm{P}^{1}$ ), 7.16 (pseudo td, ${ }^{3} J_{\mathrm{H}, \mathrm{H}}=7.3 \mathrm{~Hz},{ }^{4} J_{\mathrm{H}, \mathrm{P}}=1.7$ $\mathrm{Hz}, 2$ para-H of $\mathrm{Ph}_{2} \mathrm{P}^{1}$ ), 7.04 (pseudo td, ${ }^{3} J_{\mathrm{H}, \mathrm{H}}=7.3 \mathrm{~Hz},{ }^{4} J_{\mathrm{H}, \mathrm{P}}=1.5 \mathrm{~Hz}, 4$ meta-H of $\mathrm{Ph}_{2} \mathrm{P}^{1}$ ), 3.95 (q, $2 \mathrm{H}, \mathrm{OCH}_{2} \mathrm{CH}_{3}$ ), $3.51\left(\mathrm{~m}, 8 \mathrm{H}, \mathrm{NBu}_{4}{ }^{+}\right), 1.88\left(\mathrm{~m}, 8 \mathrm{H}, \mathrm{NBu}_{4}{ }^{+}\right), 1.48$ (pseudo sextet, ${ }^{3} J_{\mathrm{H}, \mathrm{H}}=8 \mathrm{~Hz}, 8 \mathrm{H}, \mathrm{NBu}_{4}{ }^{+}$), $1.02\left(\mathrm{t},{ }^{3} J_{\mathrm{H}, \mathrm{H}}=7,2 \mathrm{~Hz}, 12 \mathrm{H}, \mathrm{NBu}_{4}{ }^{+}\right.$), $0.87(\mathrm{t}$, $3 \mathrm{H}, \mathrm{OCH}_{2} \mathrm{CH}_{3}$ ). ${ }^{19} \mathrm{~F}$ NMR (acetone- $d_{6}, 298 \mathrm{~K}, 376.5 \mathrm{MHz}$ ), $\delta$ : from -115.2 to -115.6 (m, overlapped 6 ortho-F of $\mathrm{C}_{6} \mathrm{~F}_{5}$ rings trans to $\mathrm{P}$ atoms),-116.7 (d, ${ }^{3} J_{\mathrm{Pt}, \mathrm{F}}=442 \mathrm{~Hz},{ }^{3} J_{\mathrm{F}, \mathrm{F}}$ $=21.7 \mathrm{~Hz}, 1$ ortho-F of the $\mathrm{C}_{6} \mathrm{~F}_{5}$ trans to $\left.\mathrm{S}\right),-116.8\left(\mathrm{~d},{ }^{3} J_{\mathrm{Pt}, \mathrm{F}}=442 \mathrm{~Hz},{ }^{3} J_{\mathrm{F}, \mathrm{F}}=20.7 \mathrm{~Hz}\right.$, 1 ortho-F of the $\mathrm{C}_{6} \mathrm{~F}_{5}$ trans to S),-164.5 (t, ${ }^{3} J_{\mathrm{F}, \mathrm{F}}=19.8 \mathrm{~Hz}, 1$ para-F), $-164.8\left(\mathrm{t},{ }^{3} J_{\mathrm{F}, \mathrm{F}}=\right.$ $19.8 \mathrm{~Hz}, 1$ para-F), -165.7 (pseudo td, ${ }^{3} J_{\mathrm{F}, \mathrm{F}}=21.4 \mathrm{~Hz},{ }^{5} J_{\mathrm{F}, \mathrm{P}}=7.8 \mathrm{~Hz}, 2$ meta-F), -166.0 (ddd, ${ }^{3} J_{\mathrm{F}, \mathrm{F}}=21.3 \mathrm{~Hz},{ }^{5} J_{\mathrm{F}, \mathrm{P}}=7.8 \mathrm{~Hz}, 2$ meta-F), -166.5 (m, overlapped 2 meta-F +1 para-F), -166.5 (m, overlapped 2 meta-F +1 para-F). ${ }^{31} \mathrm{P}\left\{{ }^{1} \mathrm{H}\right\}$ NMR (acetone- $d_{6}, 298$ 
$\mathrm{K}, 162.0 \mathrm{MHz}), \delta: 104.7\left({ }^{1} J_{\mathrm{P} 2, \mathrm{Pt} 1}=2632 \mathrm{~Hz}, \mathrm{P}^{2}\right),-20.9\left({ }^{1} J_{\mathrm{P} 1, \mathrm{Pt} 1}={ }^{1} J_{\mathrm{P} 1, \mathrm{Pt} 2}=1858 \mathrm{~Hz}, \mathrm{P}^{1}\right)$ ppm. ${ }^{195} \mathrm{Pt}$ NMR (acetone- $\left.d_{6}, 298 \mathrm{~K}, 86 \mathrm{MHz}\right), \delta:-4478\left(\mathrm{Pt}^{1}\right),-4323\left(\mathrm{Pt}^{2}\right)$.

\section{$\left[\mathrm{N}^{\mathrm{n}} \mathrm{Bu}_{4}\right]\left[\left(\mathrm{C}_{6} \mathrm{~F}_{5}\right)_{2} \mathrm{Pt}\left(\boldsymbol{\mu}-\mathrm{PPh}_{2}\right)\left(\mu-\mathrm{Ph}_{2} \mathrm{P}-\mathrm{SC}_{4} \mathrm{H}_{3} \mathrm{~N}_{2}\right) \operatorname{Pt}\left(\mathrm{C}_{6} \mathrm{~F}_{5}\right)_{2}\right](4)$}

To a yellow solution of 1 (0.150 g, $0.105 \mathrm{mmol})$ in acetone (25 mL) $0.105 \mathrm{mmol}$ of $\mathrm{N}^{\mathrm{n}} \mathrm{Bu}_{4} \mathrm{SC}_{6} \mathrm{H}_{3} \mathrm{~N}_{2}$ in methanol solution (the solution was prepared through the addition of $\mathrm{MeOH}$ to equimolar amounts of $\mathrm{C}_{4} \mathrm{H}_{3} \mathrm{~N}_{2} \mathrm{SH}$ and of a commercial $\mathrm{N}^{\mathrm{n}} \mathrm{Bu}_{4} \mathrm{OH} 1.0 \mathrm{M}$ methanol solution) were added. The solution was stirred at room temperature for $20 \mathrm{~h}$ and the resulting colourless solution was evaporated to ca. $1 \mathrm{~mL}$. ${ }^{\mathrm{i}} \mathrm{PrOH}(5 \mathrm{~mL})$ was added and $\mathbf{4}$ crystallised as a white solid which was filtered, washed with ${ }^{\mathrm{i}} \mathrm{PrOH}(2 \times 0.5$ $\mathrm{mL}$ ) and dried in vacuum. Yield: $0.123 \mathrm{~g}$, 65\% Anal. Found (calcd for $\mathrm{C}_{68} \mathrm{~F}_{20} \mathrm{H}_{59} \mathrm{~N}_{3} \mathrm{P}_{2} \mathrm{Pt}_{2} \mathrm{~S}$ ): C, 45.63 (45.82); H, 3.33 (3.34); N, 2.41 (2.36); S, 1.98 (1.80). HRMS(-), exact mass for the anion $[\mathrm{M}]^{-}: 1539.0031 \mathrm{Da}$; measured: $\mathrm{m} / \mathrm{z}: 1539.0182$ $(\mathrm{M})^{-}$.

IR ( $\mathrm{cm}^{-1}$ ): 953 and 797, 786, 777 (X-sensitive), $\mathrm{C}_{6} \mathrm{~F}_{5} \cdot{ }^{73}{ }^{1} \mathrm{H}$ NMR (acetone- $d_{6}, 298$ $\mathrm{K}, 400 \mathrm{MHz}$ ), $\delta: 8.30\left(\mathrm{~d},{ }^{3} J_{\mathrm{H}, \mathrm{H}}=4.8 \mathrm{~Hz}, 2 \mathrm{~m}-\mathrm{H}\right.$ of $\mathrm{C}_{4} \mathrm{H}_{3} \mathrm{~N}_{2}$ ), $8.13\left(\mathrm{dd},{ }^{3} J_{\mathrm{H}, \mathrm{P}}=10.8 \mathrm{~Hz}\right.$, ${ }^{3} J_{\mathrm{H}, \mathrm{H}}=7.8 \mathrm{~Hz}, 4$ ortho-H of $\mathrm{Ph}_{2} \mathrm{P}^{2} \mathrm{~S}$ ), 7.54 (m, overlapped 4 ortho- $\mathrm{H}$ of $\mathrm{Ph}_{2} \mathrm{P}^{1}+2$ para$\mathrm{H}$ of $\mathrm{Ph}_{2} \mathrm{P}^{2} \mathrm{~S}$ ), 7.41 (pseudo td, ${ }^{3} J_{\mathrm{H}, \mathrm{H}}=7.8 \mathrm{~Hz},{ }^{4} J_{\mathrm{H}, \mathrm{P}}=2.0 \mathrm{~Hz}, 4$ meta-H of $\mathrm{Ph}_{2} \mathrm{P}^{2} \mathrm{~S}$ ), 7.21 $\left(\mathrm{t},{ }^{3} J_{\mathrm{H}, \mathrm{H}}=4.8 \mathrm{~Hz}, 1\right.$ p-H of $\left.\mathrm{C}_{4} \mathrm{H}_{3} \mathrm{~N}_{2}\right), 7.15\left(\mathrm{t},{ }^{3} J_{\mathrm{H}, \mathrm{H}}=7.0 \mathrm{~Hz}, 2\right.$ para- $\mathrm{H}$ of $\left.\mathrm{Ph}_{2} \mathrm{P}^{1}\right), 7.03(\mathrm{t}$, ${ }^{3} J_{\mathrm{H}, \mathrm{H}}=7.0 \mathrm{~Hz}, 4$ meta-H of $\left.\mathrm{Ph}_{2} \mathrm{P}^{1}\right), 3.51\left(\mathrm{~m}, 8 \mathrm{H}, \mathrm{NBu}_{4}{ }^{+}\right), 1.88\left(\mathrm{~m}, 8 \mathrm{H}, \mathrm{NBu}_{4}{ }^{+}\right), 1.49$ (pseudo sextet, $8 \mathrm{H},{ }^{3} J_{\mathrm{H}, \mathrm{H}}=7.2 \mathrm{~Hz}, \mathrm{NBu}_{4}{ }^{+}$), $1.03\left(\mathrm{t}, 12 \mathrm{H},{ }^{3} J_{\mathrm{H}, \mathrm{H}}=7.2 \mathrm{NBu}_{4}{ }^{+}\right) .{ }^{19} \mathrm{~F} \mathrm{NMR}$ (acetone- $\left.d_{6}, 298 \mathrm{~K}, 376.5 \mathrm{MHz}\right), \delta:-115.3$ (d, ${ }^{3} J_{\mathrm{Pt}, \mathrm{F}}=334 \mathrm{~Hz}, 2$ ortho-F), -115.5 (m, overlapped 4 ortho-F of $\mathrm{C}_{6} \mathrm{~F}_{5}$ rings trans to $\mathrm{P}$ atoms), -116.4 (m, ${ }^{3} \mathrm{~J}_{\mathrm{Pt}, \mathrm{F}}=448 \mathrm{~Hz}, 2$ ortho-F of the $\mathrm{C}_{6} \mathrm{~F}_{5}$ trans to $\left.\mathrm{S}\right),-165.3\left(\mathrm{t},{ }^{3} J_{\mathrm{F}, \mathrm{F}}=19.8 \mathrm{~Hz}, 1\right.$ para-F), $-165.8\left(\mathrm{t},{ }^{3} J_{\mathrm{F}, \mathrm{F}}=\right.$ $19.8 \mathrm{~Hz}, 1$ para-F), -165.9 (pseudo td, ${ }^{3} J_{\mathrm{F}, \mathrm{F}}=19.8 \mathrm{~Hz},{ }^{5} J_{\mathrm{F}, \mathrm{P}}=6.8 \mathrm{~Hz}, 2$ meta-F), -166.5 (pseudo td, ${ }^{3} J_{\mathrm{F}, \mathrm{F}}=21.6 \mathrm{~Hz},{ }^{5} J_{\mathrm{F}, \mathrm{P}}=8.5 \mathrm{~Hz}, 2$ meta-F), from -166.7 to $-166.9(\mathrm{~m}$, overlapped 2 meta-F +1 para-F), $-167.5\left(\mathrm{t},{ }^{3} J_{\mathrm{F}, \mathrm{F}}=21.8 \mathrm{~Hz},{ }^{4} J_{\mathrm{F}, \mathrm{Pt}}=120 \mathrm{~Hz}, 2\right.$ meta-F of the $\mathrm{C}_{6} \mathrm{~F}_{5}$ trans to $\left.\mathrm{S}\right),-167.8\left(\mathrm{t},{ }^{3} \mathrm{~J}_{\mathrm{F}, \mathrm{F}}=21.8 \mathrm{~Hz}, 1\right.$ para-F of the $\mathrm{C}_{6} \mathrm{~F}_{5}$ trans to $\left.\mathrm{S}\right) .{ }^{31} \mathrm{P}\left\{{ }^{1} \mathrm{H}\right\}$ NMR (acetone- $\left.d_{6}, 298 \mathrm{~K}, 162.0 \mathrm{MHz}\right), \delta: 101.0\left({ }^{1} J_{\mathrm{P} 2, \mathrm{Pt} 1}=2684 \mathrm{~Hz}, \mathrm{P}^{2}\right),-18.9\left({ }^{1} J_{\mathrm{P} 1, \mathrm{Pt} 1}=\right.$ $1846 \mathrm{~Hz},{ }^{1} J_{\mathrm{P} 1, \mathrm{Pt} 2}=1898 \mathrm{~Hz}, \mathrm{P}^{1}$ ). ${ }^{195} \mathrm{Pt}$ NMR (acetone- $d_{6}, 298 \mathrm{~K}, 86 \mathrm{MHz}$ ), $\delta:-4491$ $\left(\mathrm{Pt}^{1}\right),-4290\left(\mathrm{Pt}^{2}\right)$.

$\left[\mathrm{N}^{\mathrm{n}} \mathrm{Bu}_{4}\right]\left[\left(\mathrm{C}_{6} \mathrm{~F}_{5}\right)_{2} \mathrm{Pt}\left(\boldsymbol{\mu}-\mathrm{PPh}_{2}\right)\left(\mu-\mathrm{Ph}_{2} \mathrm{P}-\mathrm{SC}_{5} \mathrm{H}_{4} \mathrm{~N}\right) \operatorname{Pt}\left(\mathrm{C}_{6} \mathrm{~F}_{5}\right)_{2}\right](5)$ 
To a yellow solution of $1(0.140 \mathrm{~g}, 0.098 \mathrm{mmol})$ in acetone $(25 \mathrm{~mL}) 0.100 \mathrm{mmol}$ of $\mathrm{N}^{\mathrm{n}} \mathrm{Bu}_{4} \mathrm{SC}_{6} \mathrm{H}_{4} \mathrm{~N}$ in methanol solution (the solution was prepared through the addition of $\mathrm{MeOH}$ to equimolar amounts of $\mathrm{C}_{5} \mathrm{H}_{4} \mathrm{NSH}$ and of a commercial $\mathrm{N}^{\mathrm{n}} \mathrm{Bu}_{4} \mathrm{OH} 1.0 \mathrm{M}$ methanol solution) were added. The solution was stirred at room temperature for $20 \mathrm{~h}$ and the resulting colourless solution was evaporated to ca. $1 \mathrm{~mL}$. ${ }^{\mathrm{i}} \mathrm{PrOH}(3 \mathrm{~mL})$ was added and 5 crystallised as a white solid which was filtered, washed with ${ }^{\mathrm{i}} \mathrm{PrOH}(3 \times 0.5$ $\mathrm{mL}$ ) and dried in vacuum. Yield: $0.115 \mathrm{~g}, 66 \%$ Anal. Found (calcd for $\mathrm{C}_{68} \mathrm{~F}_{20} \mathrm{H}_{60} \mathrm{~N}_{2} \mathrm{P}_{2} \mathrm{Pt}_{2} \mathrm{~S}$ ): C, 46.48 (46.16); H, 3.53 (3.42); N, 1.48 (1.58); S, 2.14 (1.81). HRMS(-), exact mass for the anion [M] : 1538.0079 Da; measured: m/z: 1538.0019 $(\mathrm{M})^{-}$.

IR $\left(\mathrm{cm}^{-1}\right.$ ): 952 and 799, 789, 776 (X-sensitive), $\mathrm{C}_{6} \mathrm{~F}_{5} \cdot{ }^{73}{ }^{1} \mathrm{H}$ NMR (acetone- $d_{6}, 298 \mathrm{~K}$, $400 \mathrm{MHz}), \delta: 8.13\left(\mathrm{dd},{ }^{3} J_{\mathrm{H}, \mathrm{H}}=4.5 \mathrm{~Hz},{ }^{4} J_{\mathrm{H}, \mathrm{H}}=1.8 \mathrm{~Hz}, 1\right.$ meta-H $[\mathrm{NCH}]$ of $\left.\mathrm{C}_{5} \mathrm{H}_{4} \mathrm{~N}\right), 7.76$ and 7.73 (m, partially overlapped 4 ortho- $\mathrm{H}$ of $\mathrm{Ph}_{2} \mathrm{P}^{2} \mathrm{~S}+4$ ortho- $\mathrm{H}$ of $\mathrm{Ph}_{2} \mathrm{P}^{1}$ ), 7.55 (pseudo td, ${ }^{3} J_{\mathrm{H}, \mathrm{H}}=7.5 \mathrm{~Hz}, 2$ para- $\mathrm{H}$ of $\mathrm{Ph}_{2} \mathrm{P}^{2} \mathrm{~S}$ ), 7.39 (pseudo td, ${ }^{3} J_{\mathrm{H}, \mathrm{H}}=7.5 \mathrm{~Hz},{ }^{4} J_{\mathrm{H}, \mathrm{P}}=$ $2.8 \mathrm{~Hz}, 4$ meta-H of $\mathrm{Ph}_{2} \mathrm{P}^{2} \mathrm{~S}$ ), 7.22 (partially overlapped pseudo td, ${ }^{3} J_{\mathrm{H}, \mathrm{H}}=7.6 \mathrm{~Hz},{ }^{4} J_{\mathrm{H}, \mathrm{H}}$ $=1.8 \mathrm{~Hz}, 1$ meta $-\mathrm{H}[\mathrm{CCH}]$ of $\left.\mathrm{C}_{5} \mathrm{H}_{4} \mathrm{~N}\right), 7.19$ (m, overlapped 2 para $-\mathrm{H}$ of $\mathrm{Ph}_{2} \mathrm{P}^{1}+1$ para$\mathrm{H}$ of $\mathrm{C}_{5} \mathrm{H}_{4} \mathrm{~N}$ ), 7.11 (pseudo td, ${ }^{3} J_{\mathrm{H}, \mathrm{H}}=7.6 \mathrm{~Hz},{ }^{4} J_{\mathrm{H}, \mathrm{P}}=1.6 \mathrm{~Hz}, 4$ meta- $\mathrm{H}$ of $\mathrm{Ph}_{2} \mathrm{P}^{1}$ ), 6.70 $\left(\mathrm{d},{ }^{3} J_{\mathrm{H}, \mathrm{H}}=7.6 \mathrm{~Hz}, 1\right.$ ortho-H of $\left.\mathrm{C}_{5} \mathrm{H}_{4} \mathrm{~N}\right), 3.51\left(\mathrm{~m}, 8 \mathrm{H}, \mathrm{NBu}_{4}{ }^{+}\right), 1.88\left(\mathrm{~m}, 8 \mathrm{H}, \mathrm{NBu}_{4}{ }^{+}\right)$, 1.49 (pseudo sextet, $8 \mathrm{H},{ }^{3} J_{\mathrm{H}, \mathrm{H}}=7.6 \mathrm{~Hz}, \mathrm{NBu}_{4}{ }^{+}$), $1.03\left(\mathrm{t}, 12 \mathrm{H},{ }^{3} J_{\mathrm{H}, \mathrm{H}}=7.2 \mathrm{~Hz}, 12 \mathrm{H}\right.$, $\left.\mathrm{NBu}_{4}{ }^{+}\right) .{ }^{19} \mathrm{~F}$ NMR (acetone- $d_{6}, 298 \mathrm{~K}, 376.5 \mathrm{MHz}$ ), $\delta:-115.4\left(\mathrm{~m},{ }^{3} J_{\mathrm{Pt}, \mathrm{F}}=348 \mathrm{~Hz}, 2\right.$ ortho-F), -115.9 ( $\mathrm{m}$, satellite signals appear overlapped and ${ }^{3} J_{\mathrm{Pt}, \mathrm{F}}$ is not measured, 2 ortho-F),-116.1 (m, satellite signals appear overlapped and ${ }^{3} J_{\mathrm{Pt}, \mathrm{F}}$ is not measured, 2 ortho-F), -116.4 (m, ${ }^{3} J_{\mathrm{Pt}, \mathrm{F}}=462 \mathrm{~Hz}, 2$ ortho-F of the $\mathrm{C}_{6} \mathrm{~F}_{5}$ trans to $\left.\mathrm{S}\right),-165.0\left(\mathrm{t},{ }^{3} J_{\mathrm{F}, \mathrm{F}}=\right.$ $19.9 \mathrm{~Hz}, 1$ para-F), -165.3 (t, ${ }^{3} J_{\mathrm{F}, \mathrm{F}}=19.6 \mathrm{~Hz}, 1$ para-F), -165.8 (pseudo td, ${ }^{3} J_{\mathrm{F}, \mathrm{F}}=21.3$ $\mathrm{Hz},{ }^{5} J_{\mathrm{F}, \mathrm{P}}=7.8 \mathrm{~Hz}, 2$ meta-F), -166.0 (pseudo td, ${ }^{3} J_{\mathrm{F}, \mathrm{F}}=21.0 \mathrm{~Hz},{ }^{5} J_{\mathrm{F}, \mathrm{P}}=8.0 \mathrm{~Hz}, 2$ metaF), from -166.5 to -166.9 (m, overlapped 2 meta-F +1 para-F), -167.4 (t, ${ }^{3} J_{\mathrm{F}, \mathrm{F}}=19.9$ $\mathrm{Hz},{ }^{4} J_{\mathrm{F}, \mathrm{Pt}}=116 \mathrm{~Hz}, 2$ meta-F of the $\mathrm{C}_{6} \mathrm{~F}_{5}$ trans to $\left.\mathrm{S}\right),-167.7\left(\mathrm{t},{ }^{3} J_{\mathrm{F}, \mathrm{F}}=19.9 \mathrm{~Hz}, 1\right.$ para-F of the $\mathrm{C}_{6} \mathrm{~F}_{5}$ trans to $\mathrm{S}$ ). ${ }^{31} \mathrm{P}\left\{{ }^{1} \mathrm{H}\right\}$ NMR (acetone- $\left.d_{6}, 298 \mathrm{~K}, 162.0 \mathrm{MHz}\right), \delta: 107.0\left({ }^{1} J_{\mathrm{P} 2, \mathrm{Pt} 1}\right.$ $\left.=2693 \mathrm{~Hz}, \mathrm{P}^{2}\right),-12.5\left({ }^{1} J_{\mathrm{P} 1, \mathrm{Pt} 1}=1838 \mathrm{~Hz},{ }^{1} J_{\mathrm{P} 1, \mathrm{Pt} 2}=1893 \mathrm{~Hz}, \mathrm{P}^{1}\right) \mathrm{ppm} .{ }^{195} \mathrm{Pt} \mathrm{NMR}$ (acetone- $\left.d_{6}, 298 \mathrm{~K}, 86 \mathrm{MHz}\right), \delta:-4467\left(\mathrm{Pt}^{1}\right),-4319\left(\mathrm{Pt}^{2}\right)$.

\section{$\left[\mathrm{N}^{\mathrm{n}} \mathrm{Bu}_{4}\right]\left[\left(\mathrm{PPh}_{2} \mathrm{C}_{6} \mathrm{~F}_{5}\right)\left(\mathrm{C}_{6} \mathrm{~F}_{5}\right)_{2} \mathrm{Pt}\left(\mu-\mathrm{PPh} \mathrm{h}_{2}\right) \operatorname{Pt}\left(\mathrm{S}_{2} \mathrm{COEt}\right)\left(\mathrm{C}_{6} \mathrm{~F}_{5}\right)\right](6)$}


To a yellow solution of $1(0.130 \mathrm{~g}, 0.091 \mathrm{mmol})$ in $\mathrm{CH}_{2} \mathrm{Cl}_{2}(20 \mathrm{~mL}) 0.015 \mathrm{~g}(0.093$ mmol) of $\mathrm{KEtOCS}_{2}$ in methanol $(2 \mathrm{~mL})$ were added. The solution was stirred at room temperature for $20 \mathrm{~h}$ and $\mathrm{N}^{\mathrm{n}} \mathrm{Bu}_{4} \mathrm{ClO}_{4}(0.031 \mathrm{~g}, 0.091 \mathrm{mmol})$ was added. The mixture was evaporated almost to dryness and $\mathrm{MeOH}(2 \mathrm{~mL})$ was added. A pale yellow solid crystallized that was filtered and washed with $\mathrm{MeOH}(2 \times 0.5 \mathrm{~mL})$. The solid was treated with $\mathrm{CH}_{2} \mathrm{Cl}_{2}(8 \mathrm{~mL})$ and the resulting suspension was filtered through celite. The filtrate was evaporated to ca. $2 \mathrm{~mL}$ and added of n-hexane $(15 \mathrm{~mL})$. Complex 6 crystallized as a yellow solid which was filtered, washed with n-hexane $(3 \times 1 \mathrm{~mL})$ and dried in vacuum. Yield: $0.090 \mathrm{~g}, 55 \%$. Anal. Found (calcd for $\mathrm{C}_{67} \mathrm{~F}_{20} \mathrm{H}_{61} \mathrm{NOP}_{2} \mathrm{Pt}_{2} \mathrm{~S}_{2}$ ): C, 44.81 (44.90); H, 3.35 (3.43); N 0.54 (0.78); S, 3.77 (3.58). HRMS(-), exact mass for the anion [M] $]^{-}$1548.9795 Da; measured: $\mathrm{m} / \mathrm{z}: 1548.9754(\mathrm{M})^{-}$.

IR ( $\left.\mathrm{cm}^{-1}\right)$ : 1520, $980\left(\mathrm{PPh}_{2} \mathrm{C}_{6} \mathrm{~F}_{5}\right)$; 952 and 792, 779 (X-sensitive), $\mathrm{C}_{6} \mathrm{~F}_{5}{ }^{73}{ }^{1} \mathrm{H} \mathrm{NMR}$ (acetone- $d_{6}, 298 \mathrm{~K}, 400 \mathrm{MHz}$ ), $\delta: 7.84\left(\mathrm{dd},{ }^{3} J_{\mathrm{H}, \mathrm{P}}=12.0 \mathrm{~Hz},{ }^{3} J_{\mathrm{H}, \mathrm{H}}=8.8 \mathrm{~Hz}, 4\right.$ ortho-H of $\left.\mathrm{Ph}_{2}\left(\mathrm{C}_{6} \mathrm{~F}_{5}\right) \mathrm{P}^{2}\right), 7.65\left(\mathrm{t},{ }^{3} J_{\mathrm{H}, \mathrm{H}}=9.0 \mathrm{~Hz}, 4\right.$ ortho- $\mathrm{H}$ of $\left.\mathrm{Ph}_{2} \mathrm{P}^{1}\right), 7.38\left(\mathrm{t},{ }^{3} J_{\mathrm{H}, \mathrm{H}}=7.6 \mathrm{~Hz}, 2\right.$ para$\mathrm{H}$ of $\left.\mathrm{Ph}_{2}\left(\mathrm{C}_{6} \mathrm{~F}_{5}\right) \mathrm{P}^{2}\right), 7.22\left(\mathrm{td},{ }^{3} J_{\mathrm{H}, \mathrm{H}}=7.6 \mathrm{~Hz},{ }^{4} J_{\mathrm{H}, \mathrm{P}}=2.0 \mathrm{~Hz}, 4\right.$ meta-H of $\left.\mathrm{Ph}_{2}\left(\mathrm{C}_{6} \mathrm{~F}_{5}\right) \mathrm{P}^{2}\right)$, $6.96\left(\mathrm{t},{ }^{3} J_{\mathrm{H}, \mathrm{H}}=7.2 \mathrm{~Hz}, 2\right.$ para-H of $\left.\mathrm{Ph}_{2} \mathrm{P}^{1}\right), 6.84\left(\mathrm{t},{ }^{3} J_{\mathrm{H}, \mathrm{H}}=7.2 \mathrm{~Hz}, 4\right.$ meta- $\mathrm{H}$ of $\left.\mathrm{Ph}_{2} \mathrm{P}^{1}\right)$, 4.39 (q, $2 \mathrm{H}, \mathrm{OCH}_{2} \mathrm{CH}_{3}$ ), $3.51\left(\mathrm{~m}, 8 \mathrm{H}, \mathrm{NBu}_{4}{ }^{+}\right)_{2} 1.88\left(\mathrm{~m}, 8 \mathrm{H}, \mathrm{NBu}_{4}{ }^{+}\right.$), 1.49 (pseudo sextet, $\left.8 \mathrm{H},{ }^{3} J_{\mathrm{H}, \mathrm{H}}=7.6 \mathrm{~Hz}, \mathrm{NBu}_{4}{ }^{+}\right), 1.39\left(\mathrm{t}, 3 \mathrm{H}, \mathrm{OCH}_{2} \mathrm{CH}_{3}\right), 1.03\left(\mathrm{t}, 12 \mathrm{H},{ }^{3} J_{\mathrm{H}, \mathrm{H}}=7.2\right.$ $\left.\mathrm{Hz}, 12 \mathrm{H}, \mathrm{NBu}_{4}{ }^{+}\right) .{ }^{19} \mathrm{~F}$ NMR (acetone- $\left.d_{6}, 293 \mathrm{~K}, 376.5 \mathrm{MHz}\right), \delta:-112.9\left(\mathrm{~m},{ }^{3} \mathrm{~J}_{\mathrm{Pt}, \mathrm{F}}=348\right.$ $\mathrm{Hz}, 2$ ortho-F of the $\mathrm{C}_{6} \mathrm{~F}_{5}$ bonded to $\mathrm{Pt}^{1}$ ), -115.8 (m, overlapped, ${ }^{3} J_{\mathrm{Pt}, \mathrm{F}}=412 \mathrm{~Hz},{ }^{3} \mathrm{Jt}_{\mathrm{Pt}, \mathrm{F}}=$ $290 \mathrm{~Hz}, 4$ ortho-F),-122.6 (d, ${ }^{3} J_{\mathrm{F}, \mathrm{F}} 18 \mathrm{~Hz}, 2$ ortho-F of the $\left.\mathrm{Ph}_{2}\left(\mathrm{C}_{6} \mathrm{~F}_{5}\right) \mathrm{P}^{2}\right),-154.0\left(\mathrm{t},{ }^{3} J_{\mathrm{F}, \mathrm{F}}\right.$ $=20.0 \mathrm{~Hz}, 1$ para-F of the $\mathrm{Ph}_{2}\left(\mathrm{C}_{6} \mathrm{~F}_{5}\right) \mathrm{P}^{2}$ ), -164.1 (pseudo t, ${ }^{3} J_{\mathrm{F}, \mathrm{F}}=19.6 \mathrm{~Hz}, 2$ meta-F of the $\mathrm{Ph}_{2}\left(\mathrm{C}_{6} \mathrm{~F}_{5}\right) \mathrm{P}^{2}$ ), $-165.8\left(\mathrm{t},{ }^{3} J_{\mathrm{F}, \mathrm{F}}=19.9 \mathrm{~Hz}, 1\right.$ para-F), -166.1 (pseudo td, ${ }^{3} J_{\mathrm{F}, \mathrm{F}}=22.0$ $\mathrm{Hz},{ }^{5} J_{\mathrm{F}, \mathrm{P}}=8.3 \mathrm{~Hz}, 2$ meta-F), -167.0 (pseudo td, ${ }^{3} J_{\mathrm{F}, \mathrm{F}}=20.9 \mathrm{~Hz},{ }^{5} J_{\mathrm{F}, \mathrm{P}}=9.4 . \mathrm{Hz}, 2$ metaF), -167.3 (pseudo td, ${ }^{4} J_{\mathrm{F}, \mathrm{Pt}}=112 \mathrm{~Hz},{ }^{3} J_{\mathrm{F}, \mathrm{F}}=20.9 \mathrm{~Hz}, 2$ meta-F of the $\mathrm{C}_{6} \mathrm{~F}_{5}$ trans to $\mathrm{S}$ ), $-167.8\left(\mathrm{t},{ }^{3} J_{\mathrm{F}, \mathrm{F}}=19.5 \mathrm{~Hz}, 1\right.$ para-F of the $\mathrm{C}_{6} \mathrm{~F}_{5}$ trans to $\left.\mathrm{S}\right),-168.0\left(\mathrm{t},{ }^{3} \mathrm{~J}_{\mathrm{F}, \mathrm{F}}=19.5 \mathrm{~Hz}, 1\right.$ para-F). ${ }^{31} \mathrm{P}\left\{{ }^{1} \mathrm{H}\right\}$ NMR (acetone- $\left.d_{6}, 298 \mathrm{~K}, 162.0 \mathrm{MHz}\right), \delta: 9.7\left({ }^{1} J_{\mathrm{P} 2, \mathrm{Pt} 1}=2565 \mathrm{~Hz}, \mathrm{P}^{2}\right)$, $-20.7\left({ }^{1} J_{\mathrm{P} 1, \mathrm{Pt} 1}=2003 \mathrm{~Hz},{ }^{1} J_{\mathrm{P} 1, \mathrm{Pt} 2}=2972 \mathrm{~Hz}, \mathrm{P}^{1}\right) \mathrm{ppm} .{ }^{195} \mathrm{Pt}$ NMR (acetone- $d_{6}, 298 \mathrm{~K}, 86$ $\mathrm{MHz}), \delta:-4427\left(\mathrm{Pt}^{1}\right),-4310\left(\mathrm{Pt}^{2}\right)$.

\section{$\left[\mathrm{N}^{\mathrm{n}} \mathrm{Bu}_{4}\right]\left[\left(\mathrm{PPh}_{2} \mathrm{C}_{6} \mathrm{~F}_{5}\right)\left(\mathrm{C}_{6} \mathrm{~F}_{5}\right)_{2} \operatorname{Pt}\left(\boldsymbol{\mu}-\mathrm{PPh}_{2}\right) \operatorname{Pt}(\mathrm{pymS})\left(\mathrm{C}_{6} \mathrm{~F}_{5}\right)\right](7)$}

To a yellow solution of $1(0.150 \mathrm{~g}, 0.105 \mathrm{mmol})$ in $\mathrm{CH}_{2} \mathrm{Cl}_{2}(25 \mathrm{~mL}) 0.105 \mathrm{mmol}$ of $\mathrm{N}^{\mathrm{n}} \mathrm{Bu}_{4} \mathrm{SC}_{4} \mathrm{H}_{3} \mathrm{~N}_{2}$ in methanol solution (the solution was prepared through the addition of 
$\mathrm{MeOH}$ to equimolar amounts of $\mathrm{C}_{4} \mathrm{H}_{3} \mathrm{~N}_{2} \mathrm{SH}$ and of a commercial $\mathrm{N}^{n} \mathrm{Bu}_{4} \mathrm{OH} 1.0 \mathrm{M}$ methanol solution) were added. The solution was stirred at room temperature for $20 \mathrm{~h}$ and the resulting pale yellow solution was evaporated to dryness. After addition of nhexane (30 mL) to the yellow residue, the resulting suspension was stirred for $15 \mathrm{~h}$, then the formed yellow solid, complex 7, was filtered out and dried under vacuum. Yield: 0.164 g. Anal. Found (calcd for $\mathrm{C}_{68} \mathrm{~F}_{20} \mathrm{H}_{59} \mathrm{~N}_{3} \mathrm{P}_{2} \mathrm{Pt}_{2} \mathrm{~S}$ ): C, 46.21 (45.82); H, 3.73 (3.34); N, 2.44 (2.36); S, 2.22 (1.80). HRMS(-), exact mass for the anion [M]-: $1539.0031 \mathrm{Da}$; measured: m/z: $1539.0001(\mathrm{M})^{-}$.

IR ( $\left.\mathrm{cm}^{-1}\right)$ : 1521, $980\left(\mathrm{PPh}_{2} \mathrm{C}_{6} \mathrm{~F}_{5}\right)$; 955 and 802, 791, 778 (X-sensitive), $\mathrm{C}_{6} \mathrm{~F}_{5}{ }^{73}{ }^{1} \mathrm{H}$ NMR (acetone- $\left.d_{6}, 298 \mathrm{~K}, 400 \mathrm{MHz}\right), \delta: 8.20\left(\mathrm{dd},{ }^{3} J_{\mathrm{H}, \mathrm{H}}=4.7 \mathrm{~Hz},{ }^{4} J_{\mathrm{H}, \mathrm{H}}=2.3 \mathrm{~Hz}, \mathrm{H}\right.$ of $\mathrm{C}_{4} \mathrm{~N}_{2}$ ring in para position to $\mathrm{N}^{1}$ ),7.44 (broad), 7.29 (broad), 6.38 (dd, ${ }^{3} J_{\mathrm{H}, \mathrm{H}}=4.7 \mathrm{~Hz}, \mathrm{H}$ of $\mathrm{C}_{4} \mathrm{~N}_{2}$ ring in para position to $\left.\mathrm{C}^{39}\right), 3.51\left(\mathrm{~m}, 8 \mathrm{H}, \mathrm{NBu}_{4}{ }^{+}\right)_{2} 1.88\left(\mathrm{~m}, 8 \mathrm{H}, \mathrm{NBu}_{4}{ }^{+}\right), 1.49$ (pseudo sextet, $8 \mathrm{H},{ }^{3} J_{\mathrm{H}, \mathrm{H}}=7.6 \mathrm{~Hz}, \mathrm{NBu}_{4}{ }^{+}$), $1.03\left(\mathrm{t}, 12 \mathrm{H},{ }^{3} J_{\mathrm{H}, \mathrm{H}}=7.2 \mathrm{~Hz}, 12 \mathrm{H}_{,} \mathrm{NBu}_{4}{ }^{+}\right.$). ${ }^{1} \mathrm{H}$ NMR (acetone- $d_{6}, 198 \mathrm{~K}, 400 \mathrm{MHz}$ ): conformer A: 9.36 (broad, 1 ortho-H of the $\mathrm{PPh}_{2}$ ), from 8.3 to 8.18 (overlapped, $1 \mathrm{H} \mathrm{C}^{49}-\mathrm{N}^{2}-\mathrm{CH}+1$ ortho- $\mathrm{H}$ of the $\mathrm{PPh}_{2}$ ), 7.86 (broad, 1 para- $\mathrm{H}$ of the $\mathrm{PPh}_{2}\left(\mathrm{C}_{6} \mathrm{~F}_{5}\right)$ ), 7.65 (broad and partially overlapped, 1 meta-H of the $\mathrm{PPh}_{2}$ ), 7.55 (broad, 1 para-H of the $\mathrm{PPh}_{2}$ ) 7.36 (broad and partially overlapped, 1 meta- $\mathrm{H}$ of the $\mathrm{PPh}_{2}$ ), 7.25 (broad, 1 para-H of the $\mathrm{PPh}_{2}\left(\mathrm{C}_{6} \mathrm{~F}_{5}\right)$ ), 6.77 (broad, 1 para- $\mathrm{H}$ of the $\mathrm{PPh}_{2}$ ), 6.67 (broad, 1 meta-H of the $\mathrm{PPh}_{2}$ ), 6.39 (broad, $1 \mathrm{H}, \mathrm{C}^{49}-\mathrm{N}-\mathrm{CH}-\mathrm{CH}$ ), 6.34 (broad, 1 overlapped ortho- $\mathrm{H}$ of the $\mathrm{PPh}_{2}$ ), 6.23 (broad, 1 ortho- $\mathrm{H}$ of the $\mathrm{PPh}_{2}$ ), 6.00 (broad, 1 meta-H of the $\mathrm{PPh}_{2}$ ), 5.27 (broad, $1 \mathrm{H}, \mathrm{C}^{49}-\mathrm{N}^{1}-\mathrm{CH}$ ), $3.45\left(\mathrm{~m}, 8 \mathrm{H}, \mathrm{NBu}_{4}{ }^{+}\right.$), $1.78\left(\mathrm{~m}, 8 \mathrm{H}, \mathrm{NBu}_{4}{ }^{+}\right), 1.36$ (pseudo sextet, $\left.8 \mathrm{H},{ }^{3} J_{\mathrm{H}, \mathrm{H}}=7.6 \mathrm{~Hz}, \mathrm{NBu}_{4}^{+}\right), 0.93(\mathrm{t}, 12 \mathrm{H}$, $\left.{ }^{3} J_{\mathrm{H}, \mathrm{H}}=7.2 \mathrm{~Hz}, 12 \mathrm{H}, \mathrm{NBu}_{4}^{+}\right)$. The remaining 8 protons of the $\mathrm{PPh}_{2}\left(\mathrm{C}_{6} \mathrm{~F}_{5}\right)$ give an unresolved very broad signal ranging from 8.0 to $5.5 \mathrm{ppm}$. The unequivocal attribution of the ${ }^{1} \mathrm{H}$ NMR signals of conformer $B$ was hampered by their relatively low intensity and high broadness. ${ }^{19} \mathrm{~F}$ NMR (acetone- $d_{6}, 298 \mathrm{~K}, 376.5 \mathrm{MHz}$ ), $\delta$ :-105.3 (very broad, 2 ortho-F of the $\mathrm{C}_{6} \mathrm{~F}_{5}$ bonded to $\mathrm{Pt}^{1}$ and trans to $\mathrm{P}^{2}$ ) from -113 to -119 (broad overlapped signals of 2 ortho-F of the $\mathrm{C}_{6} \mathrm{~F}_{5}$ ring bonded to $\mathrm{Pt}^{1}$ and trans to $\mathrm{P}^{1}+2$ ortho- $\mathrm{F}$ of the $\mathrm{C}_{6} \mathrm{~F}_{5}$ ring bonded to $\mathrm{Pt}^{2}$ ) -122.8 (very broad, 2 ortho- $\mathrm{F}$ of the $\left.\mathrm{Ph}_{2}\left(\mathrm{C}_{6} \mathrm{~F}_{5}\right) \mathrm{P}\right)$. ${ }^{19} \mathrm{~F}$ NMR (acetone- $d_{6}, 198 \mathrm{~K}, 376.5 \mathrm{MHz}$ ), $\delta:-102.3$ (broad, ${ }^{3} J_{\mathrm{Pt}, \mathrm{F}}=$ ca. $340 \mathrm{~Hz}, 1$ ortho-F of the $\mathrm{C}_{6} \mathrm{~F}_{5}$ bonded to $\mathrm{Pt}^{1}$ and trans to $\mathrm{P}^{2}$ of conformer A), -102.5 (broad, ${ }^{3} J_{\mathrm{Pt}, \mathrm{F}}=$ ca. $340 \mathrm{~Hz}, 1$ ortho-F of the $\mathrm{C}_{6} \mathrm{~F}_{5}$ bonded to $\mathrm{Pt}^{1}$ and trans to $\mathrm{P}^{2}$ of conformer $\mathrm{A}$ ), -105.4 (broad, ${ }^{3} \mathrm{~J}_{\mathrm{Pt}, \mathrm{F}}$ = ca. $340 \mathrm{~Hz}, 2$ ortho-F of the $\mathrm{C}_{6} \mathrm{~F}_{5}$ bonded to $\mathrm{Pt}^{1}$ and trans to $\mathrm{P}^{2}$ of conformer $\mathrm{B}$ ) from 
-113 to -120 (broad overlapped signals of 2 ortho-F of the $\mathrm{C}_{6} \mathrm{~F}_{5}$ ring bonded to $\mathrm{Pt}^{1}$ and trans to $\mathrm{P}^{1}+2$ ortho- $\mathrm{F}$ of the $\mathrm{C}_{6} \mathrm{~F}_{5}$ ring bonded to $\mathrm{Pt}^{2}$ of conformers $\mathrm{A}$ and $\left.\mathrm{B}\right)-122.4$ (broad, 1 ortho-F of the $\mathrm{Ph}_{2}\left(\mathrm{C}_{6} \mathrm{~F}_{5}\right) \mathrm{P}$ of conformer $\mathrm{B}$ ), -124.1 (broad, 2 ortho-F of the $\mathrm{Ph}_{2}\left(\mathrm{C}_{6} \mathrm{~F}_{5}\right) \mathrm{P}$ of conformer $\mathrm{A}$ ), -128.2 (broad, 1 ortho-F of the $\mathrm{Ph}_{2}\left(\mathrm{C}_{6} \mathrm{~F}_{5}\right) \mathrm{P}$ of conformer B).

${ }^{31} \mathrm{P}\left\{{ }^{1} \mathrm{H}\right\}$ NMR (acetone- $\left.d_{6}, 298 \mathrm{~K}, 162.0 \mathrm{MHz}\right), \delta: 9.7\left({ }^{1} J_{\mathrm{P} 2, \mathrm{Pt} 1}=2602 \mathrm{~Hz}, \mathrm{P}^{2}\right),-17.7$ $\left({ }^{1} J_{\mathrm{P} 1, \mathrm{Pt} 1}=1957 \mathrm{~Hz},{ }^{1} J_{\mathrm{P} 1, \mathrm{Pt} 2}=2729 \mathrm{~Hz}, \mathrm{P}^{1}\right) \mathrm{ppm} .{ }^{31} \mathrm{P}\left\{{ }^{1} \mathrm{H}\right\}$ NMR (acetone-d $6,198 \mathrm{~K}$, 162.0 MHz), $\delta: 10.2\left({ }^{1} J_{\mathrm{P} 2, \mathrm{P} 11}=2599 \mathrm{~Hz}, \mathrm{P}^{2}\right.$ of conformer A), $14.0\left({ }^{1} J_{\mathrm{P} 2, \mathrm{P} 11}=2613 \mathrm{~Hz}, \mathrm{P}^{2}\right.$ of conformer B), $-18.5\left({ }^{1} J_{\mathrm{P} 1, \mathrm{Pt} 1}=1964 \mathrm{~Hz},{ }^{1} J_{\mathrm{P} 1, \mathrm{Pt} 2}=2773 \mathrm{~Hz}, \mathrm{P}^{1}\right.$ of conformer A) -19.2 $\left({ }^{1} J_{\mathrm{P} 1, \mathrm{Pt} 1}=2015 \mathrm{~Hz},{ }^{1} J_{\mathrm{P} 1, \mathrm{Pt} 2}=2671 \mathrm{~Hz}, \mathrm{P}^{1}\right.$ of conformer B) ppm. ${ }^{195} \mathrm{Pt}$ NMR (acetone- $d_{6}$, $198 \mathrm{~K}, 86 \mathrm{MHz}), \delta:-4449\left(\mathrm{Pt}^{1}\right),-4431\left(\mathrm{Pt}^{2}\right)$.

\section{$\left[\left(\mathbf{P P h}_{2} \mathbf{R}_{\mathrm{F}}\right)\left(\mathrm{CH}_{3} \mathrm{CN}\right)\left(\mathrm{R}_{\mathrm{F}}\right) \mathrm{Pt}^{\mathrm{II}}\left(\mu-\mathrm{PPh}_{2}\right) \mathrm{Pt}^{\mathrm{II}}\left(\mathrm{R}_{\mathrm{F}}\right)_{2}\left(\mathrm{CH}_{3} \mathrm{CN}\right)\right](8)$}

To a yellow suspension of 1 (0.100 g, $0.074 \mathrm{mmol})$ in $\mathrm{CH}_{2} \mathrm{Cl}_{2}(2 \mathrm{~mL}) 0.5 \mathrm{~mL}$ of $\mathrm{CH}_{3} \mathrm{CN}$ was added. The mixture was stirred for $2 \mathrm{~h}$, during which it became a colourless solution. Addition of $n$-hexane (30 mL) caused the precipitation of white crystals, which were filtered, washed with $n$-hexane $(3 \times 1 \mathrm{~mL})$ and dried under vacuum. Yield: 0.093 g, 88\%. Anal. Found (calcd for $\mathrm{C}_{52} \mathrm{~F}_{20} \mathrm{H}_{26} \mathrm{~N}_{2} \mathrm{P}_{2} \mathrm{Pt}_{2}$ ): C, 40.97 (41.34); H, 1.44 (1.73); $\mathrm{N}$ 1.82 (1.85). HRMS(-), exact mass for the anion $\left[\mathrm{M}-\mathrm{CH}_{3} \mathrm{CN}\right]^{-}: 1492.0162 \mathrm{Da}$; measured: $\mathrm{m} / \mathrm{z}: 1492.0099\left(\mathrm{M}-\mathrm{CH}_{3} \mathrm{CN}\right)^{-}$. IR $\left(\mathrm{cm}^{-1}\right)$ : 1519, $982\left(\mathrm{PPh}_{2} \mathrm{C}_{6} \mathrm{~F}_{5}\right) ; 954$ and 805, 781 (X-sensitive), $\mathrm{C}_{6} \mathrm{~F}_{5} \cdot{ }^{73}$ 2323, $2296(\mathrm{C} \equiv \mathrm{N}) .{ }^{1} \mathrm{H}$ NMR (acetone- $d_{6}, 298 \mathrm{~K}, 400$ MHz), $\delta: 7.90\left(\mathrm{dd},{ }^{3} J_{\mathrm{H}, \mathrm{P}}=11.0 \mathrm{~Hz},{ }^{3} J_{\mathrm{H}, \mathrm{H}}=7.9 \mathrm{~Hz}, 4\right.$ ortho- $\mathrm{H}$ of $\left.\mathrm{Ph}_{2}\left(\mathrm{C}_{6} \mathrm{~F}_{5}\right) \mathrm{P}^{2}\right)$, from 7.73 to 7.58 (m, overlapped, 2 para- $\mathrm{H}$ of $\mathrm{Ph}_{2}\left(\mathrm{C}_{6} \mathrm{~F}_{5}\right) \mathrm{P}^{2}+4$ meta- $\mathrm{H}$ of $\mathrm{Ph}_{2}\left(\mathrm{C}_{6} \mathrm{~F}_{5}\right) \mathrm{P}^{2}+4$ ortho- $\mathrm{H}$ of $\left.\mathrm{Ph}_{2} \mathrm{P}^{1}\right), 7.25\left(\mathrm{t},{ }^{3} J_{\mathrm{H}, \mathrm{H}}=7.3 \mathrm{~Hz}, 2\right.$ para- $\mathrm{H}$ of $\left.\mathrm{Ph}_{2} \mathrm{P}^{1}\right), 7.16\left(\mathrm{t},{ }^{3} J_{\mathrm{H}, \mathrm{H}}=7.3 \mathrm{~Hz}, 4\right.$ meta-H of $\mathrm{Ph}_{2} \mathrm{P}^{1}$ ), 2.33 (s, $3 \mathrm{H}$ of $\mathrm{CH}_{3} \mathrm{CN}$ ), 2.16 (s, $3 \mathrm{H}$ of $\mathrm{CH}_{3} \mathrm{CN}$ ). ${ }^{19} \mathrm{~F}$ NMR (acetone- $d_{6}, 293$ $\mathrm{K}, 376.5 \mathrm{MHz}$ ), $\delta:-118.1\left(\mathrm{~d},{ }^{3} J_{\mathrm{Pt}, \mathrm{F}}=502 \mathrm{~Hz},{ }^{3} J_{\mathrm{F}, \mathrm{F}}=20 \mathrm{~Hz}, 2\right.$ ortho-F of the $\mathrm{C}_{6} \mathrm{~F}_{5}$ trans to a $\mathrm{MeCN}),-118.6\left(\mathrm{~m},{ }^{3} \mathrm{~J}_{\mathrm{Pt}, \mathrm{F}}=358 \mathrm{~Hz}, 2\right.$ ortho-F of the $\mathrm{C}_{6} \mathrm{~F}_{5}$ trans to $\left.\mathrm{P}^{1}\right),-118.8(\mathrm{~d}$, ${ }^{3} J_{\mathrm{Pt}, \mathrm{F}}=445 \mathrm{~Hz},{ }^{3} J_{\mathrm{F}, \mathrm{F}}=23 \mathrm{~Hz}, 2$ ortho-F of the $\mathrm{C}_{6} \mathrm{~F}_{5}$ trans to a MeCN), $-125.3\left(\mathrm{~d},{ }^{3} J_{\mathrm{F}, \mathrm{F}}\right.$ $20 \mathrm{~Hz}, 2$ ortho-F of the $\left.\mathrm{Ph}_{2}\left(\mathrm{C}_{6} \mathrm{~F}_{5}\right) \mathrm{P}^{2}\right),-149.7\left(\mathrm{tt},{ }^{3} J_{\mathrm{F}, \mathrm{F}}=20.0 \mathrm{~Hz},{ }^{4} J_{\mathrm{F}, \mathrm{F}}=4.3 \mathrm{~Hz}, 1\right.$ para$\mathrm{F}$ of the $\left.\mathrm{Ph}_{2}\left(\mathrm{C}_{6} \mathrm{~F}_{5}\right) \mathrm{P}^{2}\right),-162.0\left(\mathrm{~m},{ }^{3} J_{\mathrm{F}, \mathrm{F}}=19.6 \mathrm{~Hz},{ }^{4} J_{\mathrm{F}, \mathrm{F}}=4.7 \mathrm{~Hz}, 2\right.$ meta-F of the $\left.\mathrm{Ph}_{2}\left(\mathrm{C}_{6} \mathrm{~F}_{5}\right) \mathrm{P}^{2}\right),-164.8\left(\mathrm{t},{ }^{3} J_{\mathrm{F}, \mathrm{F}}=19.7 \mathrm{~Hz}, 1\right.$ para-F), $-165.4\left(\mathrm{tt},{ }^{3} J_{\mathrm{F}, \mathrm{F}}=19.5 \mathrm{~Hz},{ }^{4} J_{\mathrm{F}, \mathrm{F}}=2.5\right.$ $\mathrm{Hz}, 1$ para-F), -165.8 (overlapped, 4 meta-F), -167.5 (t, ${ }^{3} J_{\mathrm{F}, \mathrm{F}}=19.5 \mathrm{~Hz}, 1$ para-F, $167.7\left(\mathrm{t},{ }^{4} J_{\mathrm{F}, \mathrm{Pt}}=120 \mathrm{~Hz},{ }^{3} J_{\mathrm{F}, \mathrm{F}}=19.5 \mathrm{~Hz}, 2\right.$ meta-F). ${ }^{31} \mathrm{P}\left\{{ }^{1} \mathrm{H}\right\}$ NMR (acetone- $d_{6}, 298 \mathrm{~K}$, 
162.0 MHz), $\delta$ : $4.2\left({ }^{1} J_{\mathrm{P} 2, \mathrm{Pt} 1}=2084 \mathrm{~Hz},{ }^{2} J_{\mathrm{P} 1, \mathrm{P} 2}=313 \mathrm{~Hz}, \mathrm{P}^{2}\right), 1.8\left({ }^{1} J_{\mathrm{P} 1, \mathrm{Pt} 1}=2110 \mathrm{~Hz}\right.$, ${ }^{1} J_{\mathrm{P} 1, \mathrm{Pt} 2}=2090 \mathrm{~Hz},{ }^{2} J_{\mathrm{P} 1, \mathrm{P} 2}=313 \mathrm{~Hz}, \mathrm{P}^{1}$ ) ppm. ${ }^{195} \mathrm{Pt}$ NMR (acetone- $d_{6}, 298 \mathrm{~K}, 86 \mathrm{MHz}$ ), $\delta:-4104\left(\mathrm{Pt}^{1}\right),-4414\left(\mathrm{Pt}^{2}\right) \mathrm{ppm}$.

X-ray structure determinations. Crystal data and other details of the structure analyses are presented in Table S1 (Supporting Information). Suitable crystals for X-ray diffraction studies were obtained by slow diffusion of $n$-hexane into concentrated solutions of the complexes in $2 \mathrm{~mL}$ of $\mathrm{Me}_{2} \mathrm{CO}(4), \mathrm{CH}_{2} \mathrm{Cl}_{2}$.(2, 3, 6 and 7) or $\mathrm{CH}_{2} \mathrm{Cl}_{2}$ plus a few drops of $\mathrm{CH}_{3} \mathrm{CN}$ (8). Crystals were mounted at the end of quartz fibres. The radiation used in all cases was graphite monochromated $\mathrm{MoK} \alpha_{\mathrm{K}}(\lambda=0.71073 \AA)$. X-ray intensity data were collected on an Oxford Diffraction Xcalibur diffractometer. The diffraction frames were integrated and corrected from absorption by using the CrysAlis RED program. ${ }^{74}$ The structures were solved by Patterson and Fourier methods and refined by full-matrix least squares on $F^{2}$ with SHELXL. ${ }^{75}$ All non-hydrogen atoms were assigned anisotropic displacement parameters and refined without positional constraints, except as noted below. All hydrogen atoms were constrained to idealized geometries and assigned isotropic displacement parameters equal to 1.2 times the $U_{\text {iso }}$ values of their attached parent atoms (1.5 times for the methyl hydrogen atoms). For 2, the structure showed packing problems and voids (about $545.4 \AA^{-3}$ ) were present. These voids contain very diffuse electron density, most likely corresponding to crystallization solvent. All the attempts to model it as discrete molecules failed and thus, the SQUEEZE procedure, as implemented in PLATON, ${ }^{76}$ was used to deal with it. As an additional symptom of the deficient packing, the tetrabutyl ammonium cation is badly disordered, with three of its four "legs" disordered over two sets of positions that were refined with 0.5/0.5 partial occupancy. Restrains in the geometry and anisotropic thermal parameters were used of these disordered carbon atoms. For $\mathbf{3} \cdot 1.35 \mathrm{CH}_{2} \mathrm{Cl}_{2}$, one of the tetrabutyl ammonium cations has two of their Bu chains disordered over two positions, and their $\mathrm{C}$ atoms were refined with partial occupancy 0.5. The geometry between these disordered atoms was constrained to sensitive values. One diffuse dichloromethane solvent molecule was found to be disordered over the same area, and their two components were refined with 0.35 partial occupancy. Constrains were used in the geometry of these moieties. For $\mathbf{6}$, the methyl end of the $\mathrm{S}_{2} \mathrm{OEt}$ ligand was disordered over two positions which were refined with 0.5 partial occupancies. For $7 \cdot 0.5 n-\mathrm{C}_{6} \mathrm{H}_{14}$, soft restrains were used in the geometry of the solvent $n$-hexane 
molecule. For 8.1.5 $\mathrm{CH}_{3} \mathrm{CN}$ one of the crystallization acetonitrile moiety lies near an inversion center and is refined with 0.5 partial occupancy. Soft restrains were used in the geometry of this. Full-matrix least-squares refinement of these models against $F^{2}$ converged to final residual indices given in Table S1 (Supporting Information).

\section{ASSOCIATED CONTENT}

\section{Supporting Information}

Table S1. Crystal data and other details of the structure analyses.

Table S2. Selected bond distances $(\AA)$ and angles $\left(^{\circ}\right)$ for complexes $\left[\mathrm{N}^{\mathrm{n}} \mathrm{Bu}_{4}\right]\left[\left(\mathrm{R}_{\mathrm{F}}\right)_{2} \mathrm{Pt}{ }^{\mathrm{II}}(\mu\right.$ $\left.\left.\mathrm{PhS}-\mathrm{PPh}_{2}\right)\left(\mu-\mathrm{PPh}_{2}\right) \mathrm{Pt}^{\mathrm{II}}\left(\mathrm{R}_{\mathrm{F}}\right)_{2}\right] \quad$ (2), $\quad\left[\mathrm{N}^{\mathrm{n}} \mathrm{Bu}_{4}\right]\left[\left(\mathrm{R}_{\mathrm{F}}\right)_{2} \mathrm{Pt}^{\mathrm{II}}\left(\mu-\mathrm{EtOCS}_{2}-\mathrm{PPh}_{2}\right)(\mu-\right.$ $\left.\left.\mathrm{PPh}_{2}\right) \mathrm{Pt}^{\mathrm{II}}\left(\mathrm{R}_{\mathrm{F}}\right)_{2}\right] \cdot 1.35 \mathrm{CH}_{2} \mathrm{Cl}_{2} \quad\left(3 \cdot 1.35 \mathrm{CH}_{2} \mathrm{Cl}_{2}\right)$ and $\left[\mathrm{N}^{\mathrm{n}} \mathrm{Bu}_{4}\right]\left[\left(\mathrm{R}_{\mathrm{F}}\right)_{2} \mathrm{Pt}^{\mathrm{II}}\left(\mu-\mathrm{pymS}-\mathrm{PPh}_{2}\right)(\mu-\right.$ $\left.\left.\mathrm{PPh}_{2}\right) \mathrm{Pt}^{\mathrm{II}}\left(\mathrm{R}_{\mathrm{F}}\right)_{2}\right] \cdot 1.25 \mathrm{Me}_{2} \mathrm{CO}\left(\mathbf{4} \cdot 1.25 \mathrm{Me}_{2} \mathrm{CO}\right)$.

Table S3. Selected bond distances $(\AA)$ and angles $\left(^{\circ}\right)$ for complexes $\left[\mathrm{N}^{\mathrm{n}} \mathrm{Bu}_{4}\right]\left[\left(\mathrm{PPh}_{2} \mathrm{R}_{\mathrm{F}}\right)\left(\mathrm{R}_{\mathrm{F}}\right)_{2} \mathrm{Pt}^{\mathrm{II}}\left(\mu-\mathrm{PPh}_{2}\right) \mathrm{Pt}^{\mathrm{II}}\left(\mathrm{EtOCS}_{2}\right)\left(\mathrm{R}_{\mathrm{F}}\right)\right]$

(6) and $\left[\mathrm{N}^{\mathrm{n}} \mathrm{Bu}_{4}\right]\left[\left(\mathrm{PPh}_{2} \mathrm{R}_{\mathrm{F}}\right)\left(\mathrm{R}_{\mathrm{F}}\right)_{2} \mathrm{Pt}^{\mathrm{II}}\left(\mu-\mathrm{PPh}_{2}\right) \mathrm{Pt}^{\mathrm{II}}(\mathrm{pymS})\left(\mathrm{R}_{\mathrm{F}}\right)\right] \cdot 0.5 n-\mathrm{C}_{6} \mathrm{H}_{14}\left(7 \cdot 0.5 n-\mathrm{C}_{6} \mathrm{H}_{14}\right)$.

Table S4. Selected bond distances $(\AA)$ and angles $\left({ }^{\circ}\right)$ for complex $\left[\left(\mathrm{PPh}_{2} \mathrm{R}_{\mathrm{F}}\right)\left(\mathrm{R}_{\mathrm{F}}\right)\left(\mathrm{CH}_{3} \mathrm{CN}\right) \mathrm{Pt}^{\mathrm{II}}\left(\mu-\mathrm{PPh}_{2}\right) \mathrm{Pt}^{\mathrm{II}}\left(\mathrm{CH}_{3} \mathrm{CN}\right)\left(\mathrm{R}_{\mathrm{F}}\right)_{2}\right] \cdot 1.5 \mathrm{CH}_{3} \mathrm{CN}\left(\mathbf{8} \cdot 1.5 \mathrm{CH}_{3} \mathrm{CN}\right)$.

Crystallographic data in CIF format for compounds 2, 3, 4, 6, 7 and 8.

\section{AUTHOR INFORMATION}

\section{Corresponding Authors:}

*E-mail: cfortuno@unizar.es

*E-mail: p.mastrorilli@poliba.it

\section{ORCID}

Consuelo Fortuño: 0000-0002-6061-0431

Antonio Martín: 0000-0002-4808-574X

Piero Mastrorilli: 0000-0001-8841-458X 
Vito Gallo: 0000-0003-2926-3106

Stefano Todisco: 0000-0001-7863-3105

\section{Notes}

The authors declare no competing financial interest

\section{ACKNOWLEDGMENTS}

This work was supported by the Spanish MINECO/FEDER (Proyect CTQ2015-67461P), and the Gobierno de Aragón and Fondo Social Europeo (Grupo Consolidado E21: Química Inorgánica y de los Compuestos Organometálicos). 


\section{REFERENCES AND NOTES}

(1) Vigalok, A. Accounts of Chemical Research 2015, 48, 238-247.

(2) Canty, A. J. Dalton Transactions 2009, 10409-10417.

(3) Powers, D. C.; Ritter, T. Accounts of Chemical Research 2012, 45, 840850.

(4) Mirica, L. M.; Khusnutdinova, J. R. Coordination Chemistry Reviews 2013, 257, 299-314.

(5) Labinger, J. A.; Bercaw, J. E. In Higher Oxidation State Organopalladium and Platinum Chemistry; Canty, A. J., Ed. 2011; Vol. 35, p 29-59.

(6) Canty, A. J.; Sharma, M. In Higher Oxidation State Organopalladium and Platinum Chemistry; Canty, A. J., Ed. 2011; Vol. 35, p 111-127.

(7) Hickman, A. J.; Sanford, M. S. Nature 2012, 484, 177-185.

(8) Labinger, J. A. Chemical Reviews 2017, 117, 8483-8496.

(9) Alonso, E.; Casas, J. M.; Cotton, F. A.; Feng, X. J.; Forniés, J.; Fortuño, C.; Tomás, M. Inorganic Chemistry 1999, 38, 5034-5040.

(10) Alonso, E.; Casas, J. M.; Forniés, J.; Fortuño, C.; Martín, A.; Orpen, A. G.; Tsipis, C. A.; Tsipis, A. C. Organometallics 2001, 20, 5571-5582.

(11) Ara, I.; Chaouche, N.; Forniés, J.; Fortuño, C.; Kribii, A.; Tsipis, A. C. Organometallics 2006, 25, 1084-1091.

(12) Ara, I.; Forniés, J.; Fortuño, C.; Ibáñez, S.; Martín, A.; Mastrorilli, P.; Gallo, V. Inorganic Chemistry 2008, 47, 9069-9080. 
(13) Arias, A.; Forniés, J.; Fortuño, C.; Martín, A.; Latronico, M.; Mastrorilli, P.; Todisco, S.; Gallo, V. Inorganic Chemistry 2012, 51, 12682-12696.

(14) Forniés, J.; Fortuño, C.; Ibáñez, S.; Martín, A. Inorganic Chemistry 2006, 45, 4850-4858.

(15) Forniés, J.; Fortuño, C.; Ibáñez, S.; Martín, A.; Tsipis, A. C.; Tsipis, C. A. Angewandte Chemie-International Edition 2005, 44, 2407-2410.

(16) Arias, A.; Forniés, J.; Fortuño, C.; Martín, A.; Mastrorilli, P.; Todisco, S.; Latronico, M.; Gallo, V. Inorganic Chemistry 2013, 52, 5493-5506.

(17) Arias, A.; Forniés, J.; Fortuño, C.; Ibáñez, S.; Martín, A.; Mastrorilli, P.; Gallo, V.; Todisco, S. Inorganic Chemistry 2013, 52, 11398-11408.

(18) Crumpton-Bregel, D. M.; Goldberg, K. I. Journal of the American Chemical Society 2003, 125, 9442-9456.

(19) Dubinsky-Davidchik, I.; Goldberg, I.; Vigalok, A.; Vedernikov, A. N. Angewandte Chemie-International Edition 2015, 54, 12447-12451.

(20) Yahav-Levi, A.; Goldberg, I.; Vigalok, A.; Vedernikov, A. N. Chemical Communications 2010, 46, 3324-3326.

(21) Nielsen, M. C.; Lyngvi, E.; Schoenebeck, F. Journal of the American Chemical Society 2013, 135, 1978-1985.

(22) Crosby, S. H.; Clarkson, G. J.; Rourke, J. P. Organometallics 2012, 31, 7256-7263.

(23) Bowes, E. G.; Pal, S.; Love, J. A. Journal of the American Chemical Society 2015, 137, 16004-16007. 
(24) Zucca, A.; Maidich, L.; Canu, L.; Petretto, G. L.; Stoccoro, S.; Cinellu, M. A.; Clarkson, G. J.; Rourke, J. P. Chemistry-a European Journal 2014, 20, 55015510 .

(25) Grice, K. A.; Scheuermann, M. L.; Goldberg, K. I. In Higher Oxidation State Organopalladium and Platinum Chemistry; Canty, A. J., Ed. 2011; Vol. 35, p 127.

(26) Scheuermann, M. L.; Luedtke, A. T.; Hanson, S. K.; Fekl, U.; Kaminsky, W.; Goldberg, K. I. Organometallics 2013, 32, 4752-4758.

(27) Zhao, S.-B.; Cui, Q.; Wang, S. Organometallics 2010, 29, 998-1003.

(28) McBee, J. L.; Tilley, T. D. Organometallics 2009, 28, 3947-3952.

(29) Sangtrirutnugul, P.; Tilley, T. D. Organometallics 2008, 27, 2223-2230.

(30) West, N. M.; White, P. S.; Templeton, J. L.; Nixon, J. F. Organometallics 2009, 28, 1425-1434.

(31) Shaw, P. A.; Phillips, J. M.; Clarkson, G. J.; Rourke, J. P. Dalton Transactions 2016, 45, 11397-11406.

(32) Shaw, P. A.; Clarkson, G. J.; Rourke, J. P. Organometallics 2016, 35, 3751-3762.

(33) Gallo, V.; Latronico, M.; Mastrorilli, P.; Nobile, C. F.; Ciccarella, G.; Englert, U. European Journal of Inorganic Chemistry 2006, 2634-2641.

(34) Hossain, M. M.; Lin, H. M.; Zhu, J.; Lin, Z. Y.; Shyu, S. G. Organometallics 2006, 25, 440-446.

(35) Oh, S.; Lee, Y. Organometallics 2016, 35, 1586-1592. 
(36) King, J. D.; Mays, M. J.; Mo, C. Y.; Solan, G. A.; Conole, G.; McPartlin, M. Journal of Organometallic Chemistry 2002, 642, 227-236.

(37) Alonso, E.; Forniés, J.; Fortuño, C.; Martín, A.; Orpen, A. G. Organometallics 2001, 20, 850-859.

(38) Alonso, E.; Forniés, J.; Fortuño, C.; Martín, A.; Orpen, A. G. Organometallics 2003, 22, 2723-2728.

(39) Forniés, J.; Fortuño, C.; Gil, R.; Martín, A. Inorganic Chemistry 2005, 44, 9534-9541.

(40) Alonso, E.; Forniés, J.; Fortuño, C.; Tomás, M. Journal of the Chemical Society-Dalton Transactions 1995, 3777-3784.

(41) Mastrorilli, P.; Todisco, S.; Bagno, A.; Gallo, V.; Latronico, M.; Fortuño, C.; Gudat, D. Inorganic Chemistry 2015, 54, 5855-5863.

(42) Mastrorilli, P. European Journal of Inorganic Chemistry 2008, 48354850.

(43) Boag, N. M.; Browning, J.; Crocker, C.; Goggin, P. L.; Goodfellow, R. J.; Murray, M.; Spencer, J. L. Journal of Chemical Research-S 1978, 228-\&.

(44) Messbauer, B.; Meyer, H.; Walther, B.; Heeg, M. J.; Rahman, A.; Oliver, J. P. Inorganic Chemistry 1983, 22, 272-277.

(45) Zschunke, A.; Meyer, H.; Heidlas, I.; Messbauer, B.; Walther, B.; Schadler, H. D. Zeitschrift Fur Anorganische Und Allgemeine Chemie 1983, 504, 117 127.

(46) Gallo, V.; Latronico, M.; Mastrorilli, P.; Nobile, C. F.; Polini, F.; Re, N.; Englert, U. Inorganic Chemistry 2008, 47, 4785-4795. 
(47) Rahman, A.; Ceccarelli, C.; Oliver, J. P.; Messbauer, B.; Meyer, H.; Walther, B. Inorganic Chemistry 1985, 24, 2355-2359.

(48) Anderson, D. M.; Ebsworth, E. A. V.; Stephenson, T. A.; Walkinshaw, M. D. Journal of the Chemical Society-Dalton Transactions 1982, 2343-2351.

(49) Wagner, K. P.; Hess, R. W.; Treichel, P. M.; Calabrese, J. C. Inorganic Chemistry 1975, 14, 1121-1127.

(50) Chaouche, N.; Forniés, J.; Fortuño, C.; Kribii, A.; Martín, A.; Karipidis, P.; Tsipis, A. C.; Tsipis, C. A. Organometallics 2004, 23, 1797-1810.

(51) Chaouche, N.; Forniés, J.; Fortuño, C.; Kribii, A.; Martín, A. Journal of Organometallic Chemistry 2007, 692, 1168-1172.

(52) Forniés, J.; Fortuño, C.; Ibáñez, S.; Martín, A. Inorganic Chemistry 2008, 47, 5978-5987.

(53) Falvello, L. R.; Forniés, J.; Fortuño, C.; Martín, A.; Martínez-Sarinena, A. P. Organometallics 1997, 16, 5849-5856.

(54) Ghavale, N.; Wadawale, A.; Dey, S.; Jain, V. K. Journal of Organometallic Chemistry 2010, 695, 1237-1245.

(55) Usón, R.; Forniés, J.; Falvello, L. R.; Tomás, M.; Ara, I.; Usón, I. Inorganica Chimica Acta 1995, 232, 35-42.

(56) Cornock, M. C.; Gould, R. O.; Jones, C. L.; Owen, J. D.; Steele, D. F.; Stephenson, T. A. Journal of the Chemical Society-Dalton Transactions 1977, 496-501.

(57) Martínez-Salvador, S.; Forniés, J.; Martín, A.; Menjón, B.; Usón, I. Chemistry-a European Journal 2013, 19, 324-337.

(58) de Castro, V. D.; de Lima, G. M.; Porto, A. O.; Siebald, H. G. L.; de Souza, J. D.; Ardisson, J. D.; Ayala, J. D.; Bombieri, G. Polyhedron 2004, 23, 63-69. 
(59) Bonnington, K. J.; Jennings, M. C.; Puddephatt, R. J. Organometallics 2008, 27, 6521-6530.

(60) Quintal, S. M. O.; Nogueira, H. I. S.; Félix, V.; Drew, M. G. B. Journal of the Chemical Society-Dalton Transactions 2002, 4479-4487.

(61) Forniés, J.; Fortuño, C.; Gómez, M. A.; Menjón, B. Organometallics 1993, 12, 4368-4375.

(62) At low T, NOE contacts have the same sign of exchange cross peaks. In this experiment we discriminated exchange cross peaks from NOE contacts by comparing the ${ }^{1} \mathrm{H}$ EXSY data with ${ }^{1} \mathrm{H}$ COSY spectrum at $198 \mathrm{~K}$.

(63) Rivada-Wheelaghan, O.; Rosello-Merino, M.; Díez, J.; Maya, C.; LópezSerrano, J.; Conejero, S. Organometallics 2014, 33, 5944-5947.

(64) Ariafard, A.; Hyland, C. J. T.; Canty, A. J.; Sharma, M.; Yates, B. F. Inorganic Chemistry 2011, 50, 6449-6457.

(65) Shaw, P. A.; Phillips, J. M.; Newman, C. P.; Clarkson, G. J.; Rourke, J. P. Chemical Communications 2015, 51, 8365-8368.

(66) Abo-Amer, A.; Boyle, P. D.; Puddephatt, R. J. Inorganic Chemistry Communications 2015, 61, 193-196.

(67) Crosby, S. H.; Thomas, H. R.; Clarkson, G. J.; Rourke, J. P. Chemical Communications 2012, 48, 5775-5777.

(68) Archambault, C.; Bender, R.; Braunstein, P.; DeCian, A.; Fischer, J. Chemical Communications 1996, 2729-2730.

(69) Cabeza, J. A.; del Río, I.; Riera, V.; García-Granda, S.; Sanni, S. B. Organometallics 1997, 16, 1743-1748.

(70) Heyn, R. H.; Gorbitz, C. H. Organometallics 2002, 21, 2781-2784. 
(71) Albinati, A.; Filippi, V.; Leoni, P.; Marchetti, L.; Pasquali, M.; Passarelli, V. Chemical Communications 2005, 2155-2157.

(72) Ara, I.; Forniés, J.; Ibáñez, S.; Mastrorilli, P.; Todisco, S.; Gallo, V. Dalton Transactions 2016, 45, 2156-2171.

(73) Uson, R.; Fornies, J. Advances in Organometallic Chemistry 1988, 28, 219-297.

(74) CrysAlisRED; Program for X-ray CCD camera data reduction, Version 1.171.32.19, Oxford Diffraction Ltd.: Oxford, UK, 2008.

(75) Sheldrick, G. M. Acta Crystallographica Section C-Structural Chemistry 2015, 71, 3-8.

(76) Spek, A. L. Acta Crystallographica Section D-Biological Crystallography 2009, 65, 148-155. 
“For Table of Contents Only"

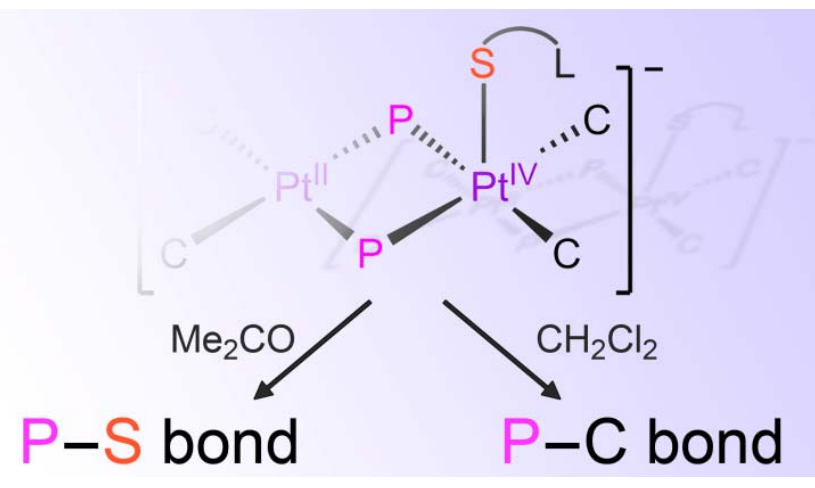

Reactivity of the $\mathrm{Pt}(\mathrm{III}), \mathrm{Pt}(\mathrm{III})$ complex $\left[\left(\mathrm{C}_{6} \mathrm{~F}_{5}\right)_{2} \mathrm{Pt}^{\mathrm{III}}\left(\mu-\mathrm{PPh}_{2}\right)_{2} \mathrm{Pt}^{\mathrm{III}}\left(\mathrm{C}_{6} \mathrm{~F}_{5}\right)_{2}\right](P t-P t)$ (1) with didentate S-based anions $\left(\mathrm{L}^{\wedge} \mathrm{S}^{-}\right)$was found dependent on the reaction solvent. The reductive coupling between the $\mathrm{PPh}_{2}$ and $\mathrm{L} \wedge \mathrm{S}$ (acetone) or $\mathrm{C}_{6} \mathrm{~F}_{5}$ (dichloromethane) groups produces $\mathrm{Pt}(\mathrm{II})$ complexes with new $\mathrm{Ph}_{2} \mathrm{P}-\mathrm{SL}$ (acetone) or $\mathrm{Ph}_{2} \mathrm{P}-\mathrm{C}_{6} \mathrm{~F}_{5}$ (dichloromethane) ligands. 